\title{
أبو حمحل عبدالله بن حمحد الأزدي الصحاري الطبيب حياته , ومنهجه العلمي في المعرفة
}

\author{
إعداد \\ د. زيني بن طلال بن الحازمي \\ أستاذ مساعد ـ قسم العلوم الاجتماعية \\ جامعة الملك عبدالعزيز - جدة العئ \\ المملكة العربية السعودية
}

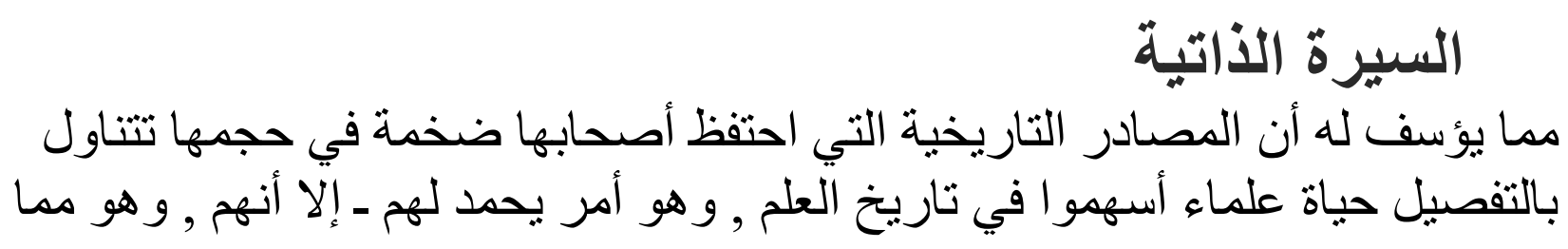


يستغرب لله , تتاسو ا أبا تحمد الصحاري وجهوده العلمية , ولم يكن نصيبه من كل هذا

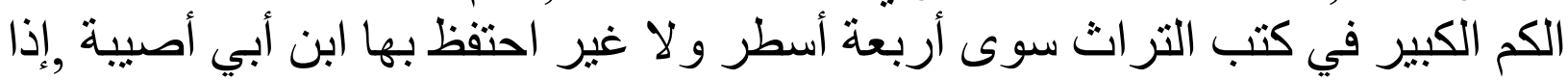

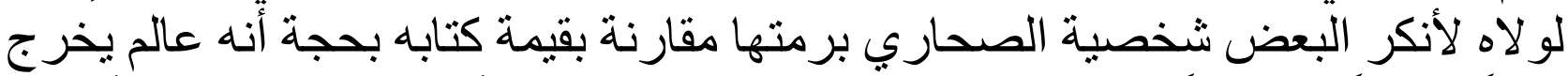

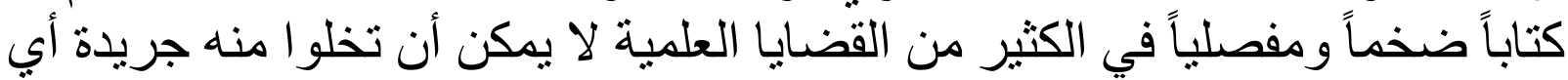

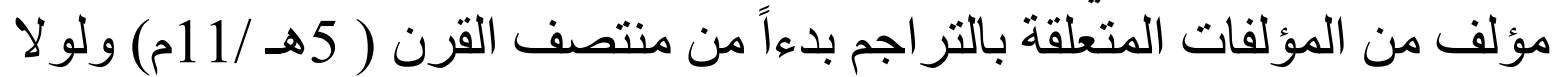
الثذر ات المتفرقة في كتاب الصحاري عن محطات تتعلق بسيرته لوجدنا من بفترض الته

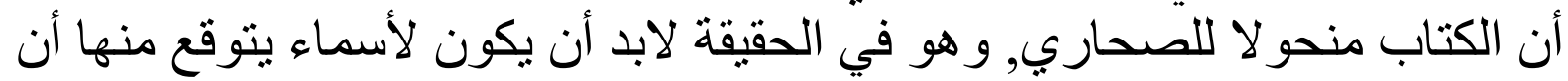

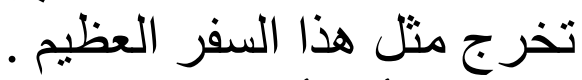
يقول ابن أبي أصبيعة: (( وهو أبو حمح عبدالله بن محمد الأزدي .... ويعرف بابن بابن الذهبي .. أحد المقنين بضاعة الطب و مطالعة كتب الفلاسفة , وكان كلفاً بضاعة الكيمياء ر مجتهداً

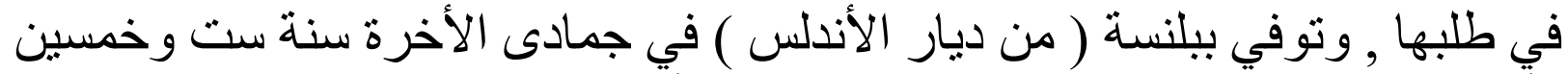

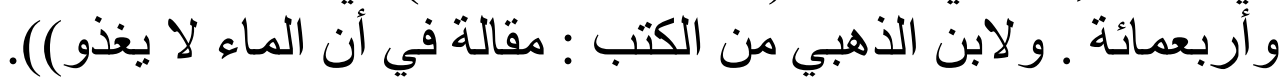

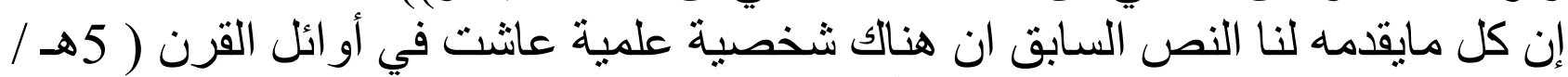

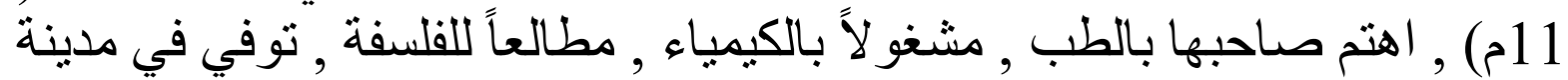

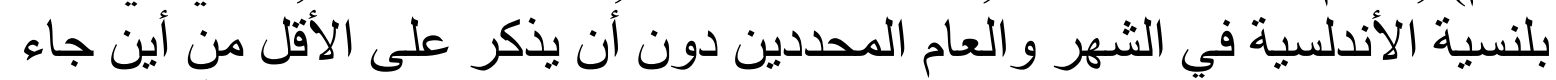

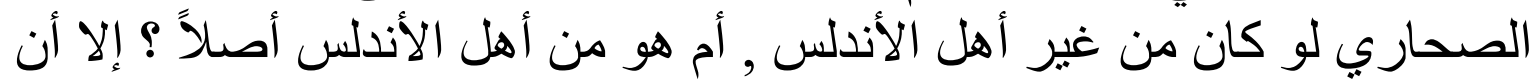

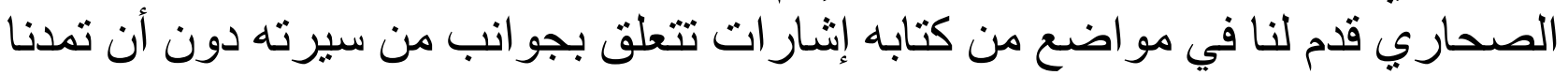

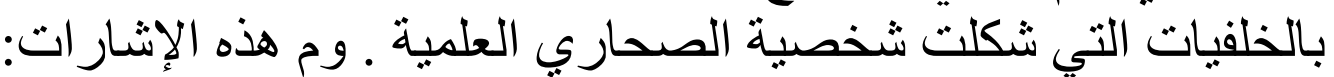

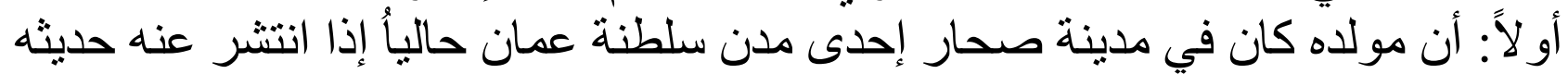

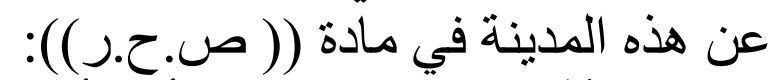

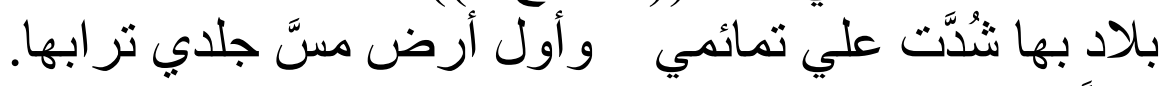

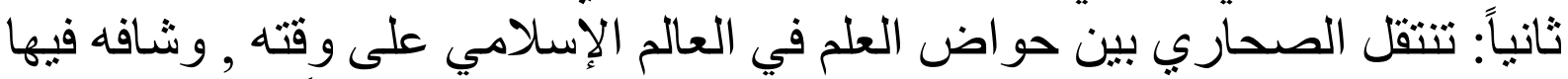

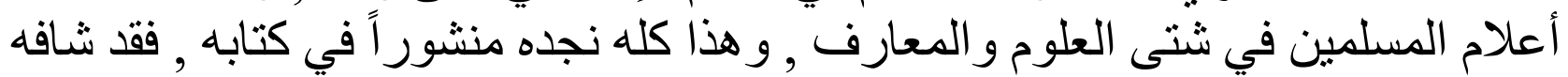

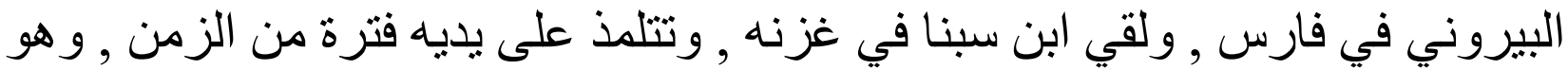

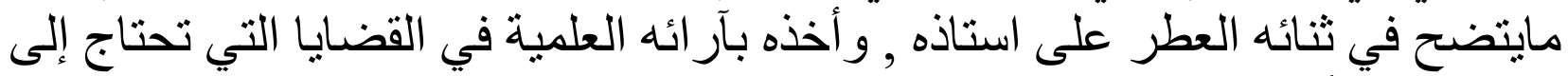

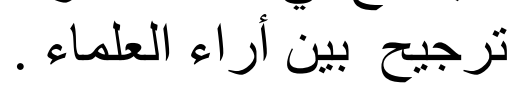

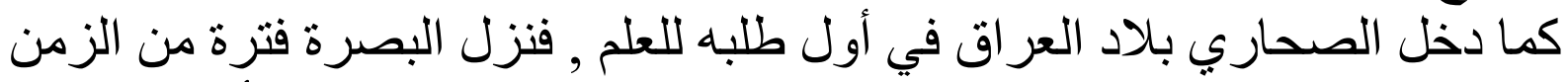

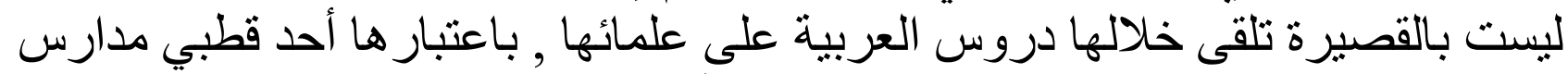

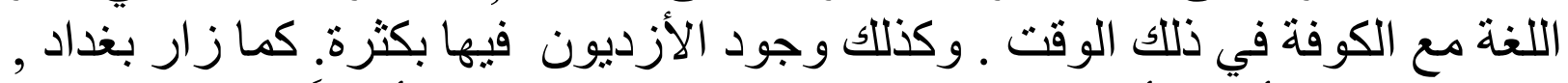

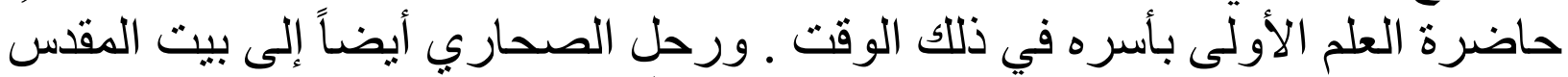

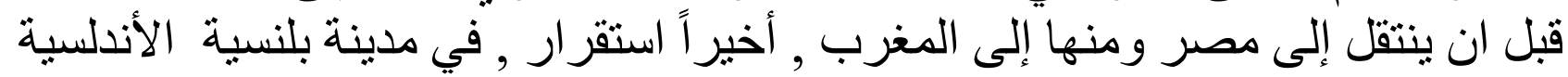
حتى وفاته بها سنة

مؤلقاته: مقنة:

حقيقة أن الفقر المدفع المتعلق بتفاصيل سيرة حياة الصحاري يسيري أيضاً على إنتاجه

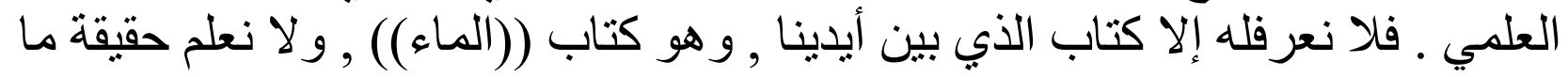


إذا كان للصحاري كتب أخرى لم يذكر ها لعدم صلتها بموضوع الكتاب , أم أنه فعلاً لم يصنف إلا هذا الكتاب فقط.

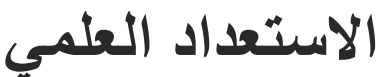

كانت الإحاطة بالمفاهيم الثائعة في المجتمع مصدر اً أو مادة علمية للنقا ، وهو مـا لئا

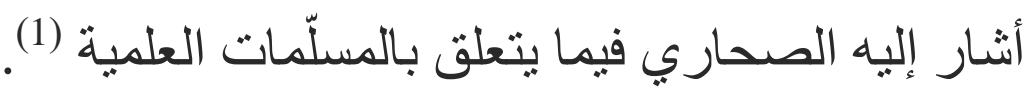

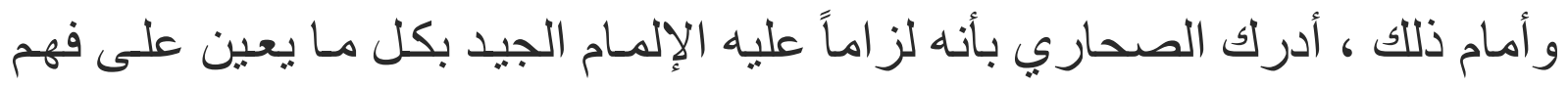

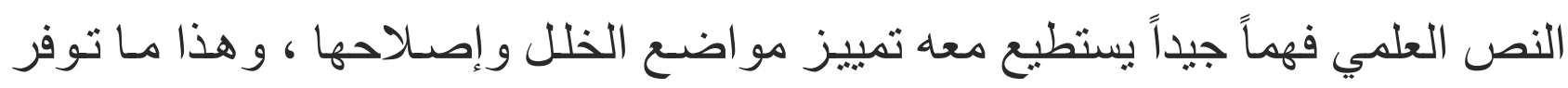

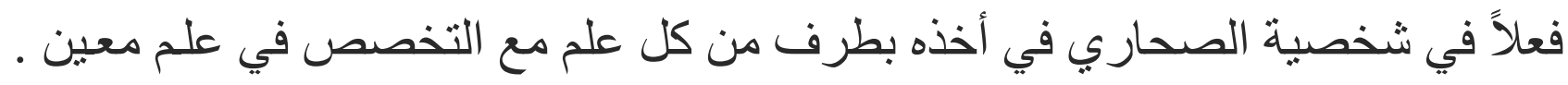

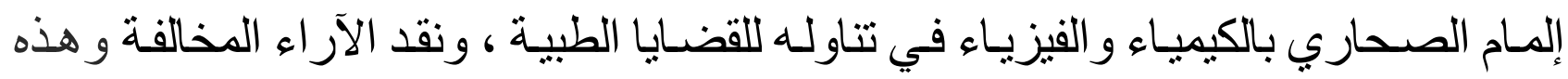

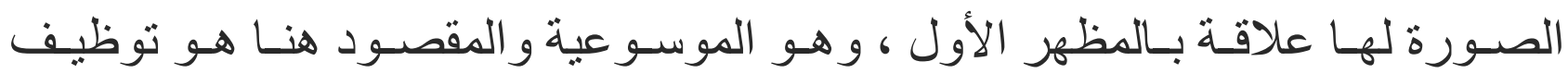

المعلومات المكتسبة من العلوم الأخرى في مناقثنة الآر اء الخاصة بعلم من العلوم (2).

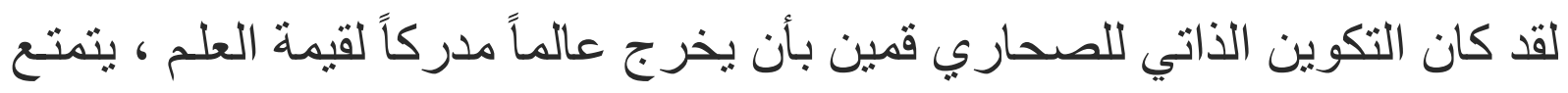

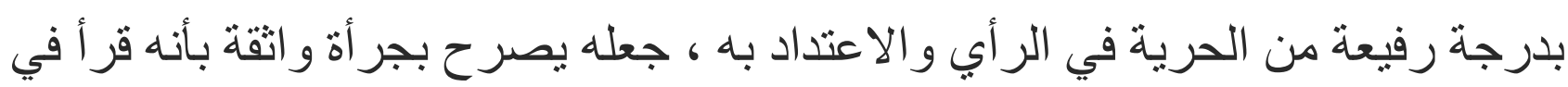

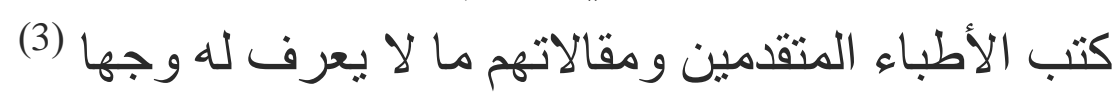

معالم المنْهَج العِلميّ للصحاري

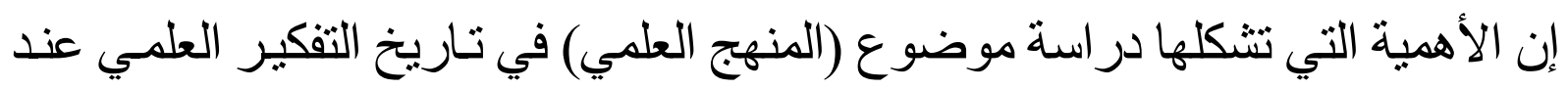

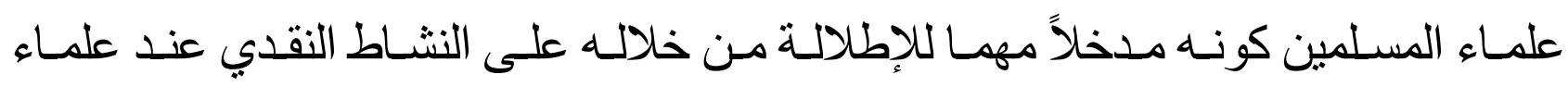

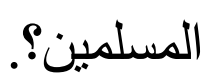

كما إن موضوع المنهج العلمي و التزراث يكتسب أهميـة خاصـة؛ لأنه كان ومـاز ال

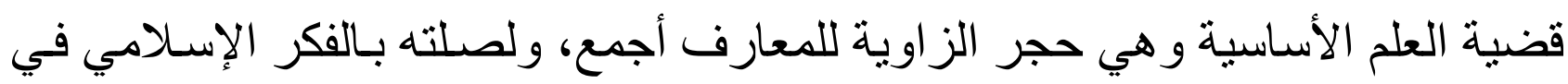

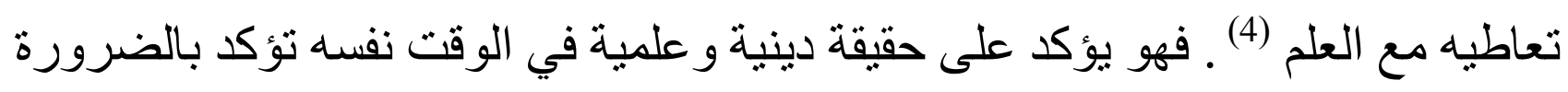
الإيمان بالله، وذلك من خـلال مجموعة من المسلمات (5) التي ينطلق منها العـالِّ ويتم

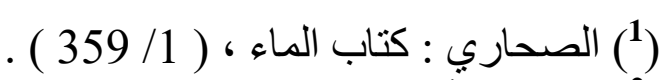

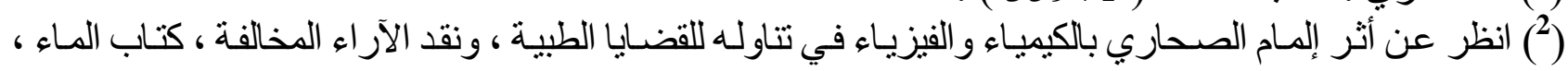

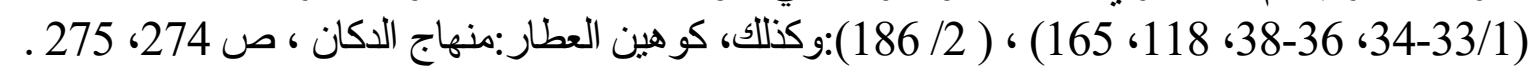

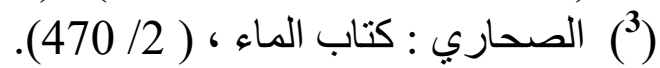

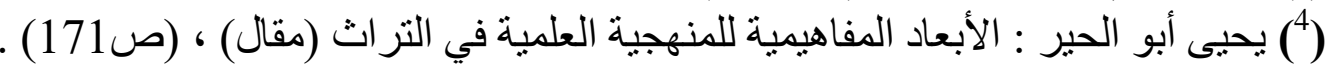

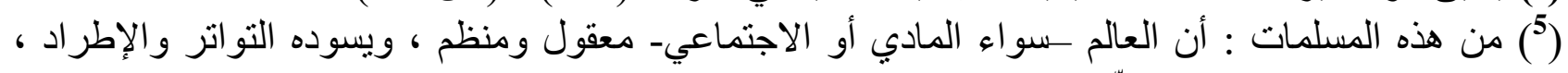

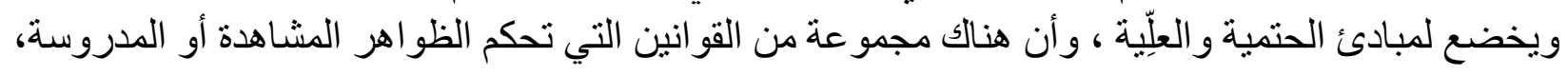


الوصول إليها من خلال عدة خطوات (6) تشكل في مجمو عها (المنهج العلمي) ـ وهذا

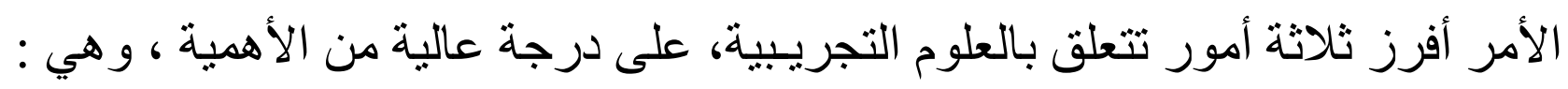

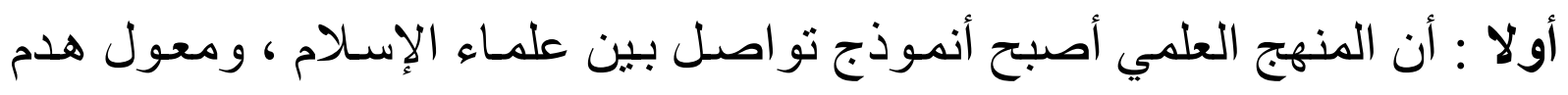

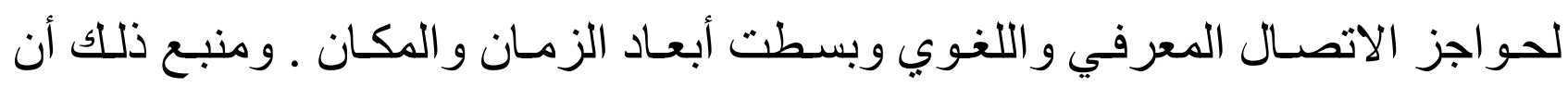

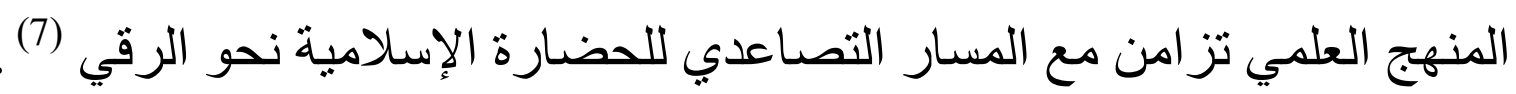

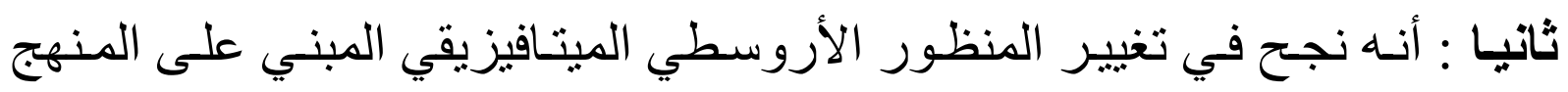
العقلي الاستنباطي و القياس الصوري إلى منظور منهجي جديد يحوي في طياته عناصر

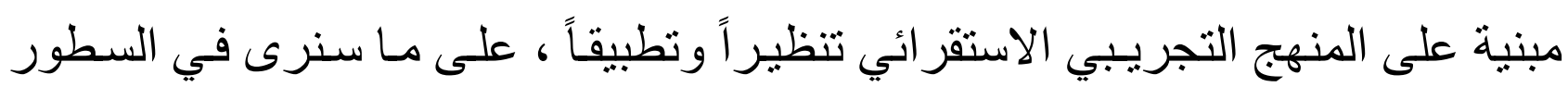
القادمة .

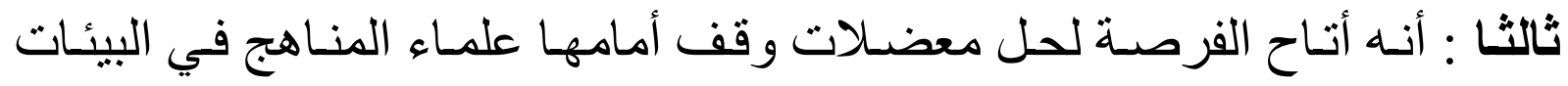
العلمية الناشئة ، أو حتى المعاصرة ، موقف المتفرج ـ و وهي تتعلق بفهم موضع (مبدأ

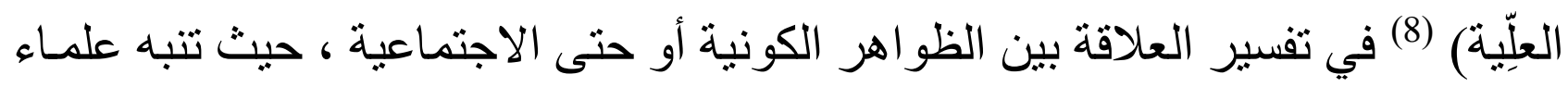

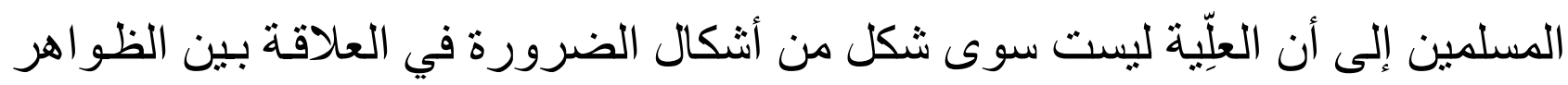

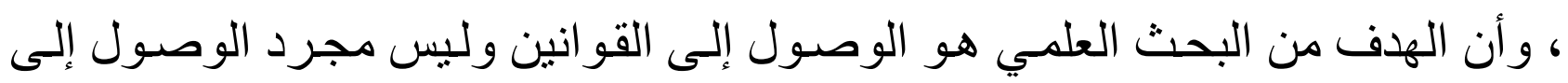

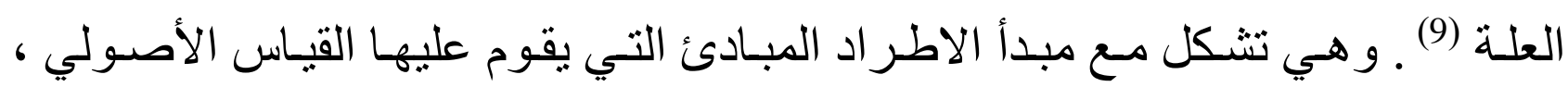
وكذلك المنهج الاستقرائي، على نحو ما سيمر معنا فيما بعد .

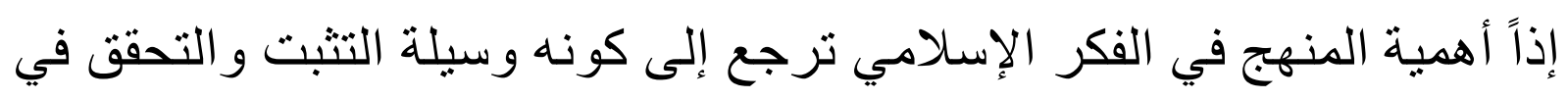

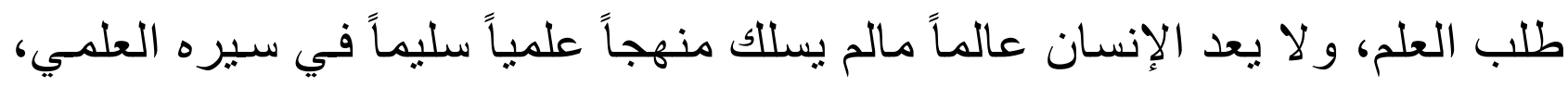

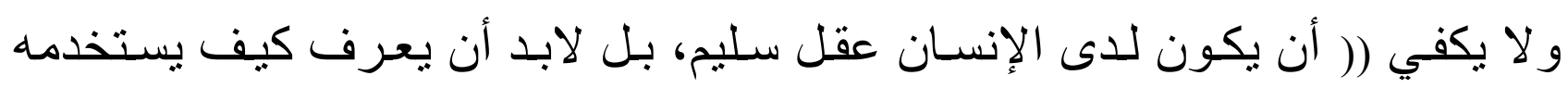

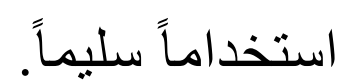

وأنه يمكن للعقل البشري الوصول إلى هذه القو انين ـوللتوسع انظر : محمود قاسم : المنطق الحديث ومناهج

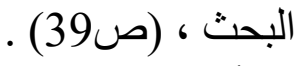

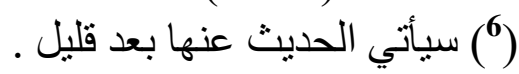

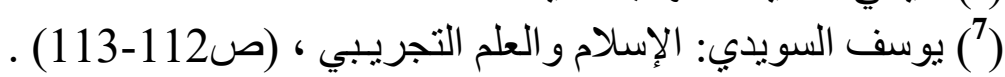

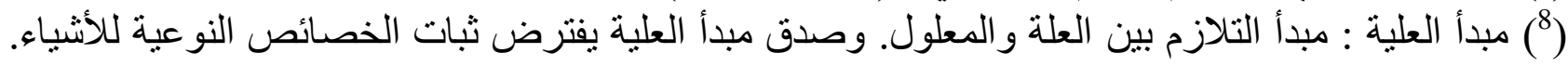

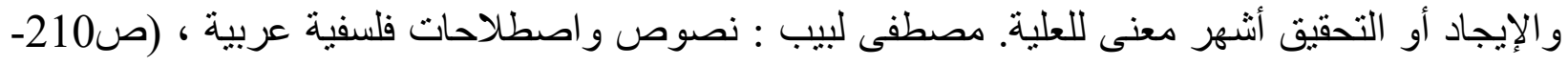

(9) نبيل السمالوطي ، إثكاليات المنهج العلمي (مقال) ، (ص30) . 
ونظر ال اهتمـام الإسـام البالغ بمنهج نوثيق الأخبار ، و عنايته بمنهج القياس في

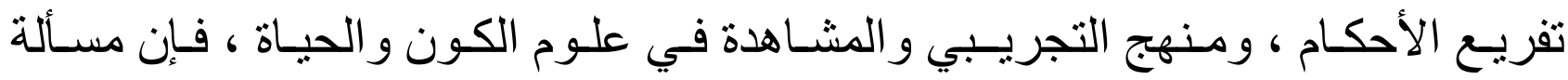

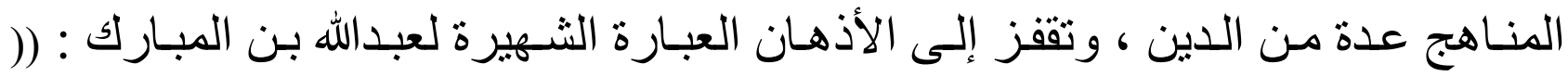

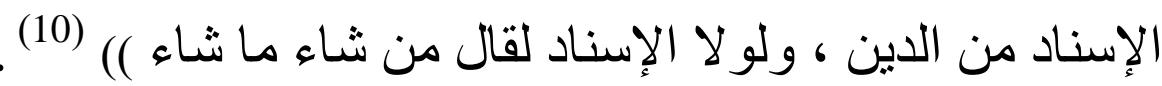

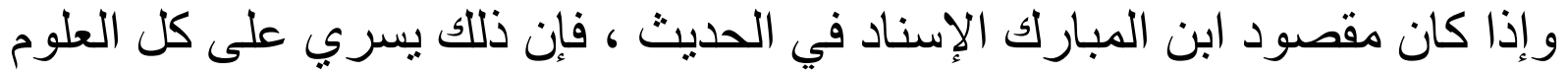
في الإسلام وكأنها تعبر عن قاعدة مهمة في المنهج العلمي ، وهي التثبت الصـادق في

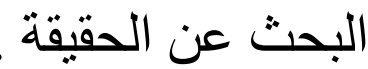

و أفضى تتبع مصطلح (المنهج) في مؤلفات علماء المسلمين في العلوم التجريـية ، على وجه الخصوص ، إلى أن أقدم ذكر لهذا الدصطلح كان عند ابن الهيثم عندما قال :

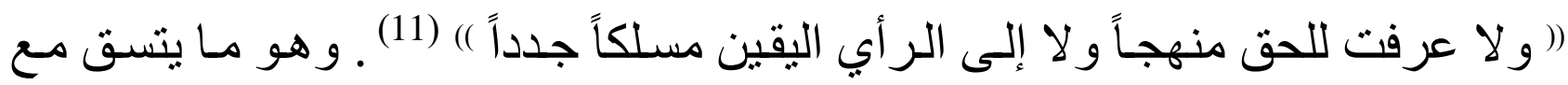
تعريف عبدالرحمن بيومي للمنهج بقوله : ( هو الطريق المؤدي إلى الكثف عن الحقيقة

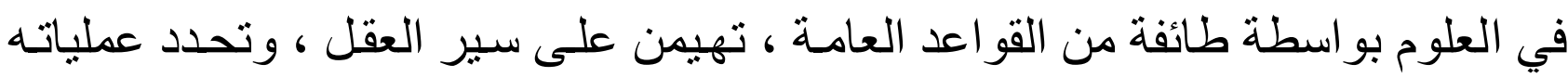
الفكرية حتى يصل إلى نتيجة معلومة ) (12). على أن علماء المسلمين قد عبروا عن المنهج أيضا بالأصول و القو اعد ـ و عليه فقد وصفت بعض الأصول الخاصة بالبحث في الحديث و الفقه و التفسير وعلم الكلام ، وهو

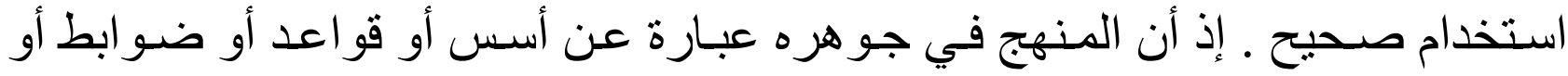
أصول تحكم عنصري العمل العلمي : الباحث، والموضوع، والأصول من (( حيث أنها

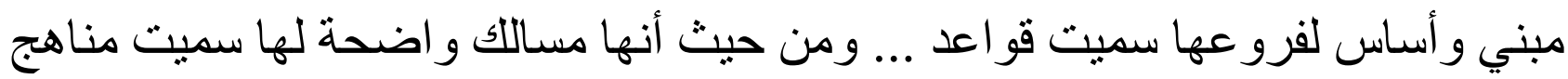
)(13) . بل يرى البعض (14) بأن كلمة (المنهج) قد أدت المعنى المر اد منها وزيادة ، وأن التمسك بالمصطلحات القديمة يعد ضربا من التنطع ـ وهذا الأمر لا يستقيم على الأقل

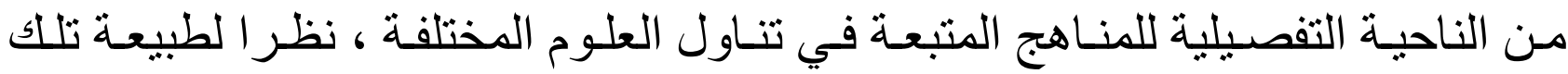
العلوم ، إذ يترتب على بعضها حكماً قاطعاً مبنياً على ذلك المنهج ، فلابد إذاً من التمييز

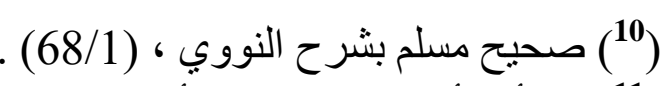

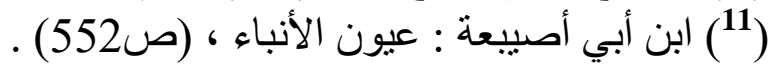

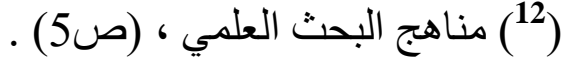

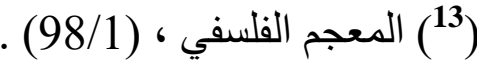
(14) علي الظاهر : منهج البحث الأدبي ، (ص14) . 
مـن حيـث المسـيات بـين هذا المـنهج أو ذاك عند الاستعانة بهـا ، على أن مصـلح (المنهج) بمعناه الاصطلاحي لم يعرف خارج بيئة الإسـلام إلا في القرن (السـابع عشر

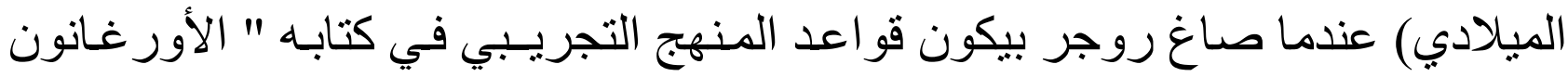
الجديد Novam organum " عام 1620م ، ومصطلح (المنهج) المقصود هنا هو : (المنهج

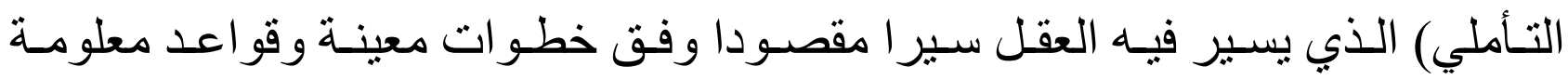
ومحددة سلفا ، وليس (المنهج التلقائي) الذي يسير فيه العقل سير ا فطريـا بـلا قو اعد إعداع مسبقة يتكئ عليها ـ فهو و إن كان موصلا للحقيقة إلا أنـه ليس المقصود بالدراسـة عند

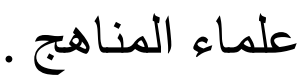
أمـا مدلول كلمـة (البحث) الاصطلاحي من خـلال معناهـا اللغوي، فهو : طلب الحقيقة وتقصيها ومحاولـة الوصسول إليها. ونقر أ في رسـالة أبي حيان التوحيدي في التي

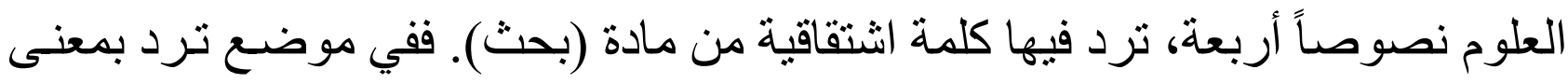
(المحاورة و المفاتثة) (15)، وفي موضع آخر بمعنى (الباحث عن الحكمة) (16)، وفي

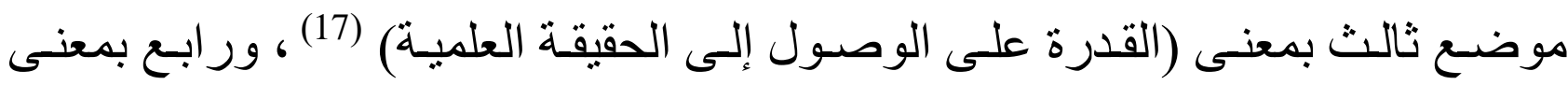
(الباحث المستتير بعقله للوصول إلى مبتغاه) (18) ـو على ذللك فإن مصطلح (البحث)

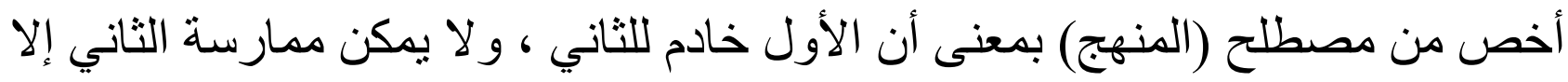

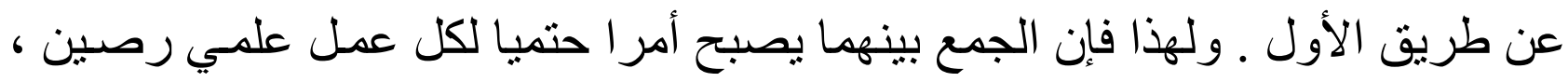

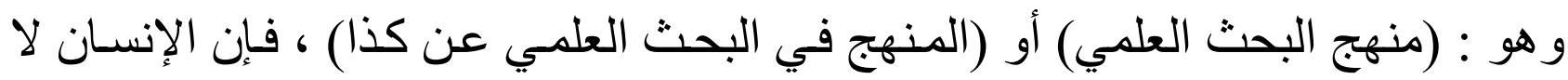

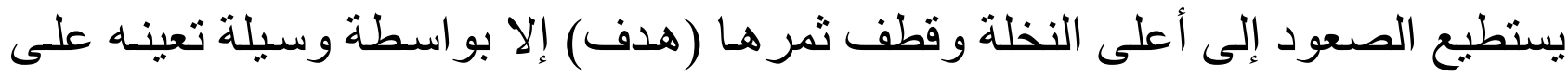
ذلك (الطريقة) ، فالبحث عن الهدف وبلو غه لا يكون إلا عن طريق منهج و اضح وسليم

ولم يجد العلماء في الحضـارة الإسـلامية صدعوبة تذكر في بنـاء المـهـج العلمي و تطويره وتطبيقه و الالتز ام بـه في بحوثهم و أعمـالهم العلميـة ، لأن 
مبادئ قو اعد و أخلاقيات هذا المنهج في مجمو عها جزء من فكر هم الإسـلامي

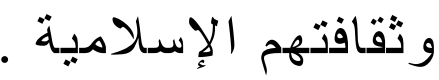

فعلى الرغم من معرفة علماء المسلمين لطبيعة البحث العلمي في العلوم التجريـيبة ولعناصره و أركانه وشروطه وخطو اته، و إدر اكهم لضرورة اتباع منهج علمي تجريبي

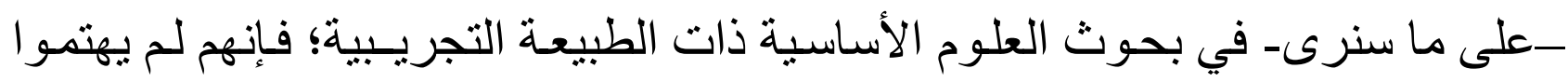

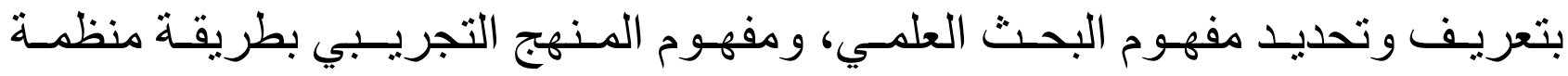
ومستقلة ، على النحو الذي نجده في كتابات البحث العلمي ومناهجه المعاصرة .

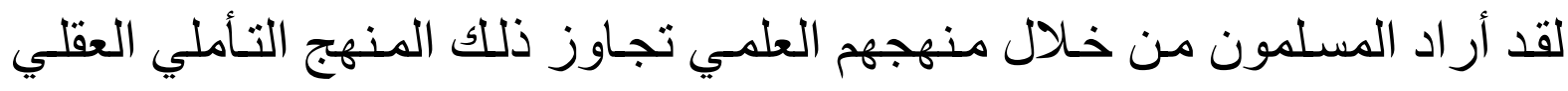

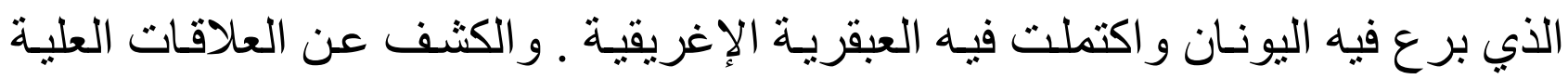
(السبيية) التي تقوم بين الظو اهر بعضها لبعض ، بهدف وضع القو انين التي تفسرها ـ التهن

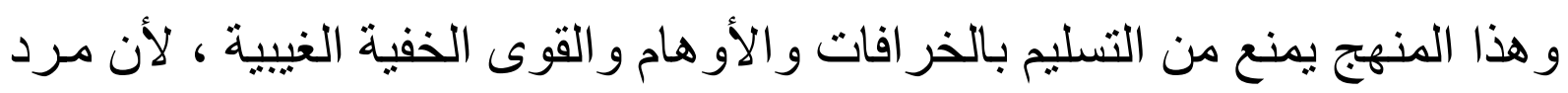

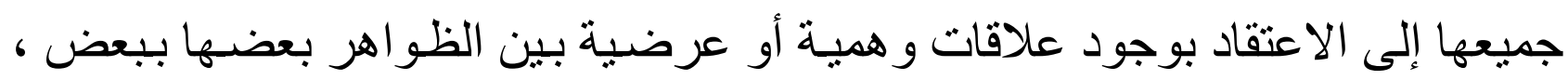

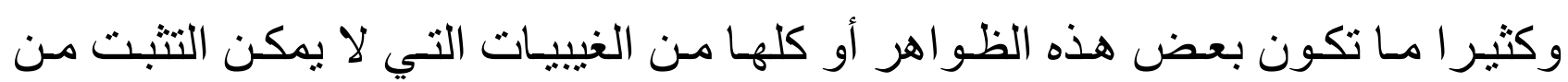

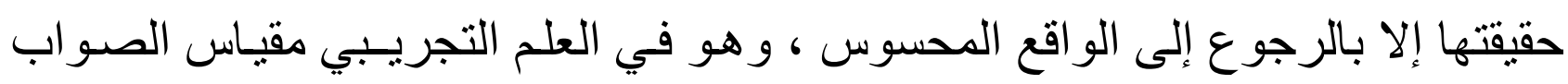

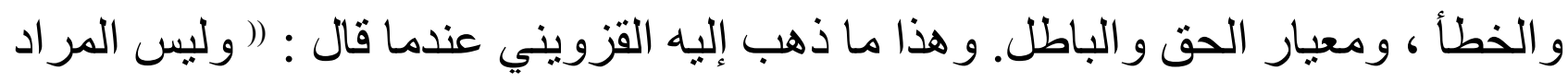

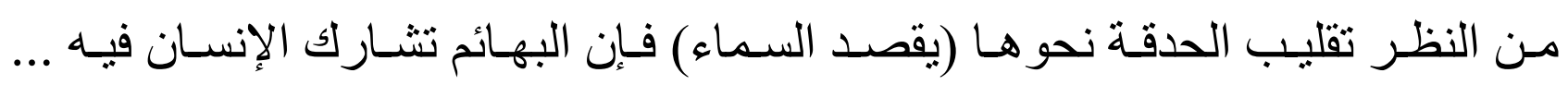

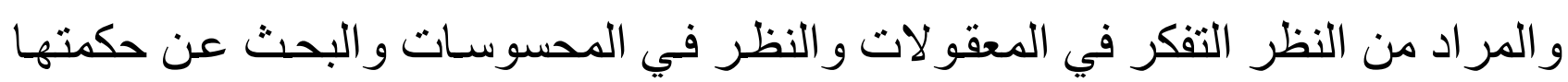
وتصاريفها يظهر له حقائقها.

ولما كان الثثك وثيق الارتباط بالمنهج العلمي عند علمـاء المسلمين، إذ به ينوقف

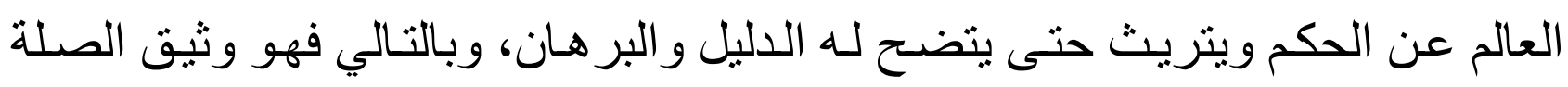

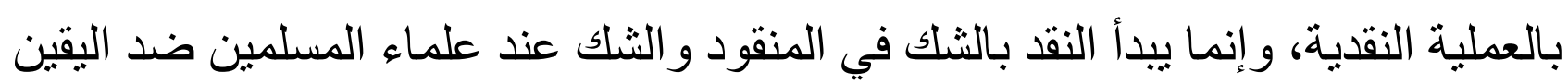

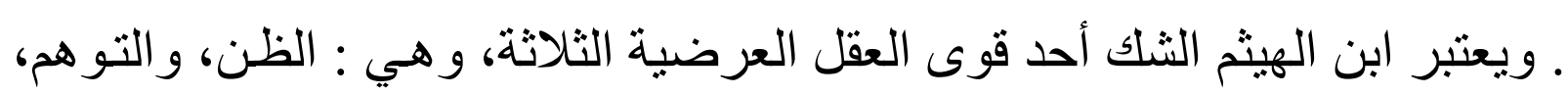

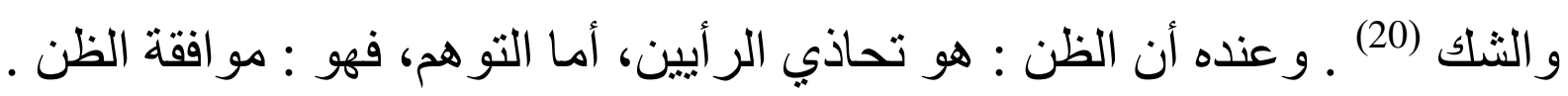

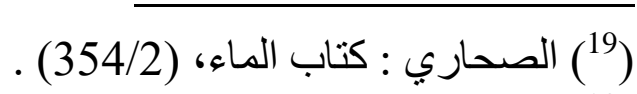

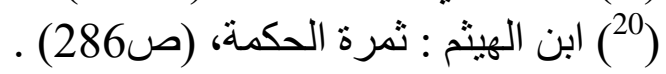


فإذا كان غرض ابن الهيثم من وراء شكوكه على بطليموس حل هذه الثنكوك فقط،

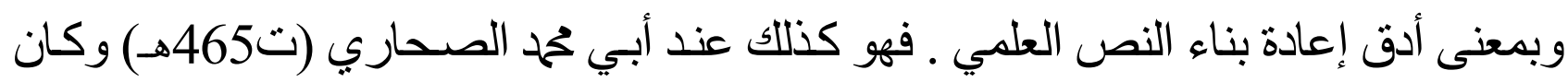

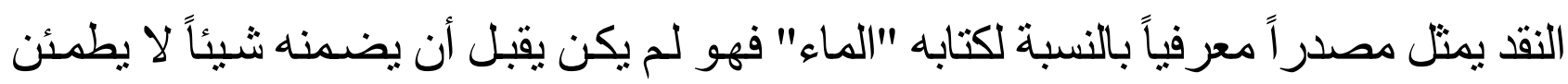

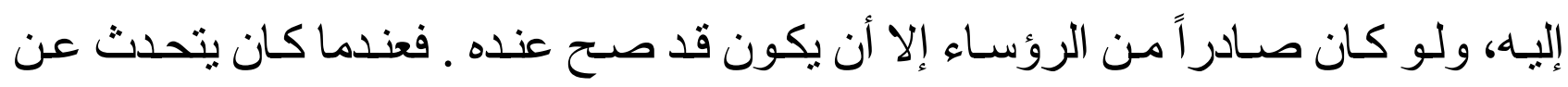

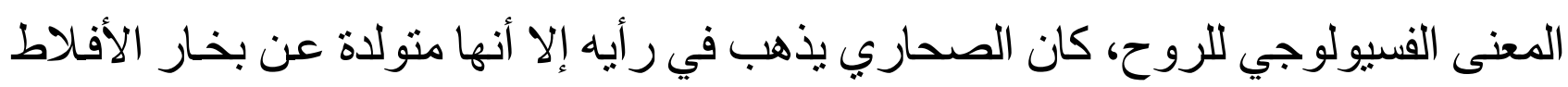

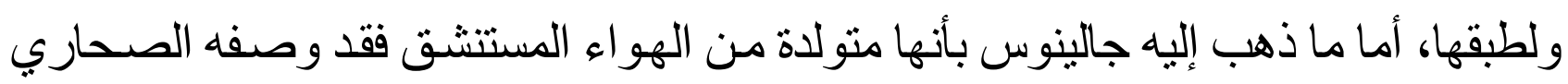

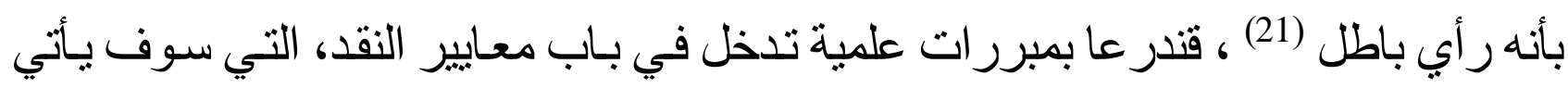

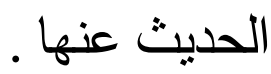

وتمثنل عملية التصحيح و التنقيح و إعـادة بنـاء النص عند الصحاري عملاً علمياً

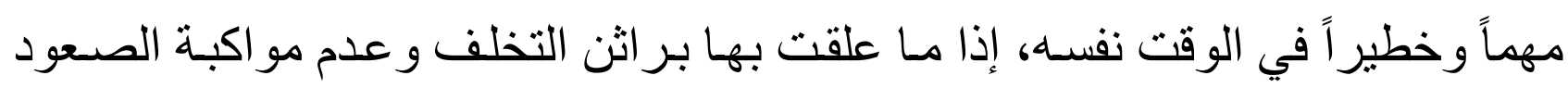

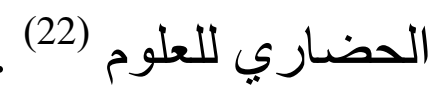

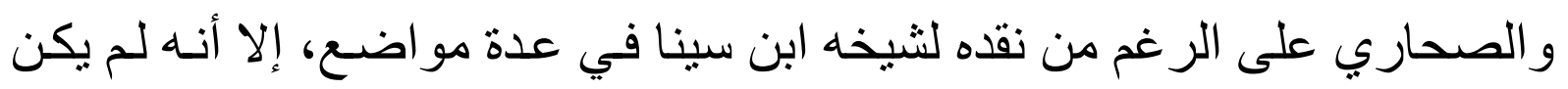

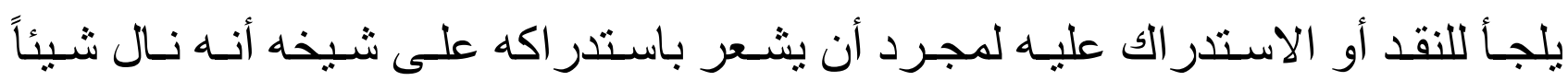

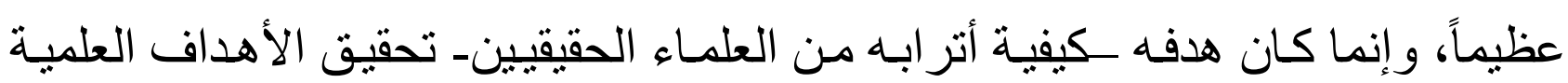
المرجوة من ور اء الععل العلمي، ولذلك نر اه يصرف النظر عن الخوض في بعض كض التهاء

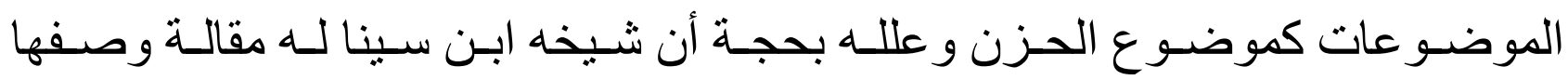
بالعظيمة في هذا الموضوع، وأن ( ما ذكره هنالك يغني عن كل إعادة، ويُعَنِّي من رام رام

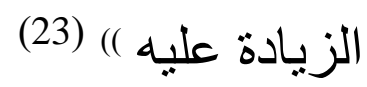

\section{أولاً : خطوات البحث التجريبي في منهج الصحاري العلمي}

لقد اختلف علماء المسلمين التجريبيين في ترتيب هذه المر احل تبعا لطبيعة كل علم تناولوه ـ ولكن هنالك عناصر للبحث التجريبي اتفق عليها الجميع ، وهي :

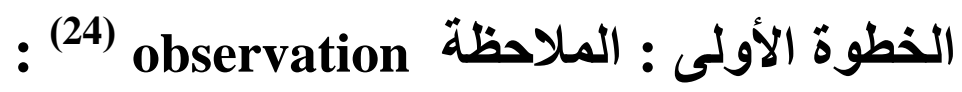

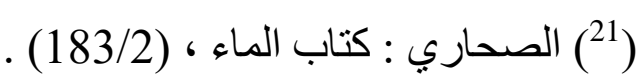

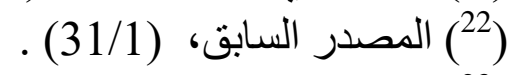

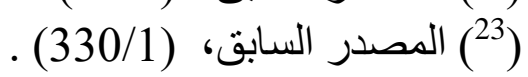
(24) الملاحظة: تطلق الملاحظة على ما يحكم فيه الحس، سواء كان ذلك الحس من الحواس الظاهرة أو الباطنة. 
و هي الرصد و التتبع للظاهرة المر اد در استها على ما هي عليه في الواقع سواء في المختبر أو في الطبيعة من خـلال الاستقراء (25) ـ ويقول ابن الهيثم : ( ... ونبتدئ في البحث باستقر اء الموجودات وتصفح أحو ال المبصـرات ، وتمبيز خو اص الجزئيات . ونلتقط باستقر اء ما يخص البصر في حال الإبصـار ومـا هو مطرد لا يتغير وظـاهر لا يثتبه من كيفية الإحساس ) (26) ـ أي أن التجارب إنما تمليها طبيعة المشكلة التي يتعلق بها البحث ، ثم تكون التجربة بعد ذلك. ولا يكتفي هذا النص بالإشارة إلى ضرورة البدء بالملاحظات الحسية الجزئية، و إنما بوضع شروط ضرورية لتسجيل الملاحظات ـ منها

الثرط الأول : وجود الوقائع الثابتة المضطردة في حدوثها .

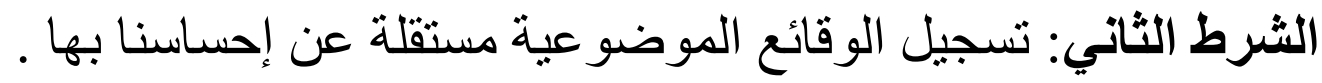
الثرط الثالث : الاهتمـام بصياغة المقدمات ، وسـلامة الاستدلال من المقدمات إلى إلى

الملاحظة العلمية هنـا أنها رؤيسة وفحص ظـاهرة موضـوع الدر اسـة مـع الاستعانة

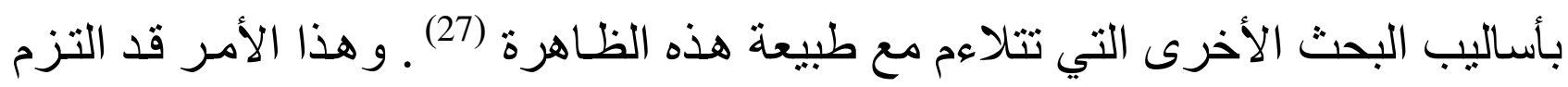

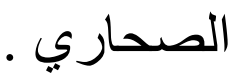
وظائف الملاحظة عند الصحاري، وهي : 1) الملاحظة من أجل التشخيص . و هي الغالبة والأكثر استخداماً لدى الصـحاري، و هي تمثنل نموذج الملاحظة العلمية في منهجه التجريبي، و الكتاب مليء بالنصوص الدالة على ذللك. ونر اه في موضع من كتابه يقعد لهذا الأمـر ، و عليـه تقوم در اسـة المـرض و علاجـه، ويسـي

و هي إحدى صور المعرفة التجريبية تقوم على التوجه إلى الثنيء في يقظة وانتباه. و الملاحظة مقابلة

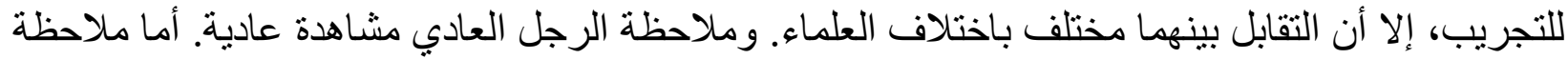

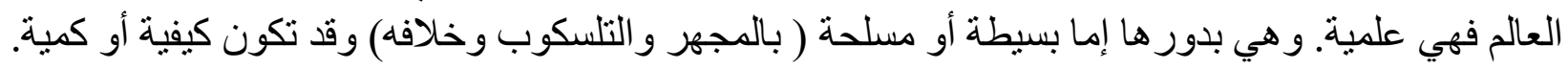

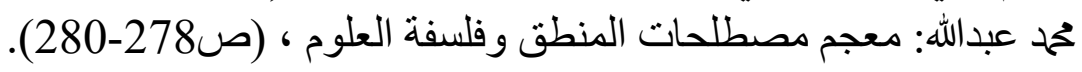

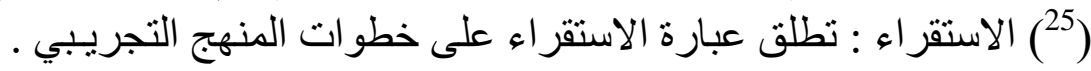

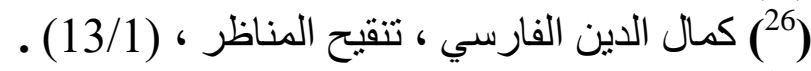

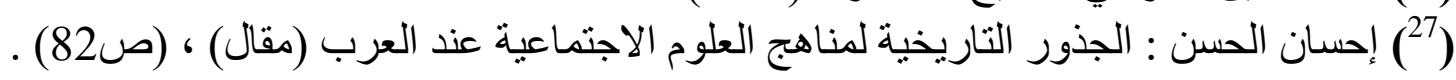


الملاحظة بـ( التتبع)، ويقول في هذا الصدد : (( التتبع في الطب: أن نتبع علامات

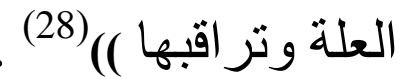

وفي بعض الأحيان يقرن الصحاري بين المشاهدة و اللمس في حسم بعض القضـايا الطبية الخاصة بحياة الإنسان، ويؤكد على الجانب الإكلينيكي للنبض قائلاً : (ر فالنبض النان علامة الحياة، وتوقفه علامة الموت إذا صـاحبته برودة و اصفر ار واستمر يوماً كاملاً ()) (29) وهو يريد أن يصل بذلك إلى نتيجة مؤداها : (( ... لا يصح دفن صـاحب السكتة) إلا بعد انقضاء يوم من سكتة نبضه ()) (30)

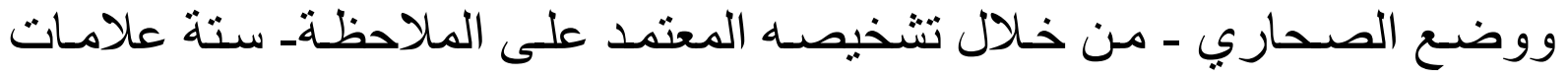
فرّق بها بين الحصبة والجدري من حيث المنشأ، وحجم البثور، وبروز هـا على الجلد،

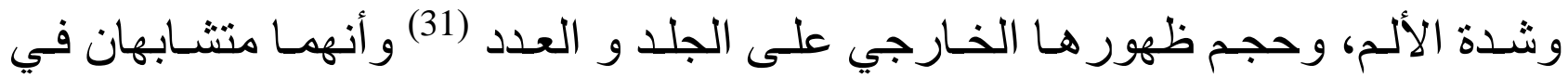
علامات الثفاء : ((و علامات السالم منها ( الحصبة ) كعلامـة السليم منهـ ( الجدري )

و على مر اقبة العلامـات كان الصحاري يحدد علاجـاً للأمر اض قبل ظهور هذه

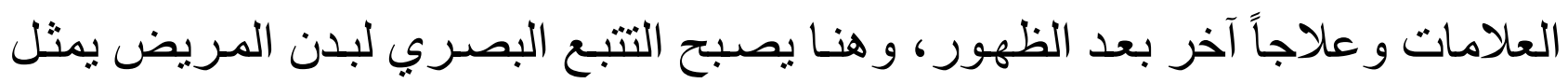

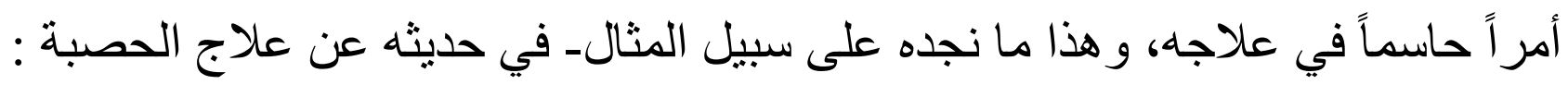

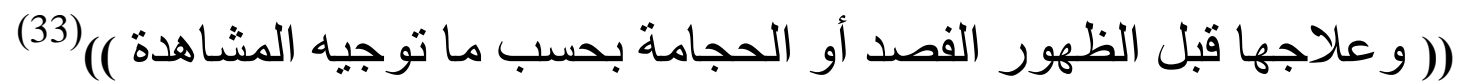
وتكرر اعتماده على المشاهدة الإكلينيكية في تتخيص الأمر اض ومتابعتها سريرياً في حديثه عن مرض الجذام وعلامات ابتدائه مع شيء من التأمل (34) ـ وكذلك في تفقده

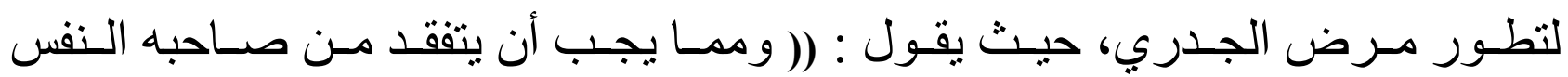

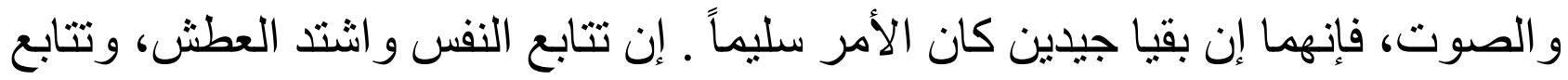
الكرب، وبرد الظاهر ، و اخضر لون الجدري فقد قرب الهلانك )(35)

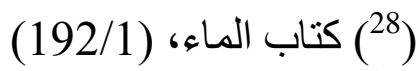

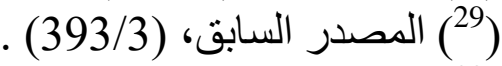

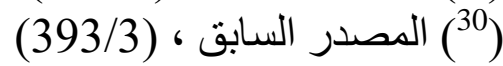

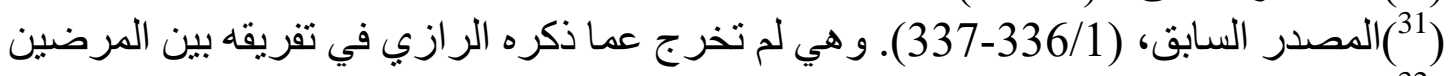

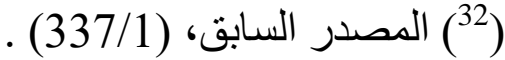

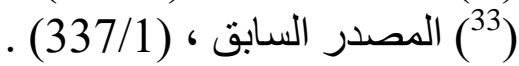

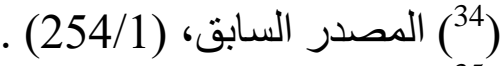
(249/1) (25) (المصدر السابق، 


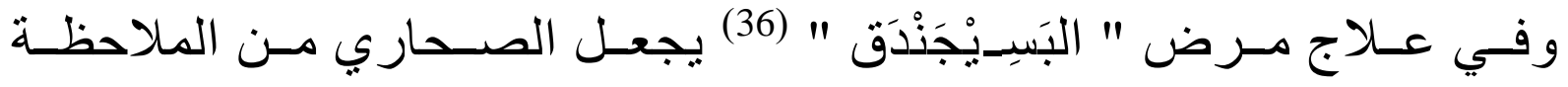

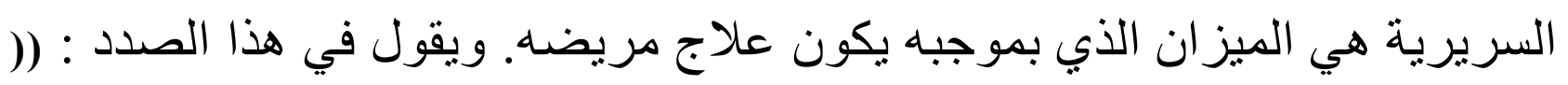

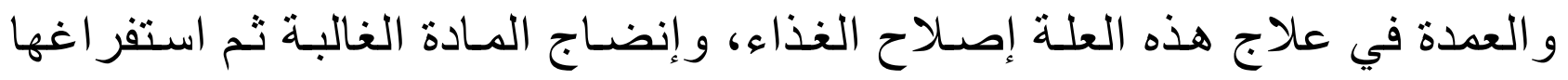

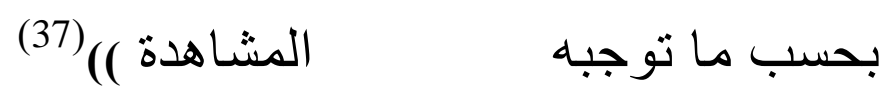

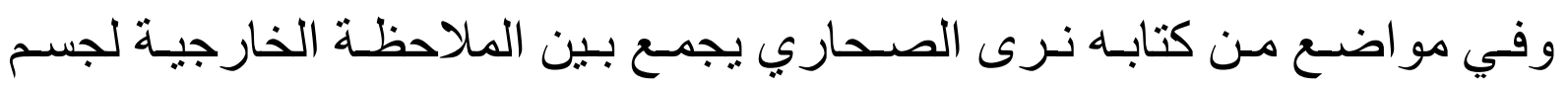

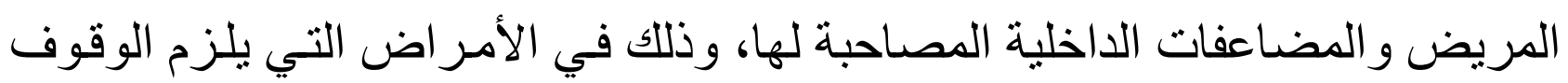

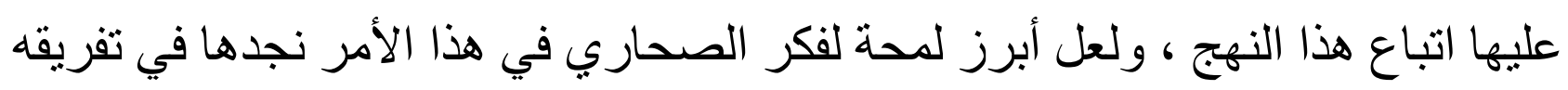

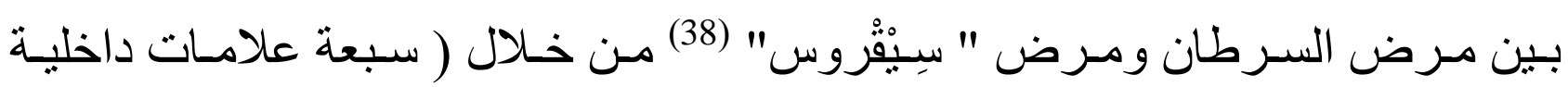
وخارجية) تتو افر في المريض الترطن (39).

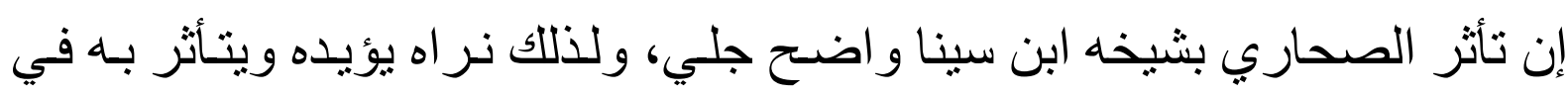

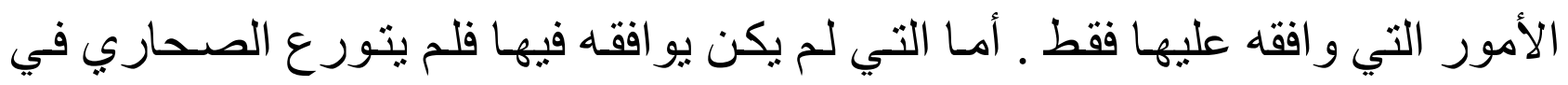

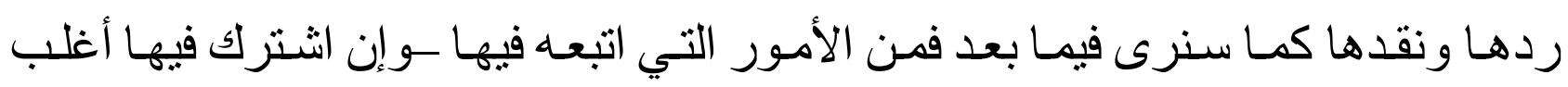

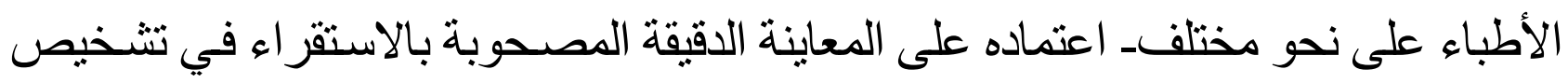

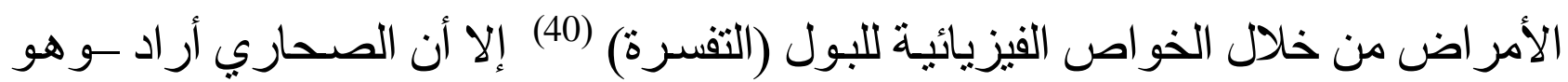

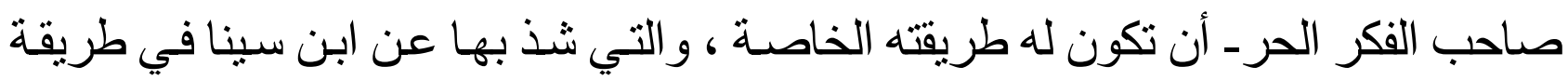

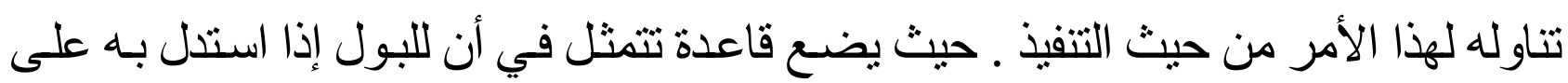

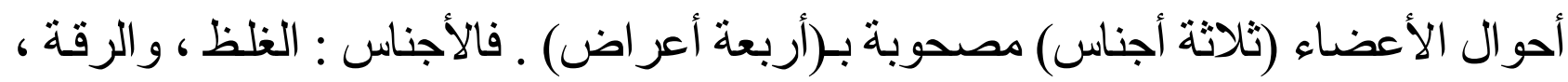

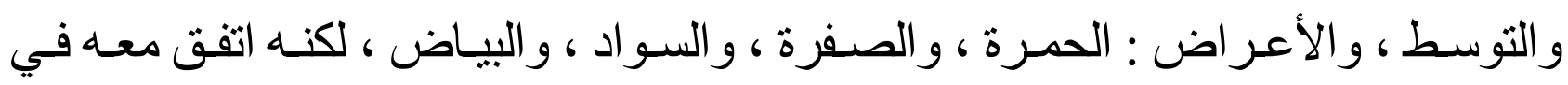
الثروط الواجب توفرها في عينة البول المر اد فحصها (41).

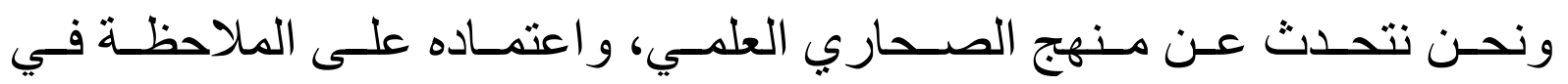

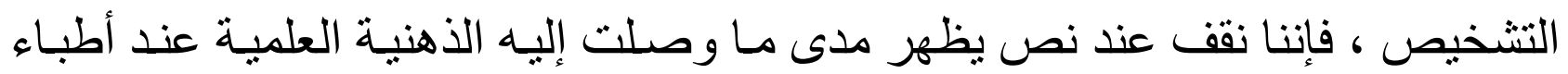

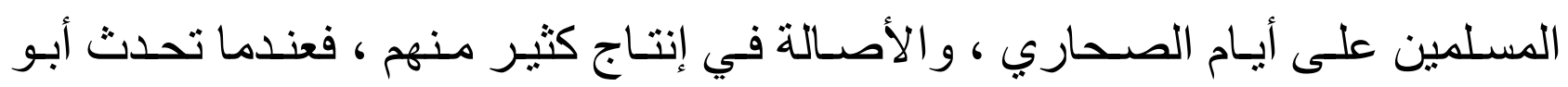

(37) (البسيجندق : علة تتلوى معها جميع الأعضاء . . ابن هبة الله : المغني في الطب ، ص 176 ،

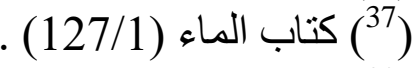

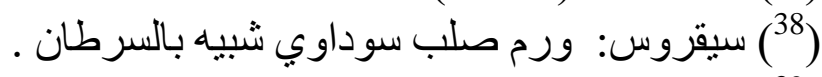

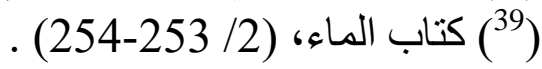

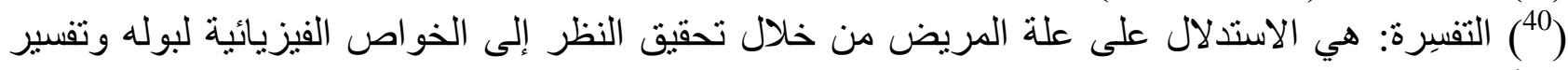

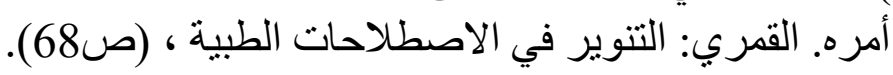

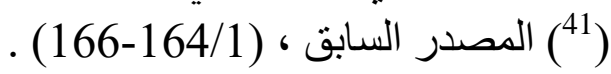


عبدالله الصحاري عن نوع من الخيوط الطبيـة ويسمى بـ(البَرِيم) ، و وعن استخداماته

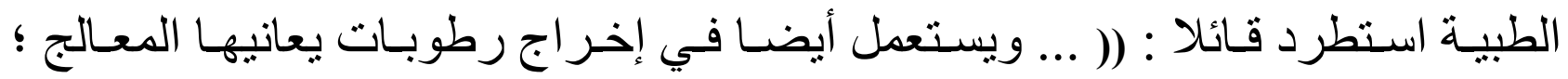

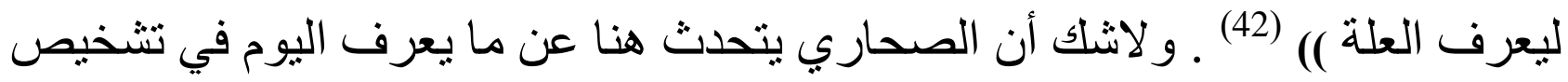

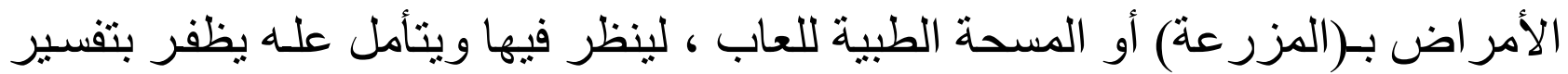
للمرض ـ فلم يكن ينقص الصحاري لكي يتوصل إلى نتائج باهرة سوى (المجهر) .

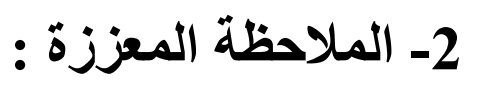

ويقصد بها: تلك المشاهدات العامة التي كان يستعين بها الصحار الصاري لإثبات أمور

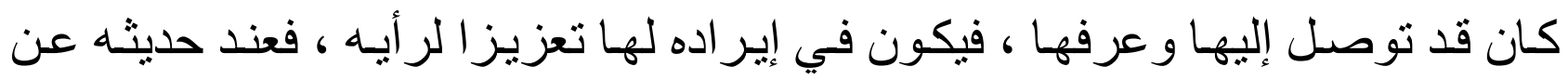

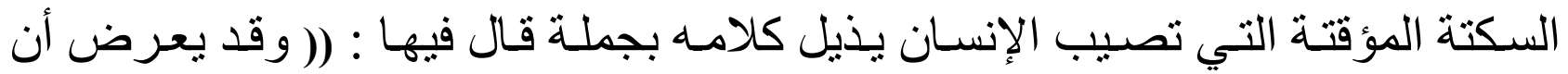

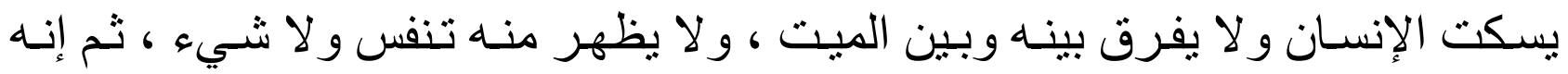

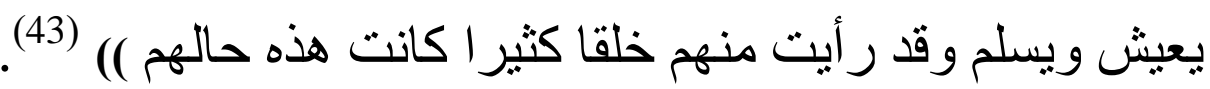

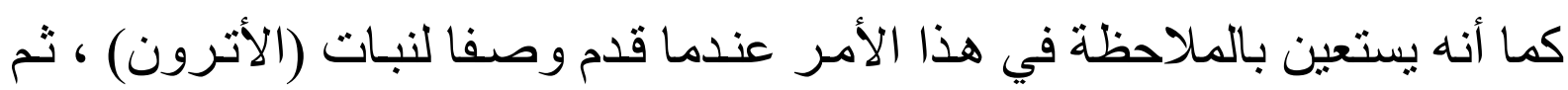
يتبع ذلك بقوله : (( ور أينا في بعض البلدان أن الرعاة يقدمونه للماثية و الأنعام للتسمين واستدر ار اللبن ()) (44).

\section{3- الملاحظة المقرونة بالتجربة :}

ويقصد بها : الملاحظة التي تكون جزءا من المنهج التجريـبي الذي يستخدمه الصحاري في تناوله لبعض القضايا الطبية ، و هي الأكثر استعانة من قبل الصحاري

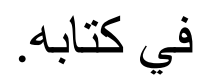

و على الرغم من أننا سوف نعرض لها عند الحديث عن التجربة عند الصحاري ، إلا أن ذللك لا يمنع من إير اد نماذج منها ، استكمالا لموضوع الملاحظة عند الصحاري

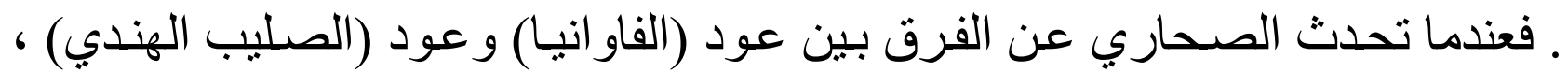

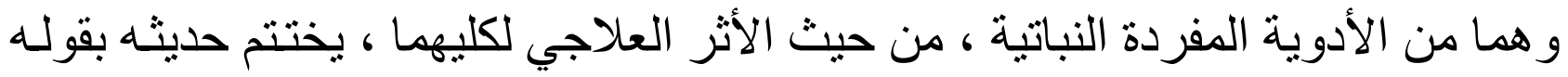

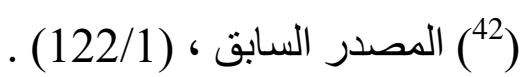

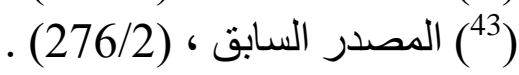

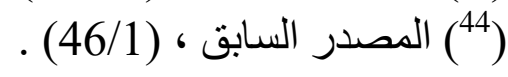


: (رأما الذي وققنا عليه من أمر عود الصليب الهندي ، عيانا وتجربـة ، فليس فيه ذلك

وفـي موضـع حديثـهـ عـن مسـبيات السَّكتة (46)، يقـول : (( و اعلـم أن المشــاهدة

و المعاينة وطول التجربة تؤيد أن السكتة قد تعرض عن فزَع أو بلغم أو دم غليظ )) (47)

ويرى الصحاري أن فض النزاع بين الأطباء حول أول عضو يتكون في جسم الإنسان قبل غيره : القلب ، أم الدماغ ، أم العينان ، أو الكبد ، بأن السبل إلى معرفة ذلك الك الك

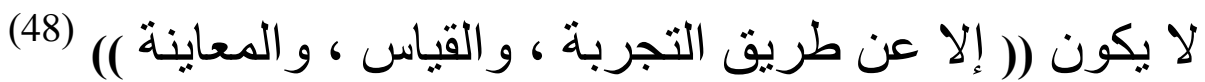

و) : قأخير ا يحدثنا الصحاري عن مرض جلدي يعرف بـ(العرق المديني) قائلا

و أكثر ما يعرف في الساقين وقد رأيته على اليدين وقطعه مؤلم )) (49).

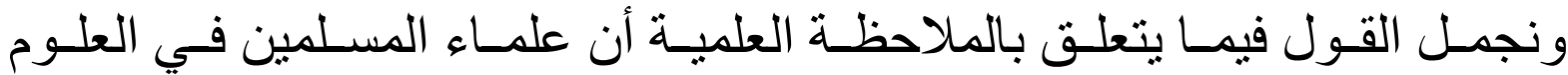

التجريبية كانو ا يتمتعون باطمئنان كامل إلا أن الخبرة الحسية بكل أنو اعها تعد مصدراً

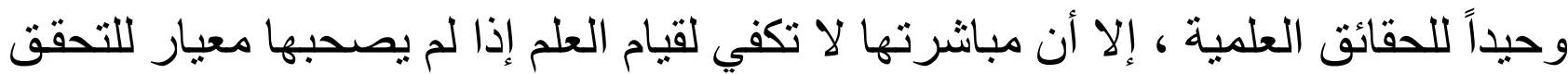
من صدق فروض قد وضـو ها من خـلال استقر اء مـا شـاهدوه للوصول إلى الحقائق العلمية فكانت التجربة هي المعيار.

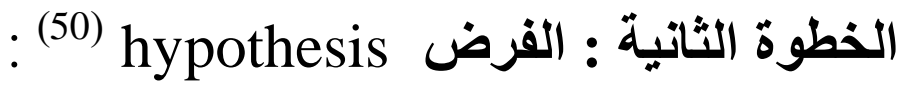

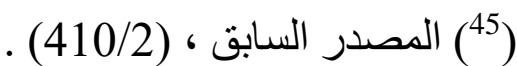

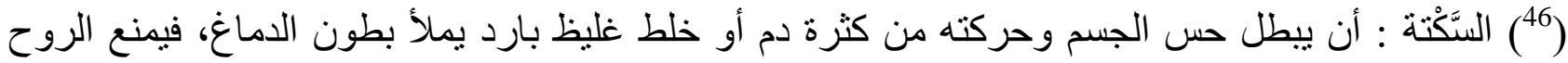

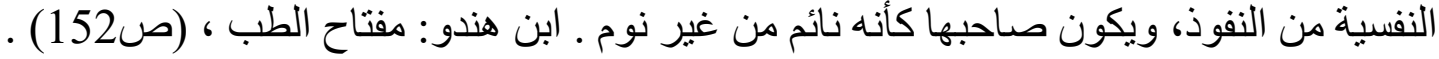

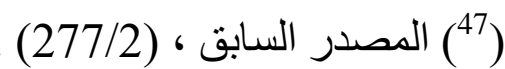

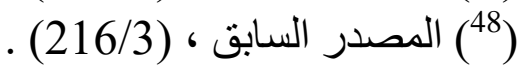

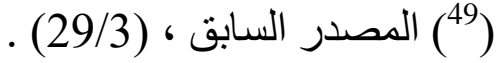

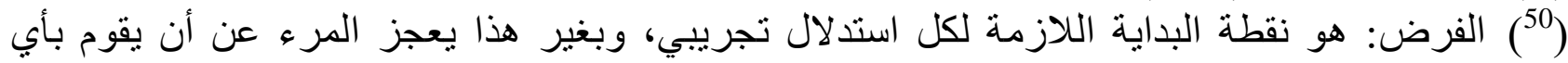

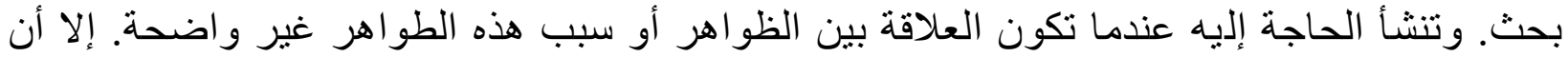

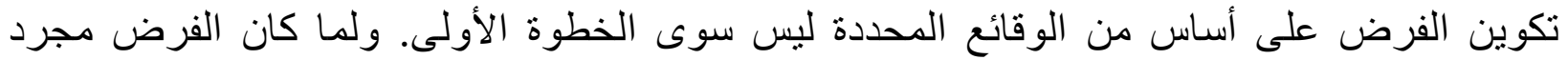

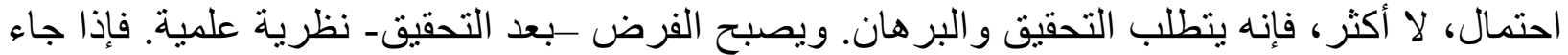

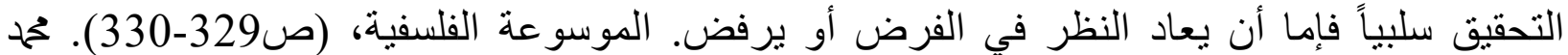
عبدالله: معجم مصطلحات المنطق، (صان بل167-169). 
وفي هذه الخطوة يتجـاوز الباحث الوصف البسـيط للظـاهرة أو الظـواهر إلى في

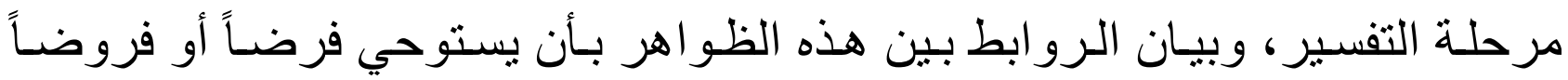
يفسر بها تلك الظو اهر. فالفرض هو: تفسير مؤقت للظـاهرة موضـوع البحث حتى تتحقق من صـحته

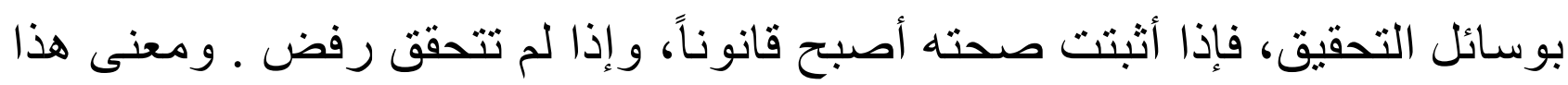
التفسير أن يتفق و اقعه مع قانون (51) ، ولذلك فإن الفرض بعد أخصب أجز اء المنهج التجريـبي وفي التحقق مـن صـحة الفروض مـن عدمها ، فقد اسـتعان العلمـاء التجريـبيين بقاعدة مهمة في هذا المضمار ، هما قاعدة " السَّبَر و التقسيم ".

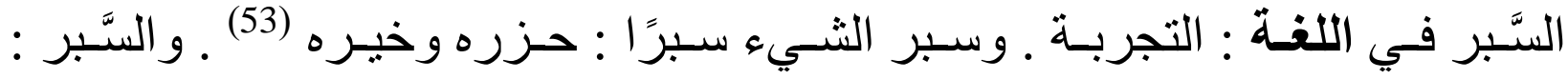
استخر اج كُنهِ الأمر ـ وسَبْر الجرح : قياسه بالمسبار لمعرفة عوره (54) وفـي الاصـطلاح: حصـر الأوصـاف التـي توجـد فـي الأصـل و التـي تصــلح للتعليل(55)،و اختبار كل و احد منها (56) ، ونرديد العلة بينها في كونها صالحة للعلية أم لا ، ثم إبطال ما لا يصلح فيتعين الباقي للعلية (57) فعمل العـالم المجتهد وفق هذه القاعدة ، جمـع الفروض (الأوصـاف) التي يظن أنها تصلح لأن تكون علة ، ثم يتحقق ويختبر كل واحد منها بوسـائل التحقيق ، فيستبعد الفروض ها (الأوصاف) التي لا تصلح أن تكون علة ، فلا ييقى إلا ما يصلح أن يكون علة ، وهو المنهج الذي سـماه فرنسيس بيكون بــ(منهج الحذف و الاسـتبعاد) بنـاء على مـا وصـله مـن تراث

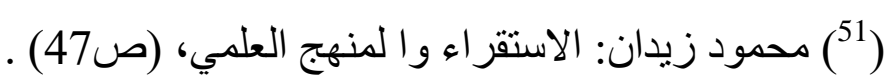

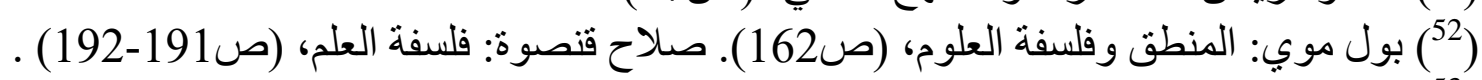

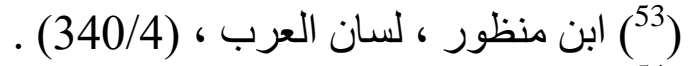

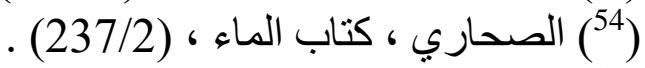

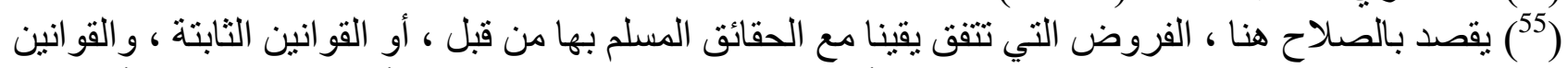

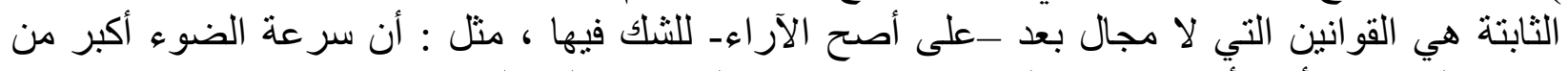

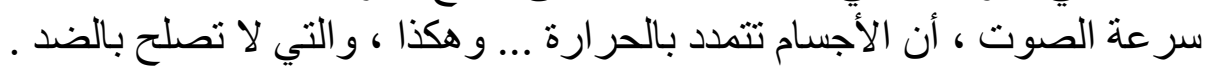

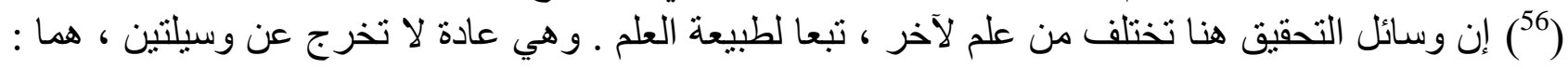

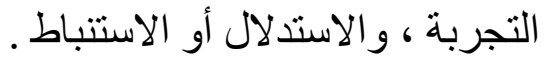

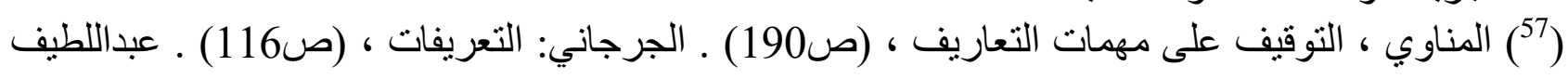

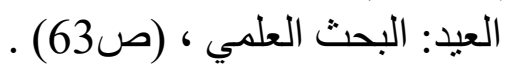


المسلمين فيما يتعلق بمنهجم العلمي ، و هي ما يسمى في منهج الاستقر اء الحديث بــ(المنهج

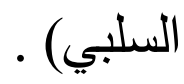

\section{الخطوة الثالثة: التجربة}

ويظل أبو محمد عبدالله الأزدي الصحاري ( ت456هـ/ 1064م) أحد ألهع علمـاء

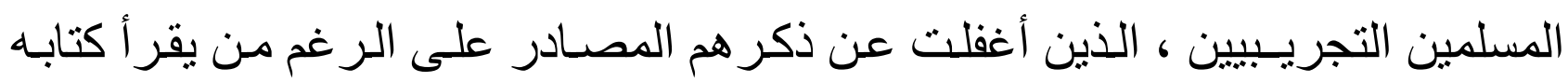

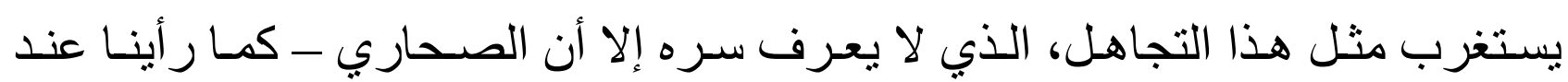
الحديث عن الملاحظة في منهجه العلمي- يصنف في زمرة جابر و الر ازي وابن الهيثم

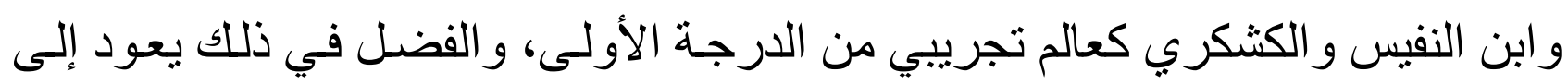

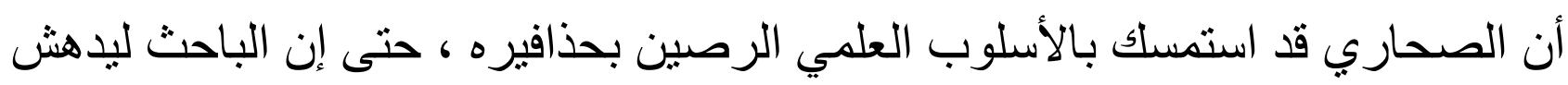

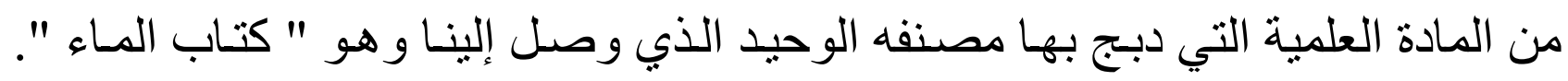

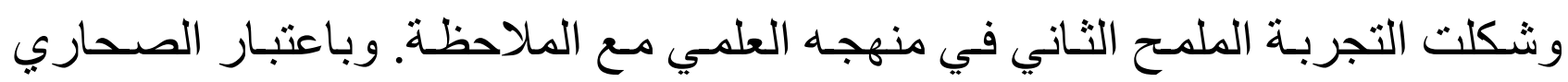

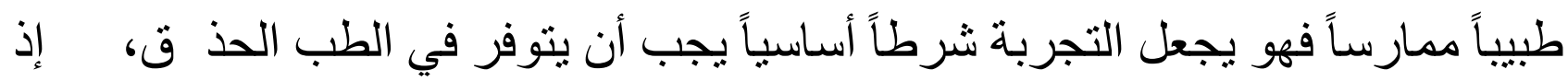

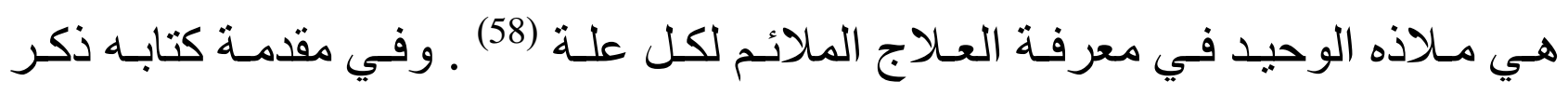
مصادره التي بناه عليها، وكانت التجربة أولها : (وقد عوّلت في هذا الكتاب على مـا لكال

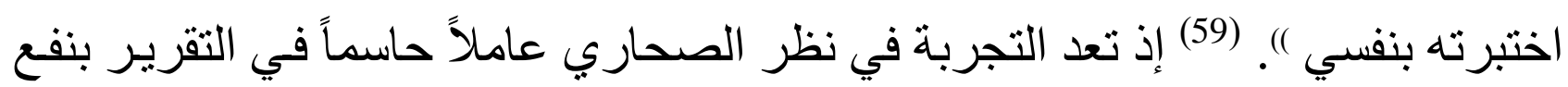

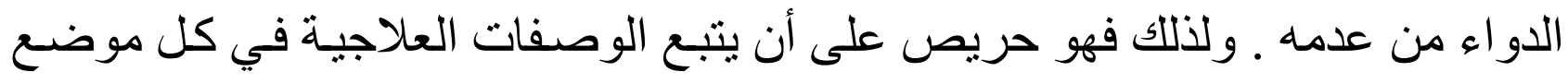

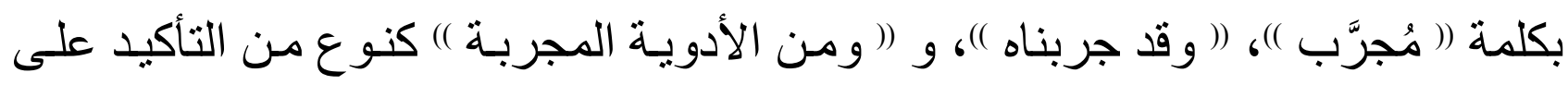
أنها مرت بمر احل الاستقر اء العلمي حتى ثبتت صحتها. فعلى سبيل المثال عند حديثه

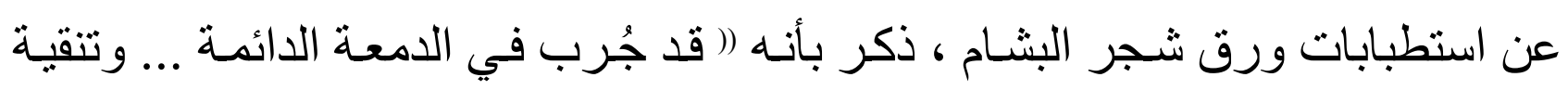

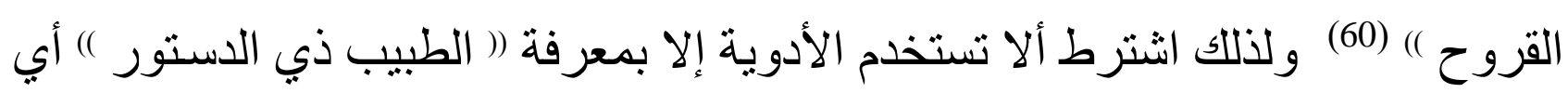

المتمكن من صنعة الطب، و المتخرج على أساتذتها الكبار (61)

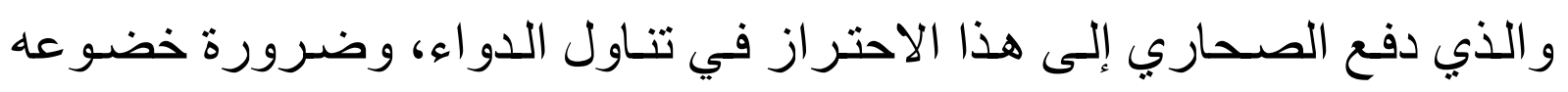
لنظر الطبيب الحذق ، أن تناول الناس للأدوية كيفما اتفق يؤدي إلى فقدان الدواء لفاء لفعاليته

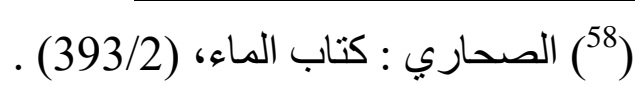

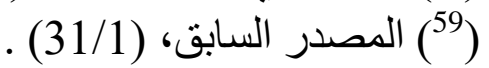

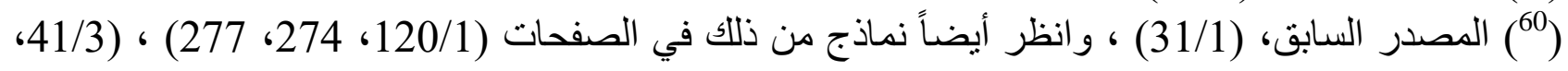

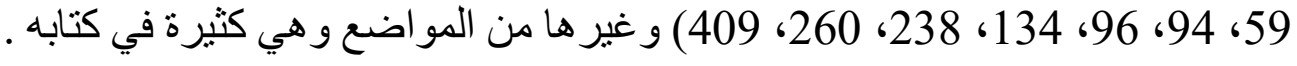

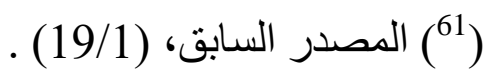


العلاجية إذا ما استمر المريض في التركيز على نوع معين منهـه ، وهو ماقصده عندما

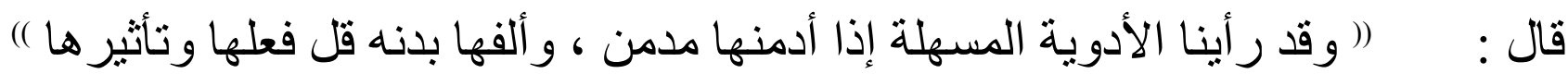
(62) ، وهو أمر يعود - من وجهة نظر الصحاري- إلى سلوك اجتماعي يختلف من بيئة

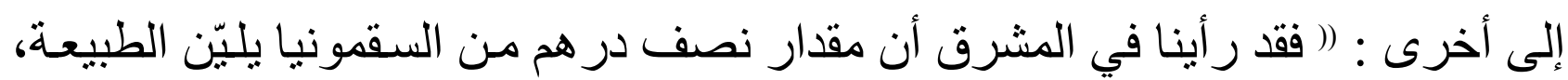

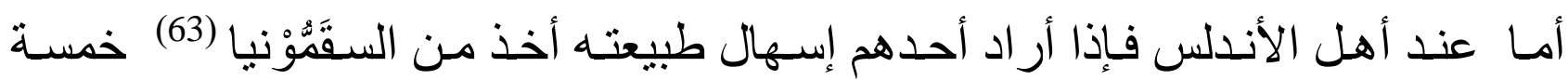
در اهم ، وقد لا يفعل هذا المقدار عند من تعود على ذلإد اللك الدواء )) (64) ويظل الحكم على الأشياء عند الصحاري مرهون بما تسفر عنه التجربة، و لا سبيل غيره ولهذا لا يعتد بما يصدر عن الأسلاف مهما بلغت مكانتهم العلمية، و هو ينطلق من مبدأ علمي قائم على تمحيص وتدقيق كل ما يصل إليه - فهو - على سبيل المثالـ عندما تحدث عن ( الرَّاوندالصيني) ، ذكر رأي شيخه ابن سينا بأن عده من جملة الأدويـة

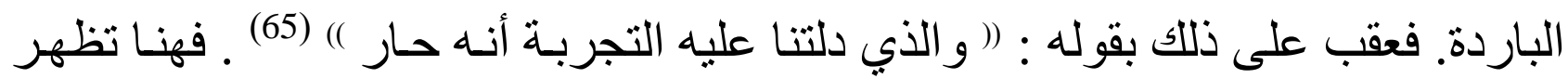

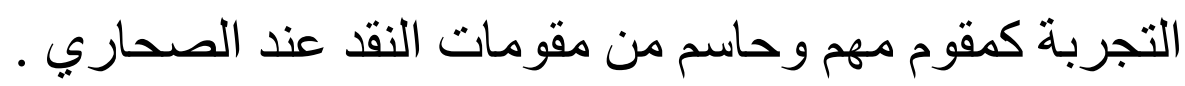

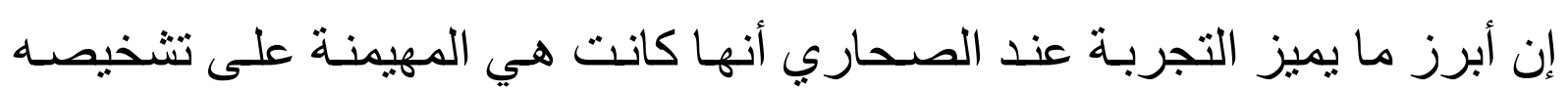

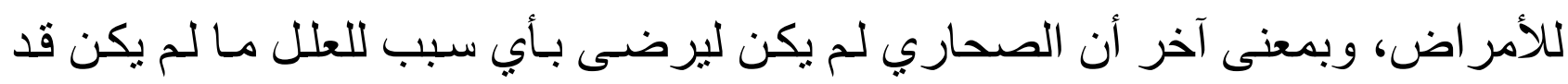

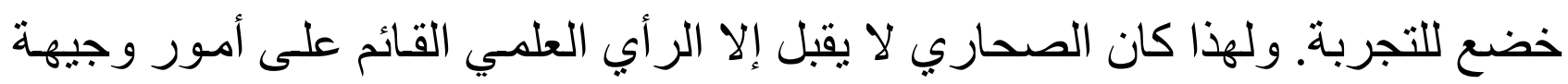

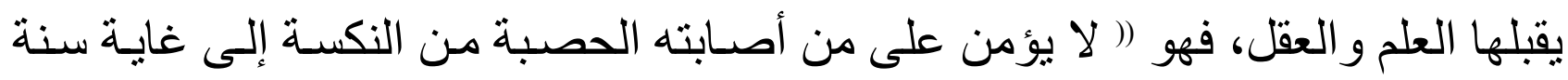

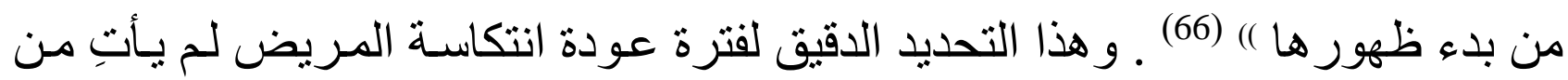

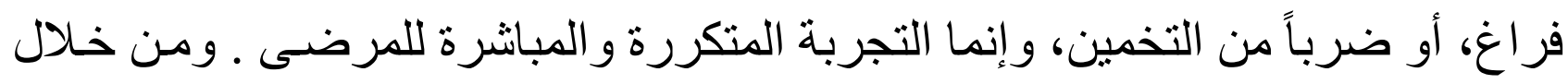

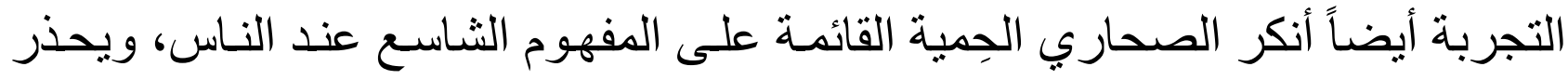

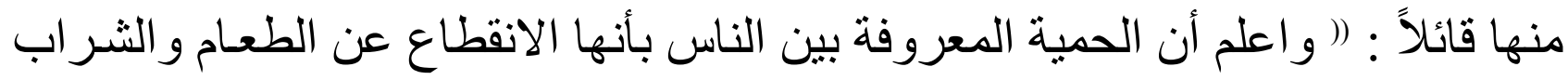

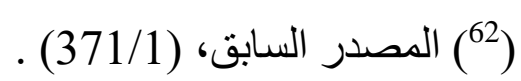
(63) السقمُونيا : لبن شجرة صغيرة تعلو على الأرض قدر المتر. و وهي لفضة يونانية تعني المحمودة. ابن الجزار

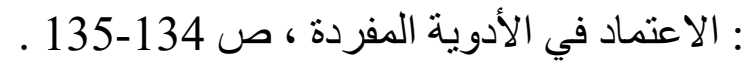


ليس من صنعة الطب في شيء. فليست الحمية في تجنب الأغذية ولو كانت رديئة ) (67)

ويحرص الصـحاري على أن لا يذكر أي رأي علمي، وإن لـم يتعلق بالطب، إلا

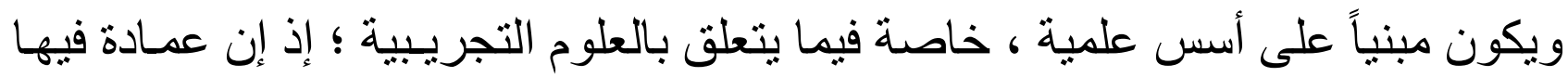
على التجربة و لا غير، فنر اه يستعين بالتجربـة الثخصية عند حديثه عن ميـاه الأنهار و الآبار و أنو اعها، و الخو اصله الفيزيائية المميزة لكل نوع منها (68) و إذا كان الدو اء متعلق بعلاج العلـة فلابد أن يكون بمقدار معين يتناسب مـع حـال المريض، ويكون تحت إثر اف الطبيب ـ أي أن الدواء ـ و وإن كان في الإصـل علاجـاً. إلا أنه يمكن أن يكون خطيراً على صحة المريض إذا ما أُخذ على غير وجها الصحيح، و هـذا الحـد في تـأثثر الـدو اء لا يمكن الوصـول إلى تحديـده إلا مـن خـلال التجربـة المتكررة، حتى يستطيع الطبيب أن يحدد ما هي الجرعة المناسبة بالضبط ـ وهو ما دفع

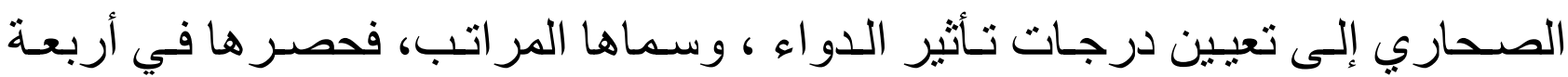
مر اتب، هي (69) : الارجة الأولى : إذا لم يكن تأثثر الدواء في بدن الإنسان محسوساً إحساساً ظاهرياً.

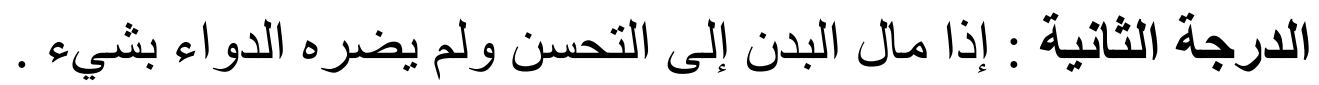

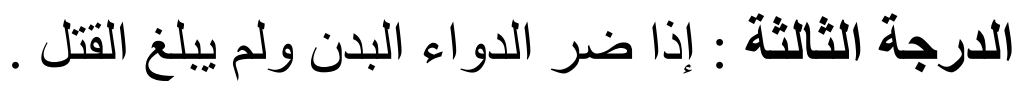

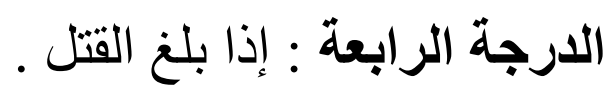
ويجعل الصحاري مدار هذه المراتب منـاط التجربـة ، حيث يقول بعد ذكر لهذه المر اتب أو الدرجات : (و وكل ذللك فهو في المقدار المخصوص من الدواء، فإن تمـادى المريض في الاستعمال على غيرهو هن الطبيب؛ أضر الدواء ضرراً بليخاً )، (70)

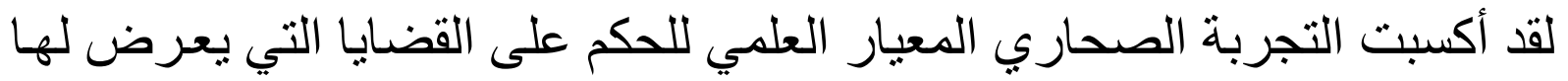
في كتابه ، وكأنه قد اطمأن إلى ذلك، وهو كذلك فعلاً لدرجة أن الأمور لديه ـ في بعض لهض الأحيان- تكون محسومة إذا ما كانت تتعلق بشيء قد تأكد منه فعلاً، فعلى سبيل المثنال :

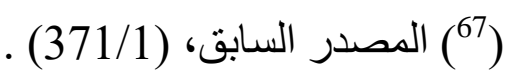

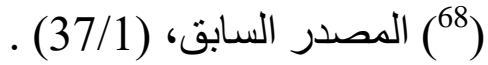

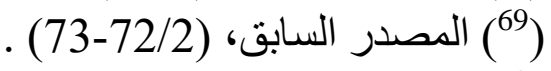
(73/2) (73/2) المصدر السابق، (73/79 (ل) 
عندما أخذ الصحاري بشرح كلمة " النَّيثث " وذكر أنه ضرب من سمك البحر نقلاً عن الأن

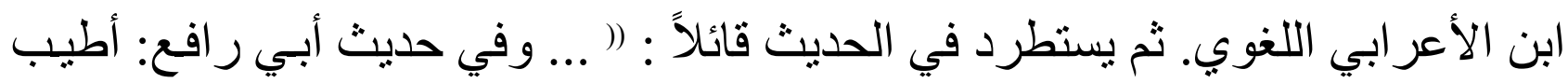

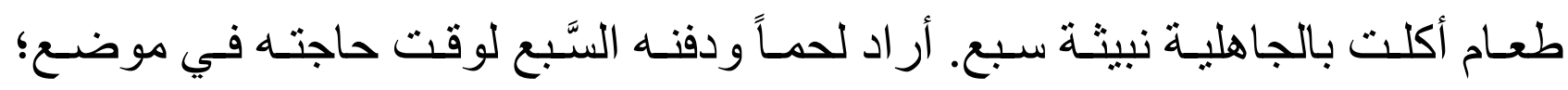

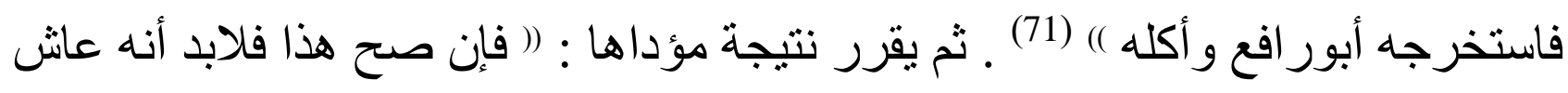

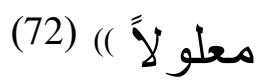

فالصحاري حكم هنا وفق ما أملاه عليه مخزونه العلمي، و هذا الحكم يتعلق بقضية

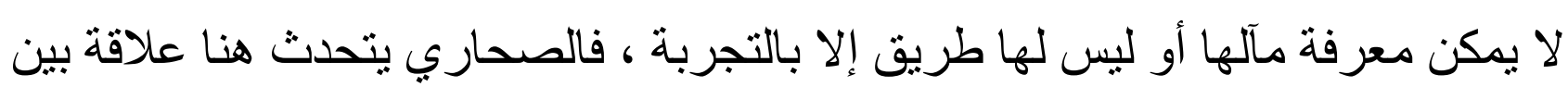

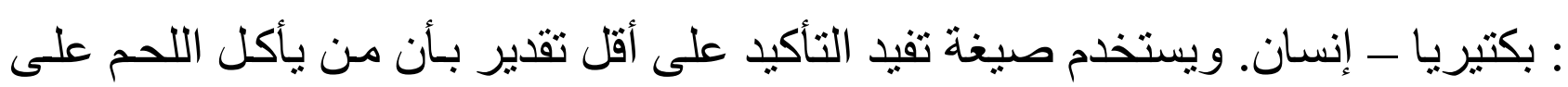

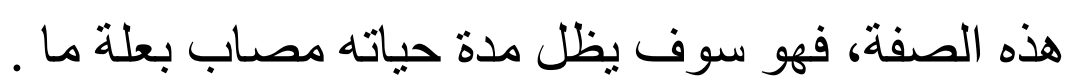

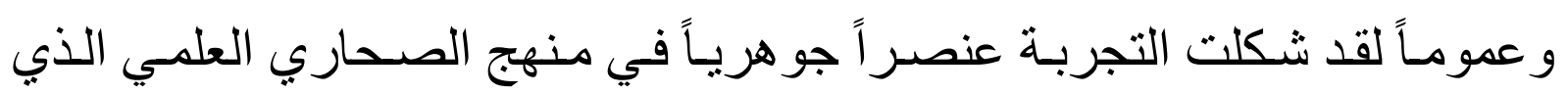

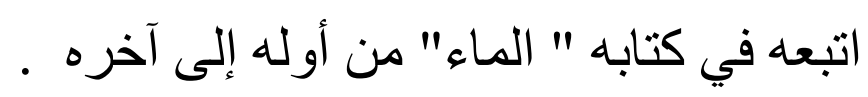

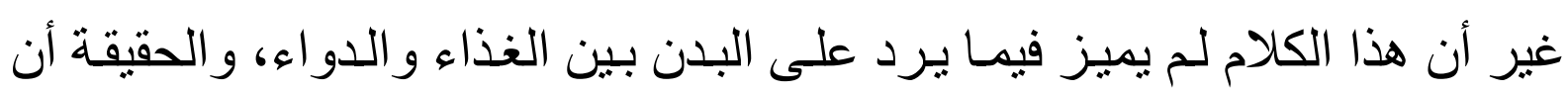

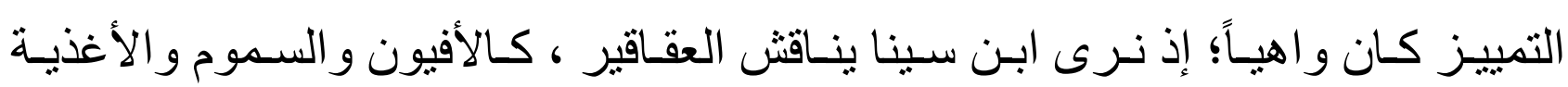

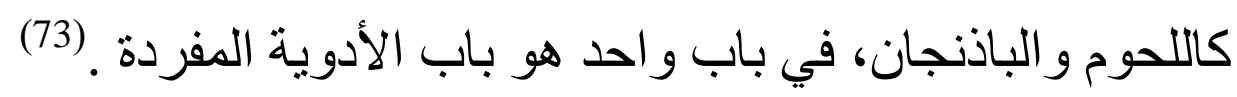

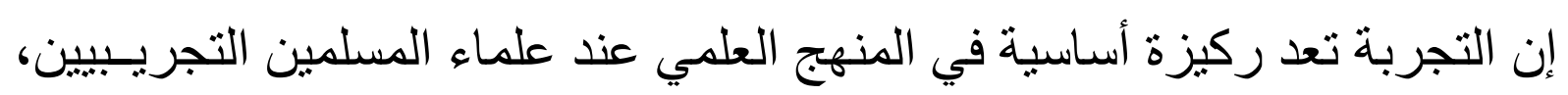

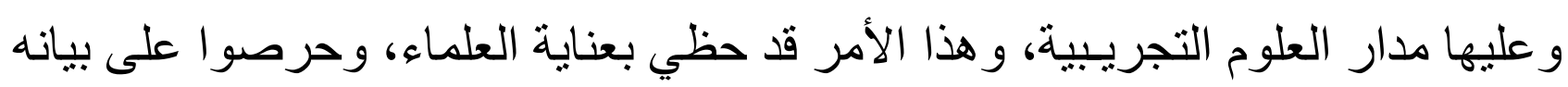

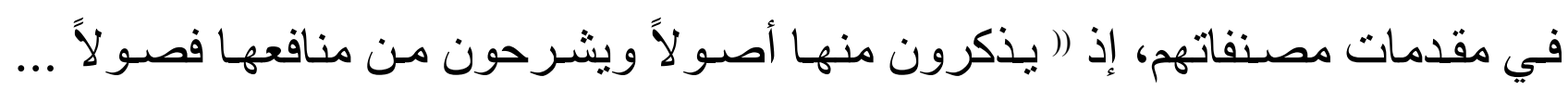

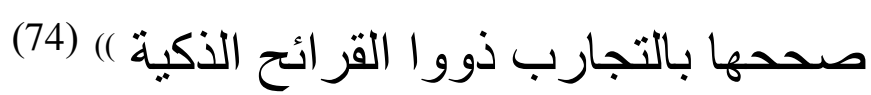

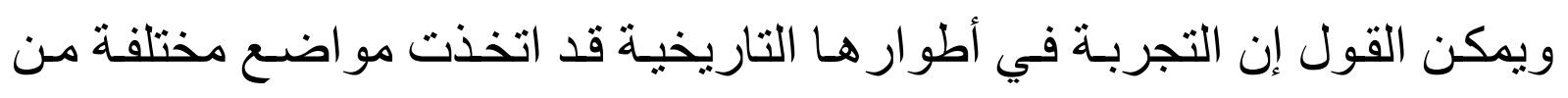

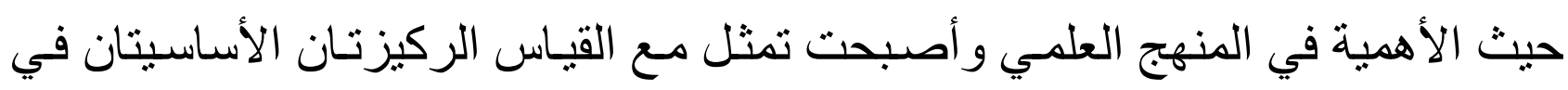

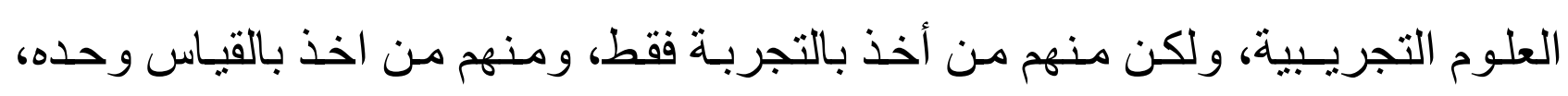

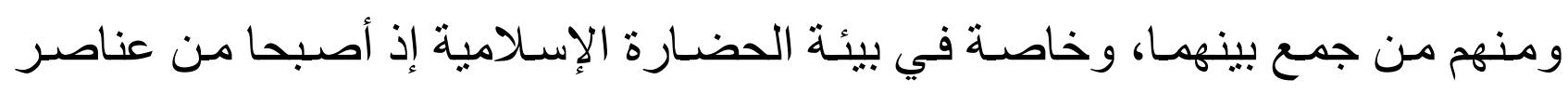

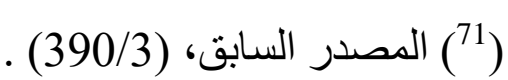
(32) (32) (الدصدر السابق، (390/3) . (390/3). (73) بول غليونجي: الأسس النظرية للطب الإسلامي ( مقال )، (ص214) (214) .

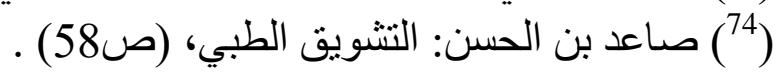


المنهج العلمي في العلوم التجريبية ، بل وأصبحت التجربة مدار البحث في هذه العلوم

إن مرحلة التجربة هي المرحلة التي يحاول العلماء فيها استخلاص المبادئ العامـة

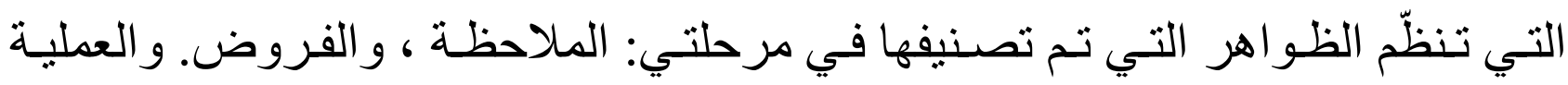

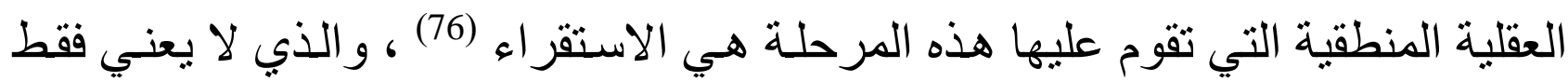

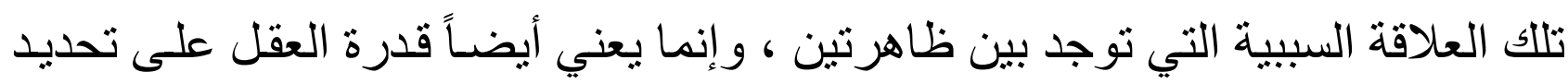

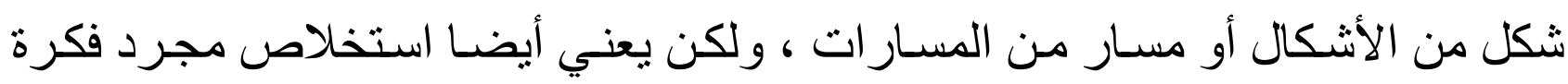
تمكننا من فهم الإدر اكات المتفرقة وغير الدقيقة التي حصلناها عن الأشياء، وكان العقل

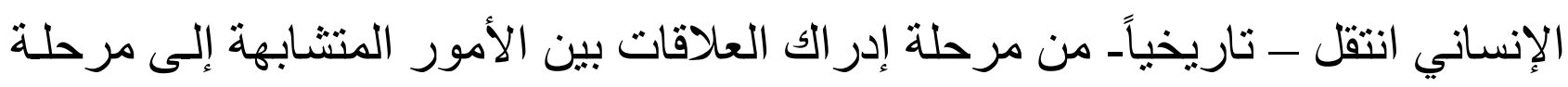

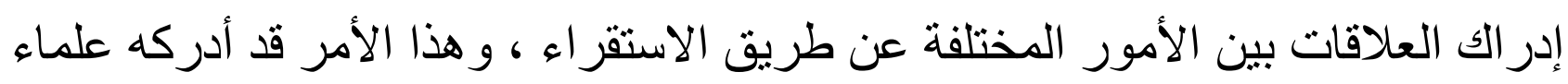

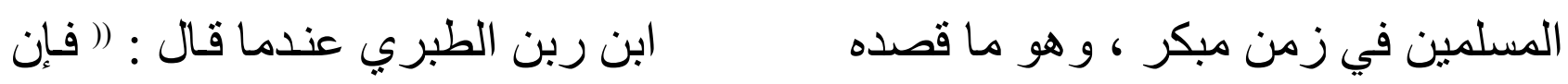

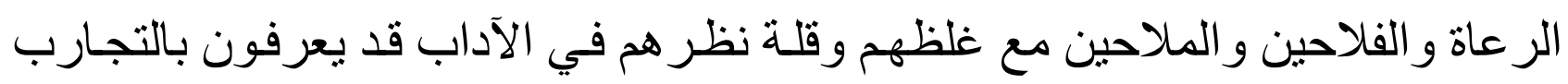

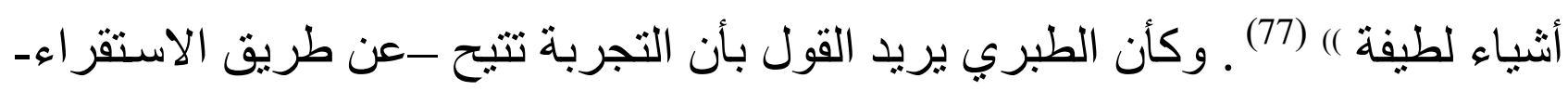

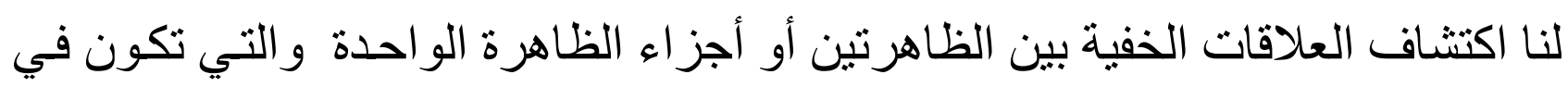

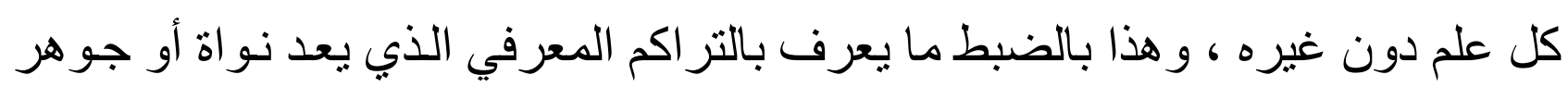
تطور الفكر العلمي في تاريخ العلوم .

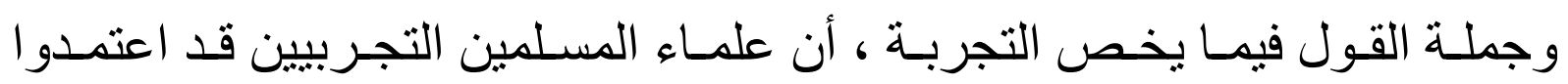

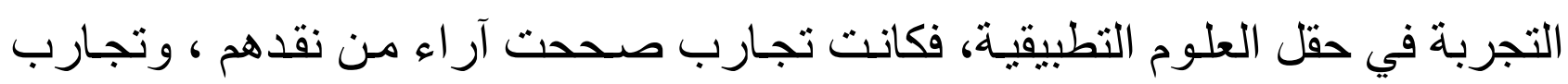

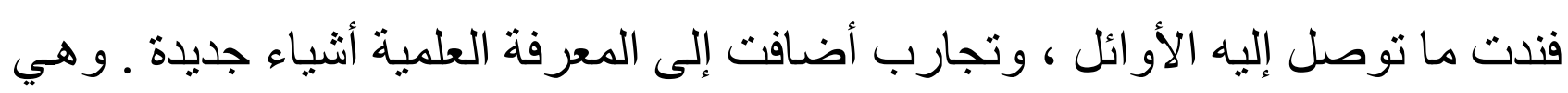

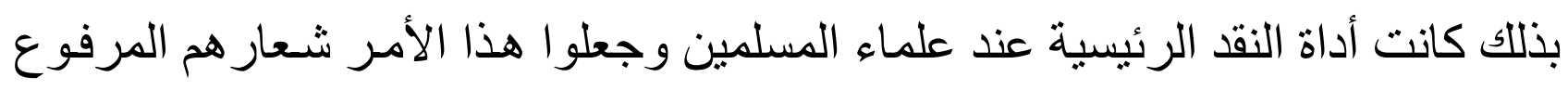
وفي مقدمات مصنفاتهم. ولم تكن التجارب بسيطة أو ساذجة بل كانت في بعض التماء الأحيان

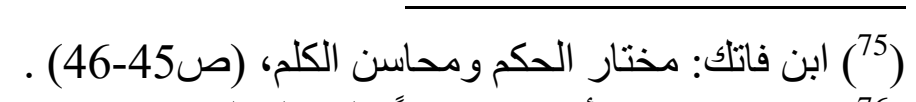

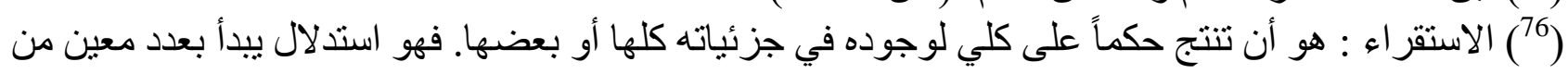

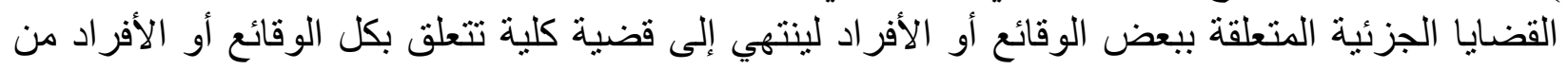

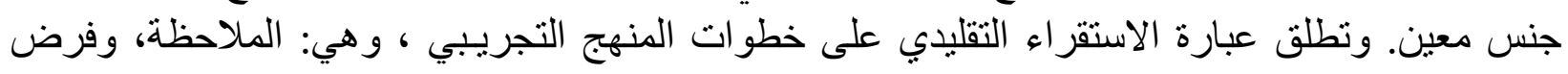

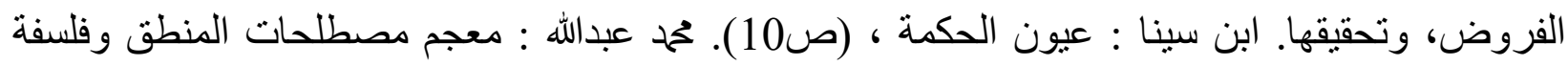

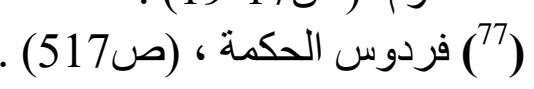


معقدة جدا ، و لا نريد أن نبالغ بأن معظم الأجهزة العلميـة التي استخدمت في التجارب

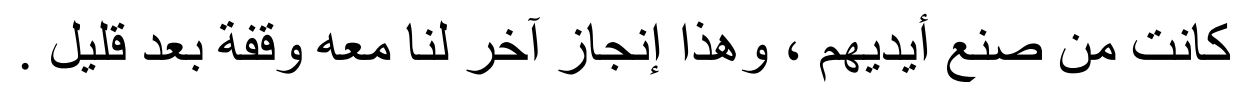

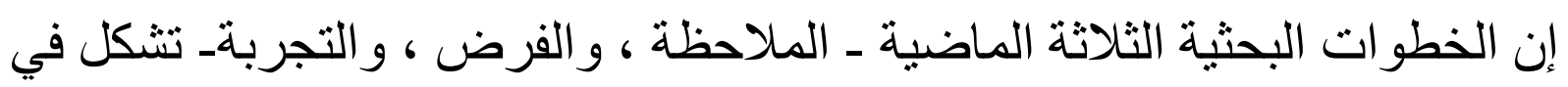

مجمو عها مرحلـة أولى في البحث التجريـبي عند المسلمين ، و التي مـا يطلق عليها

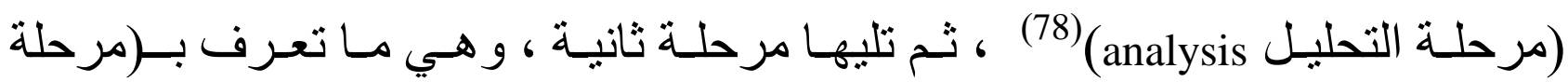

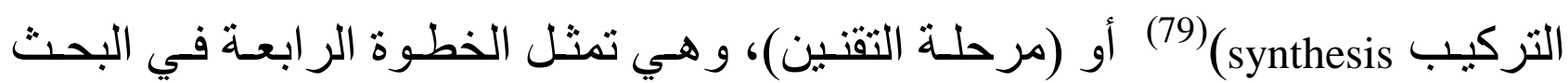

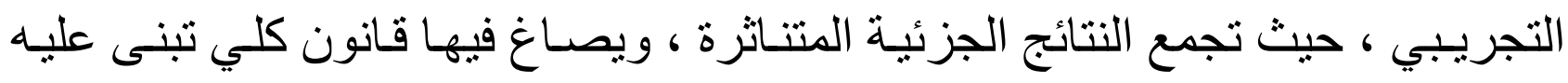

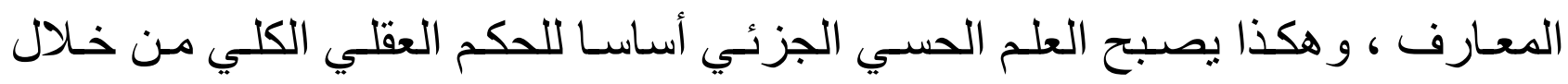

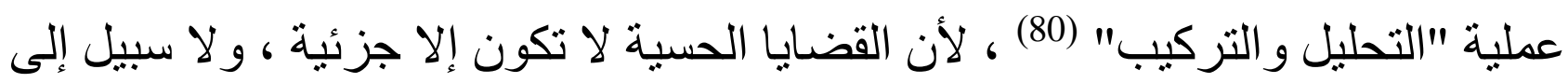

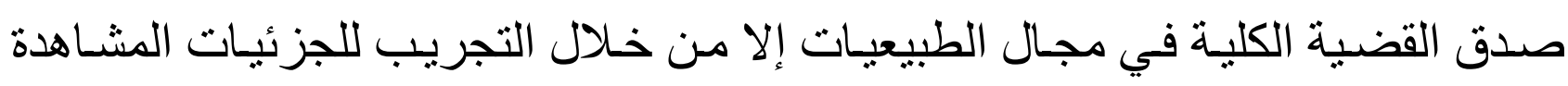

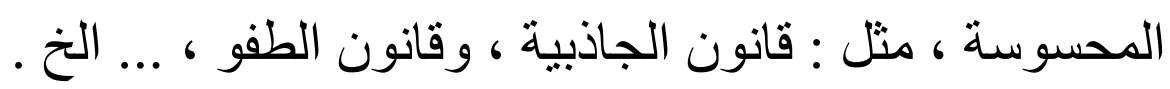

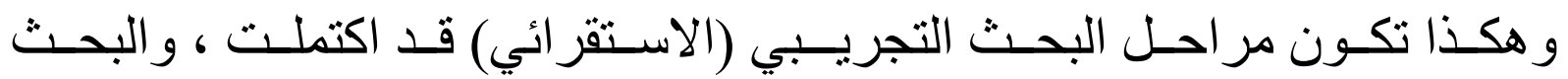
التجريبي نفسه يعد أحد ملامح المنهج العلمي في العلوم التجريبية عند المسلمين .

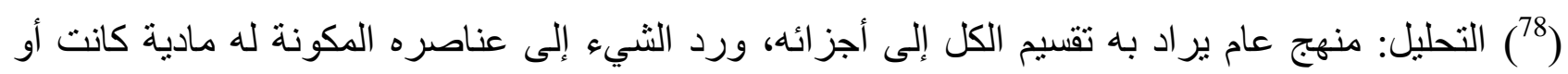

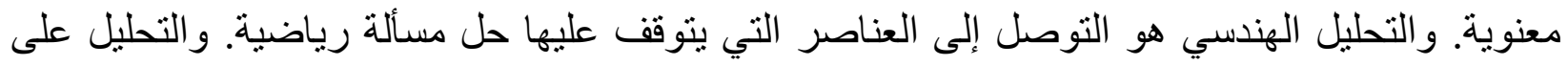

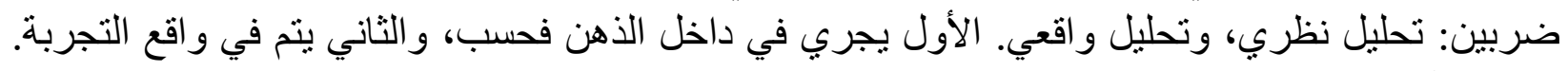

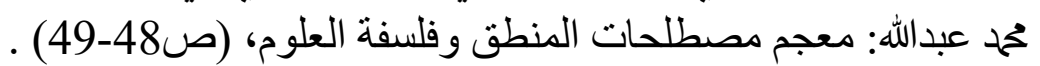

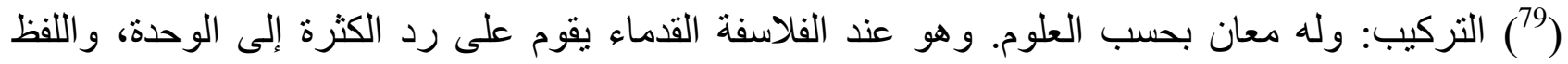

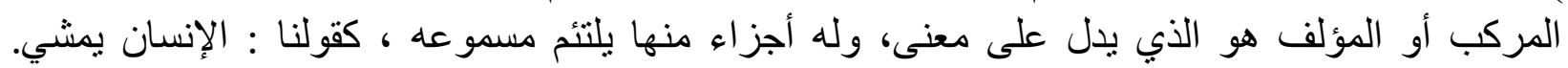

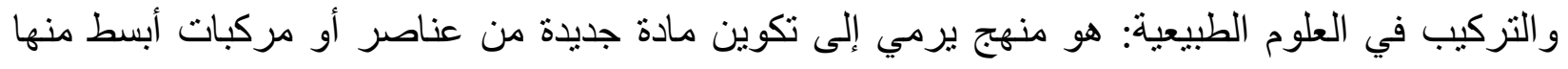

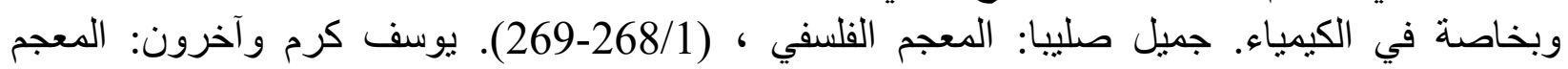

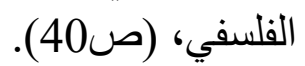

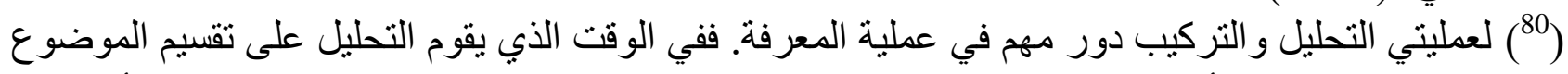

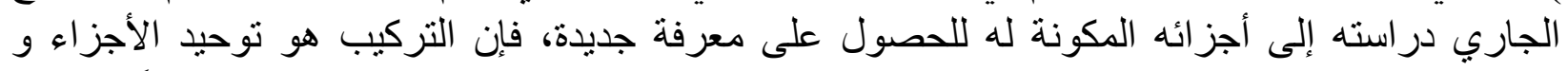

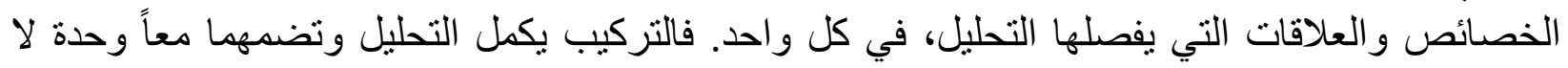

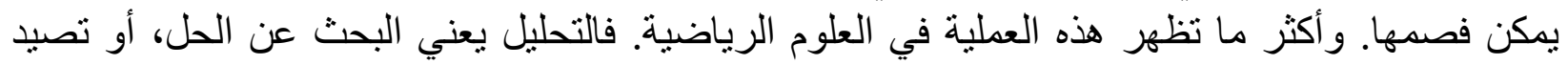

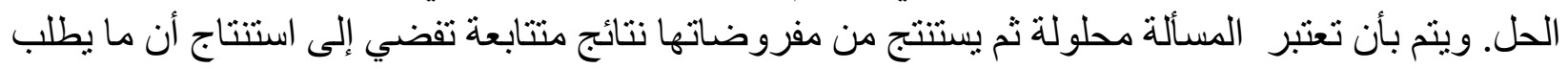

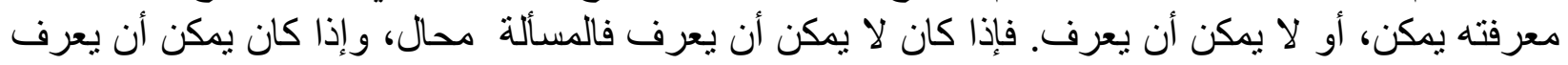

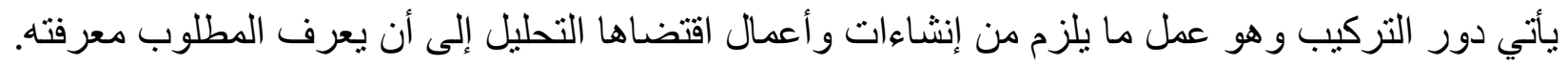

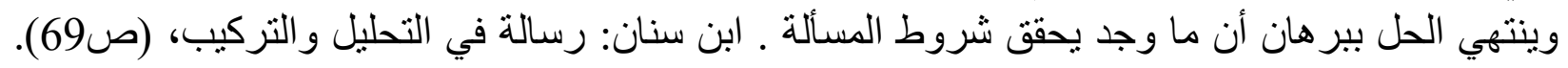

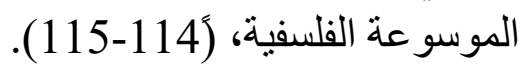




\section{المعرفة عند الصحاري}

أو لاً : موقفه من العقل كأداة للمعرفة

لقد كان الإيمان بكر امة الإنسـان، وبقيمته الذاتيـة، وبـاحتر ام عقله وحريته الفكريـة المنضبطة، من المبادئ و المرتكز ات التي قامت عليها حركة العلم ، وخاصـة العلوم التجريبية في الحضارة الإسلامية .

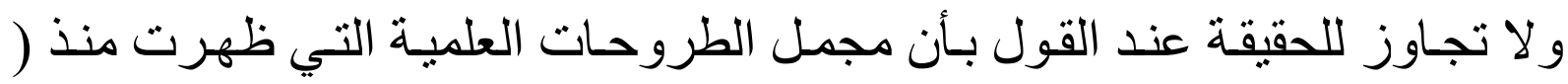

القرن الثاني الهجري / الثامن الميلادي ) ، وبخاصة عند المتكلمين- دفاعاً عن الدين -

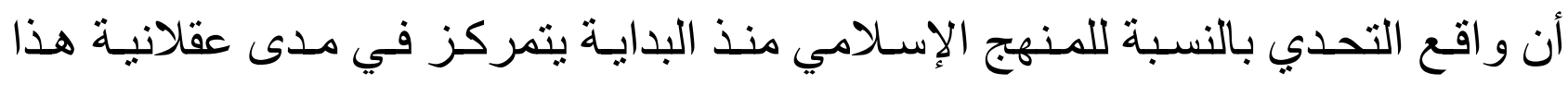
المنهج ومدى مسايرته للمطامح الإنسانية المتغيرة ؛ ممـا يعكس الطابع العقلاني الذي الذي

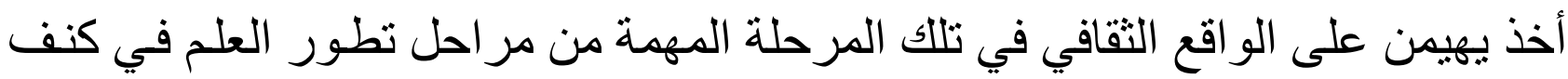

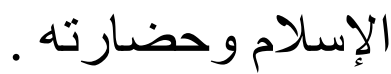

وليس من المقبول علمياً أن ندلف إلى الحديث عن العقلانيـة قبل التعريج على (

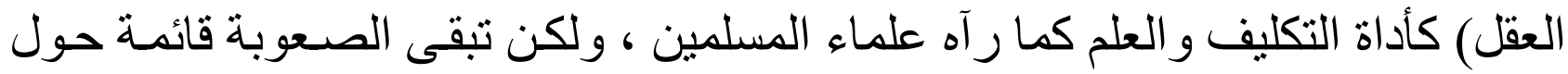

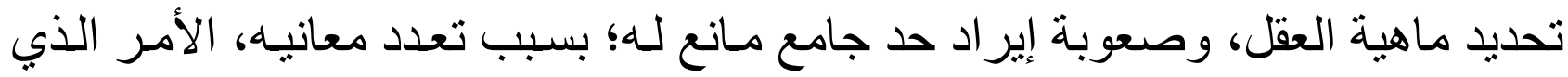

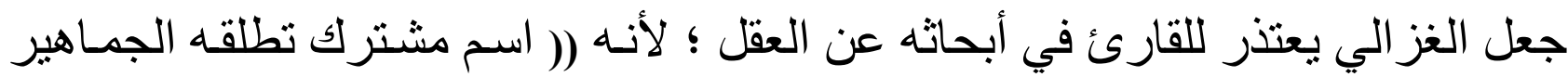

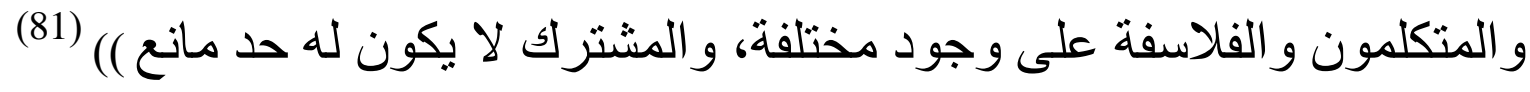


هذه الصعوبة بدأت مـع أقدم تعريف للعقل - في دائرة البحث الفلسفي / العلمي-

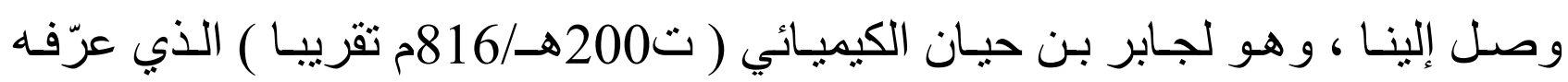
بقوله: (( العقل ... الجوهر البسيط القابل لصور الأشياء ذوات الصور و المعاني على لهى

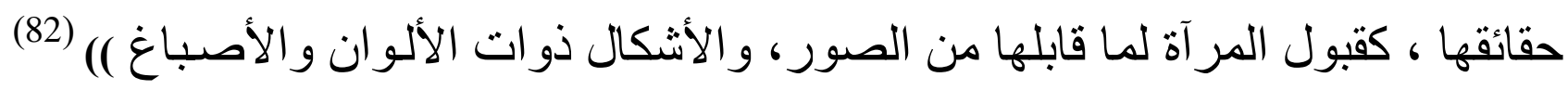
. وهو تعريف مادي أكثر منه فلسفي .

و ابن حيـان كمـا هو معروف يمثل خلاصـة التقاء العقلانيـة ( الكلاميـة والعلميـة

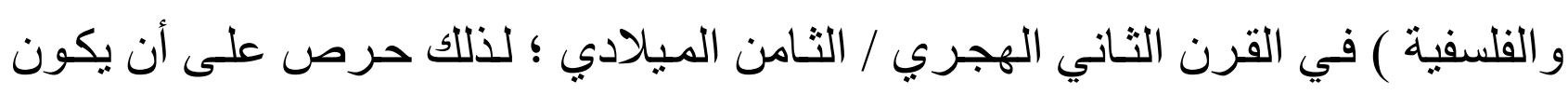

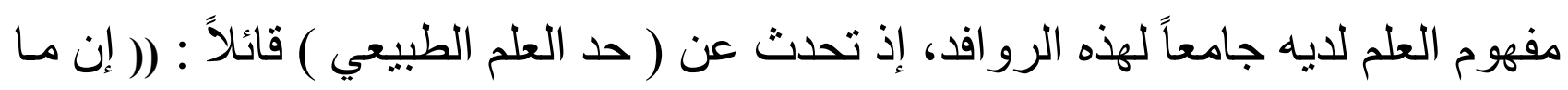

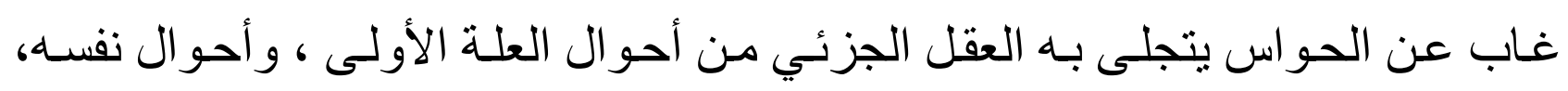

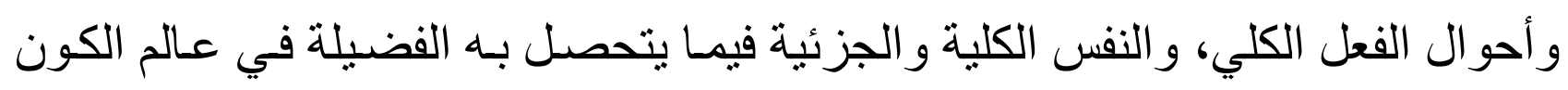

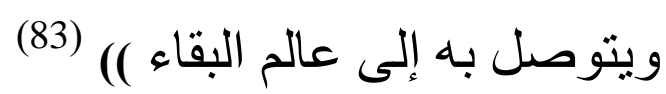
و لا نريد حقيقة أن نقف طو يلا أمام المعنى اللغوي للعقل عند العرب، وهي واهي واحدة

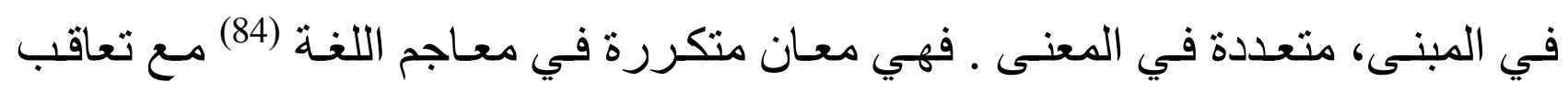

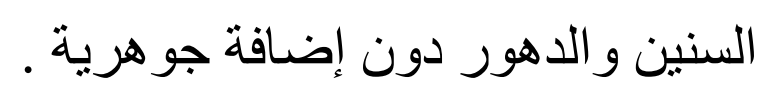

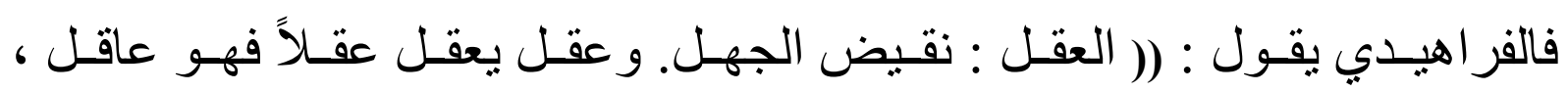

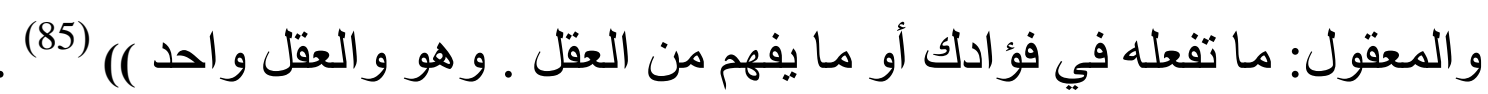

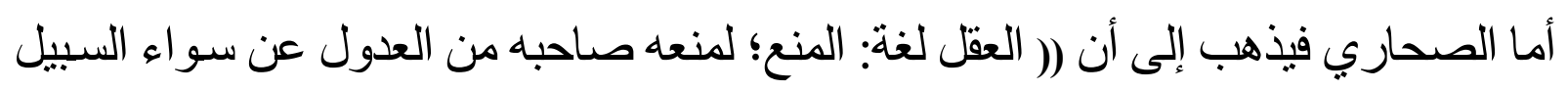

أمـا المعنى الاصطلاحي للعقل ـ و هو مـا يهمنـا في قضـية التفكير العلمي - فإنـه

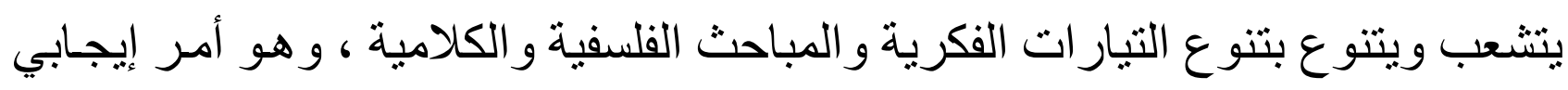

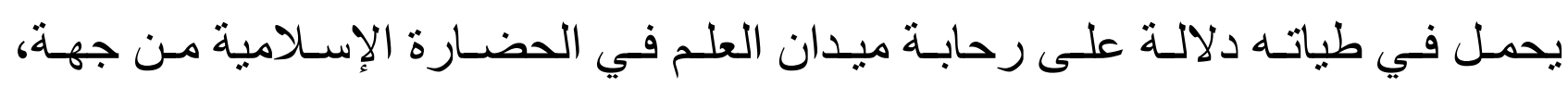

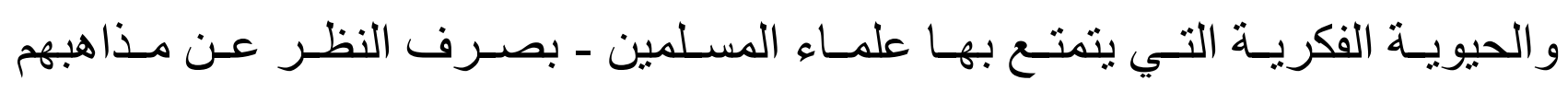
و اتجاهاتهم- في تناولهم لقضايا العلم بو اسطة آلته ( العقل ) من جهة أخرى.

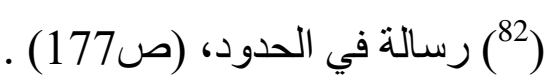

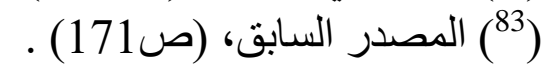
(84) انظر: (بن منظور : لسان العرب، (458/11-466). الرازي: مختار الصحاح، (ص393-394) .

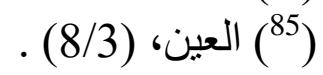

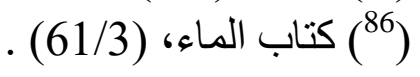




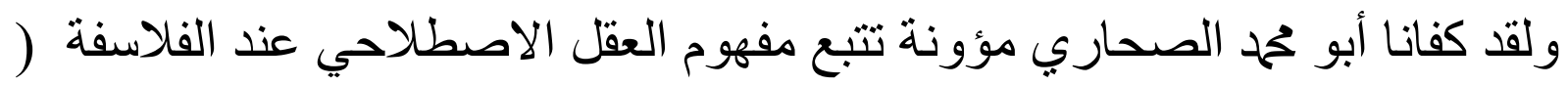

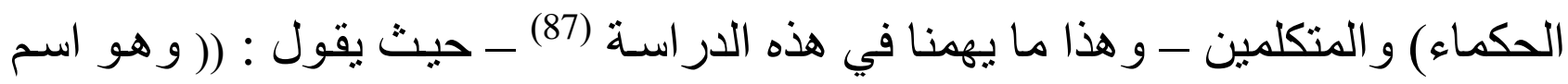

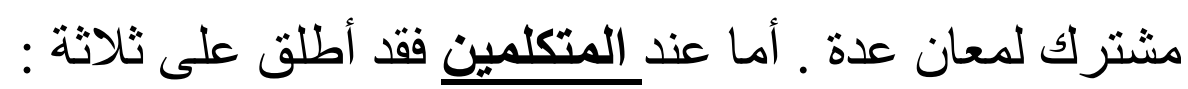

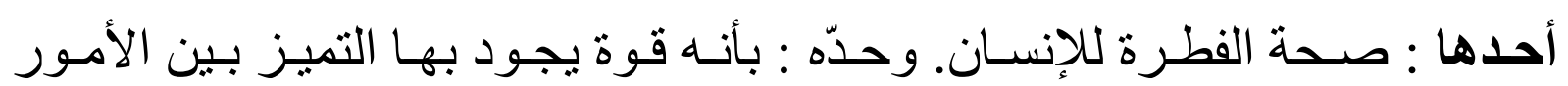
الحسنة و القبيحة . ثانيها: ما يكسبه الإنسان بالتجارب من أحكام الله ـ وحدّه : بأنه معان مجتمعة في

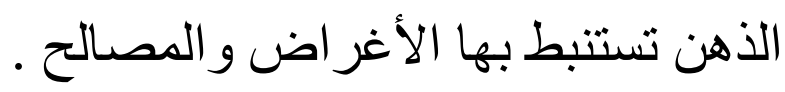

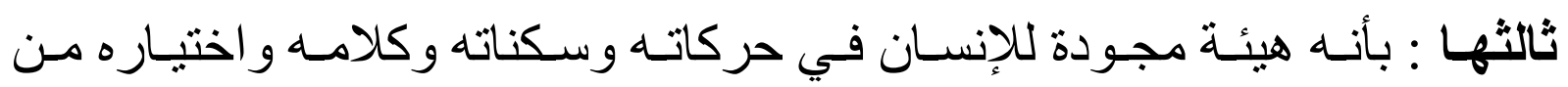
الجزئيات من أجل غاية مظنونة أو معلومة .

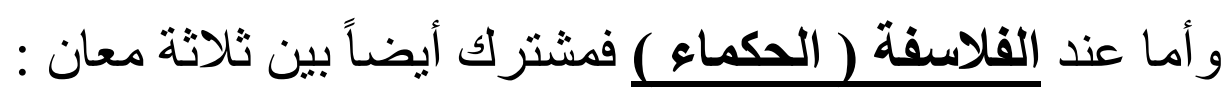
الأول : العقل النظري : وهو قوة للنفس الناطقة تقبل ماهيات الأمور الكلية من جهة ما هي كلية . الثاني : العقل العملي : وهو قوة للنفس ، وهي مبدأ القوة الثنوقية إلى ما يختار من الجزئيات من أجل غاية مظنونة أو معلومة . الثالث : أن يطلق على واحد من العقول العشرة ) (88)

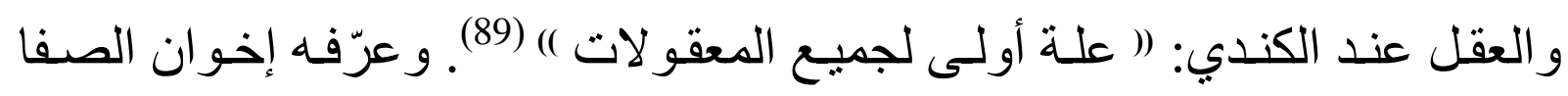
بأنه: (( قوة من قوى النفس الإنسانية التي فعلها التفكير و الرؤيـة و النطق و التمييز ) )

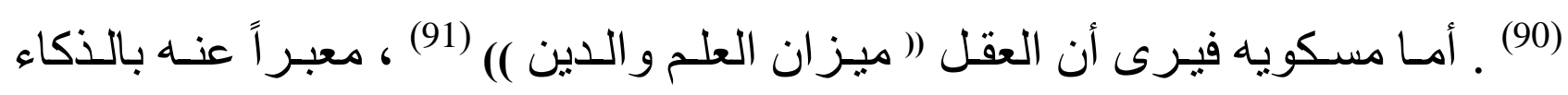
و التذكر و التعقل وسر عة الفهم وقوته وصفائه، وسهولة التعلم. ويفرق بينه وبين التعقل

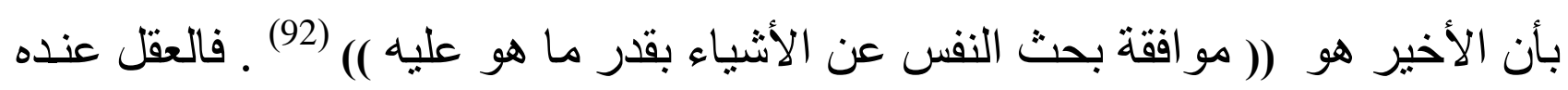
(أتأتي أهمية الاقتصار على الفلاسفة والمتكلمين ؛ لأن المشتخلين بالعلوم التجرييية يصنفون بين هاتين الفيتنين

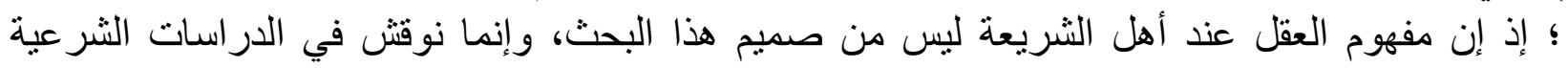

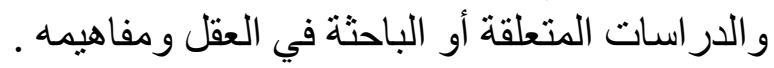

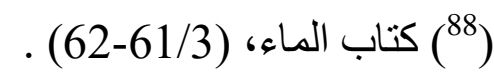

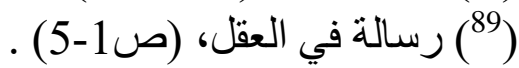

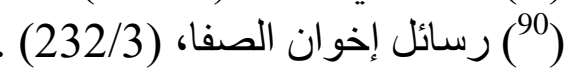

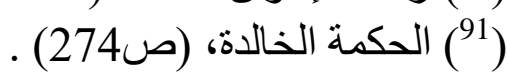
(274) (274) ( 
إذاً سلاح الإنسان العاقل؛ (( إذ لا يعقل الإنسان الثيء إلا بعد التفكير و التطلب و التميز أما الجرجاني فقدم لنا ثبتاً بحدود مفاهيم العقل المتداولة بين الفلاسفة و المتكلمين و اللغويين ، ويقول : (ر العقل: مأخوذ من عقال البعير ؛ يمنع ذوي العقول من العدول

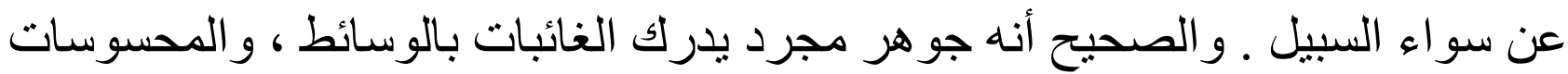

إن عناية العلماء بالمفاهيم الخاصة بالعقلانية أو تنظوي تحت ظلالها يحمل في

طياته أهمية الأمر بالنسبة لهم. فحديثهم عن مصطلحات: الفكر، و الذهن، و الفطنة ...

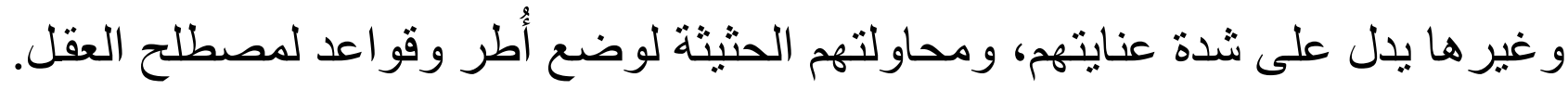

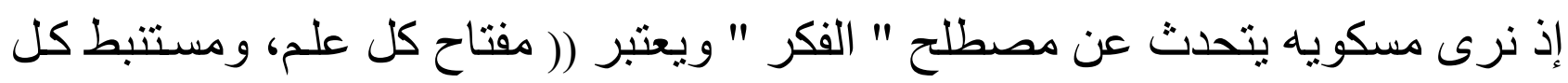

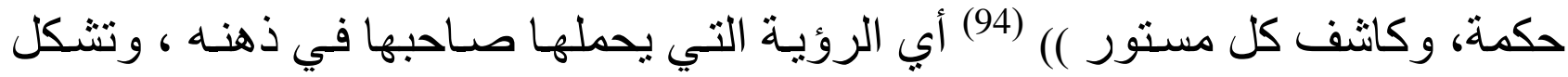

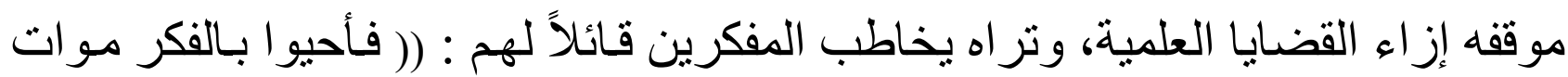

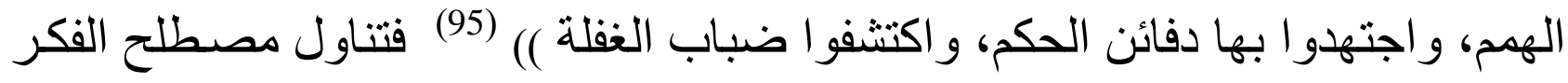
بثـيء من التوسع و المقارنـة بين تعريف اللغويين و التجريبين و الفلاسفة ليكتمل بنـاء المصطلح حيث يقول : (الفكر : وقد يقال: الفكَر هو حركة ذهن الإنسـان فيما

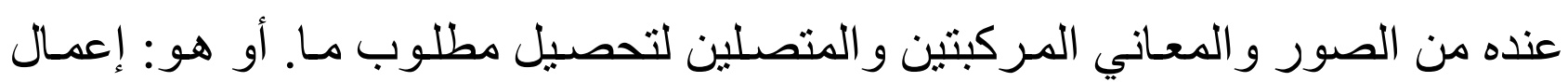

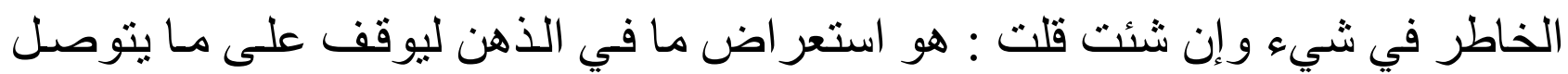

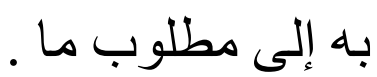

وعن الكندي : الفكر : حركة ذهن الإنسان في المبادئ ليتوصل بذلك إلى المطالب.

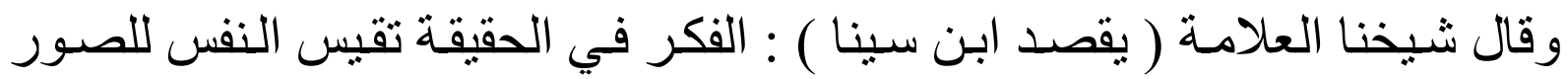

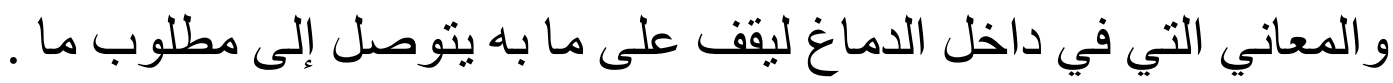
وقال سيبويه : لا يجمع الفكر ولا العلم ولا النظر )( ل) (96)

(27) مسكويه : تهذيب الأخلاق، (27) . (94 (95 مسكويه: الحكمة الخالدة ، (ص291) (291).

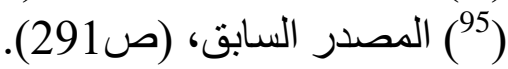
(158-157/3) الصحاري: كتاب الماء) (صناء) 
ثم نر اه يناقش مصطلح ( الذهن ) ومفهومه عند أهل اللغـة والفلسفة فهو عند أهل

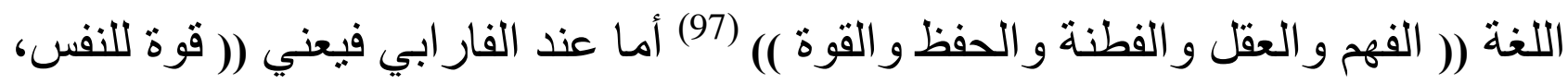

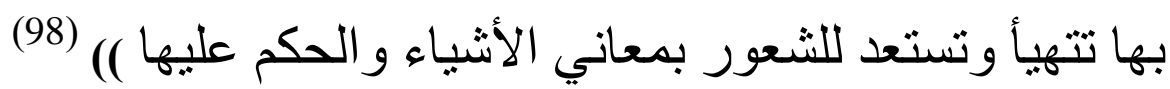

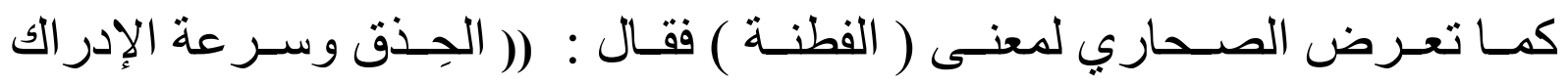
وسر عة الثعور )) (99) ثم يأخذ في الحديث عن الفرق بين الإدراك و الثـعور وصلتهـيا

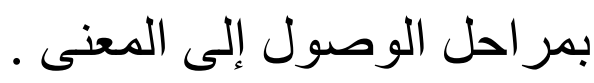
ولقد نوّج ابن خلدون جهود الدفكرين الذين سبقوه بأن سار بالنز عة العقلية ــ التي التي

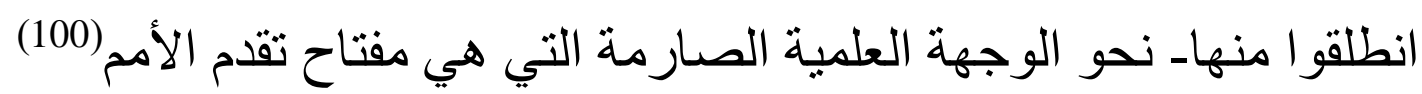

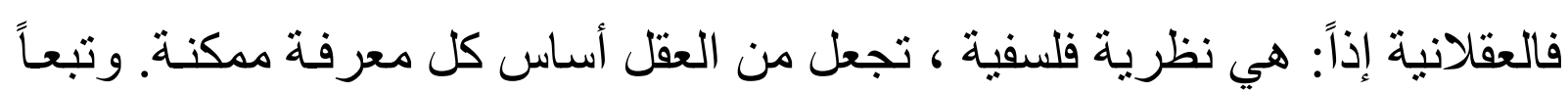

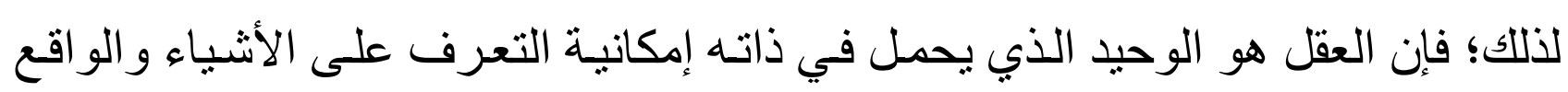

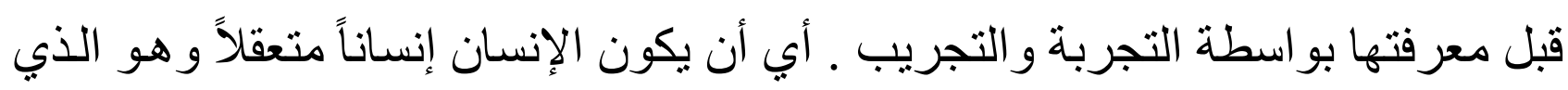

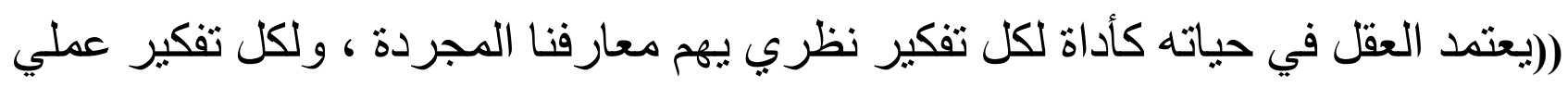

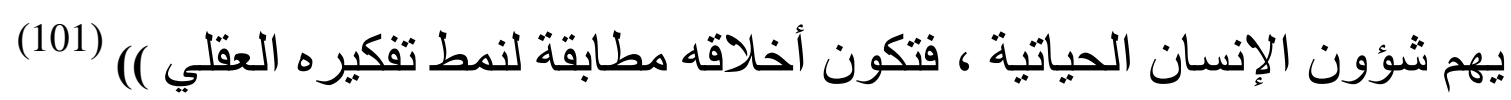

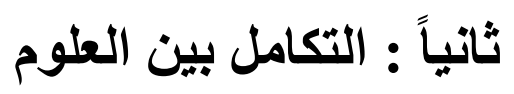

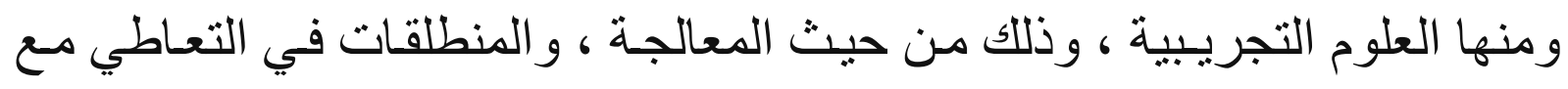
النص العلمي ، و هو ما لفت انتباه البيهقي (ت

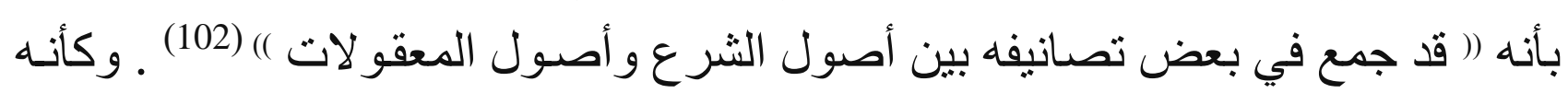

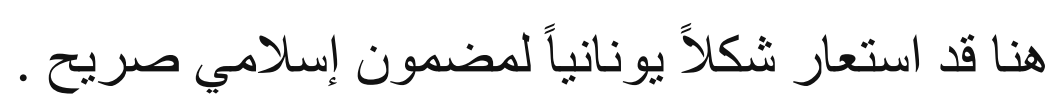

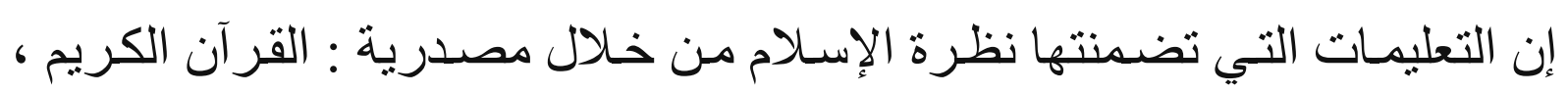

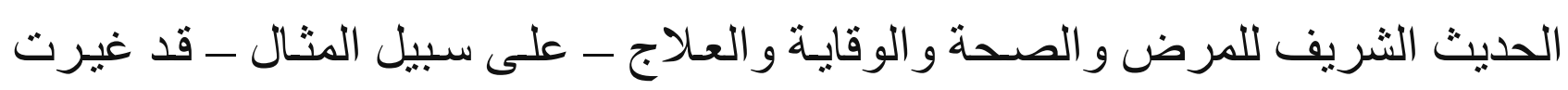

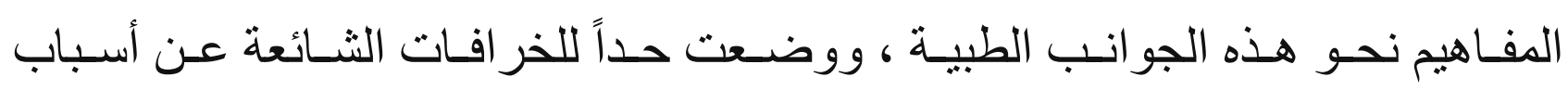

$$
\begin{aligned}
& \text { (97) المصدر السابق، (116/2) . } \\
& \text { (198) المصدر السابق، (117/2) (117/2) . }
\end{aligned}
$$

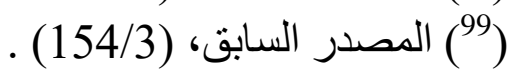

(100) ابن خلدون : المقدمة، (ص34). حامد خليل : النزعة العقلية في الفلسفة العربية ( مقال )، (ص134-

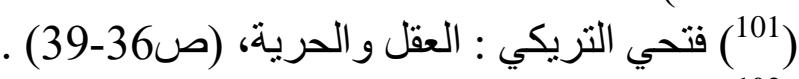

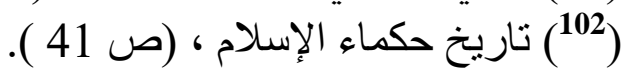


الأمر اض ووسائل علاجها ، ووضعت علماء الطب على الطريق الصحيح ليبحثو افي الداء و الدو اء ليعلم من لم يكن يعلم (103). ومع معرفة الأطباء بنظريـة أرسطو في السبيبة فقد أهملوهـا وأخذوا بالنظريـة

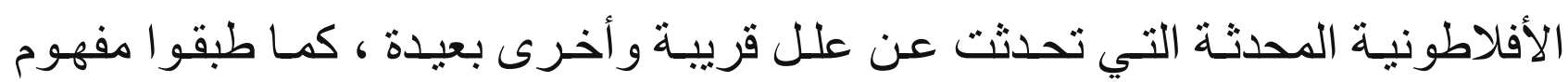

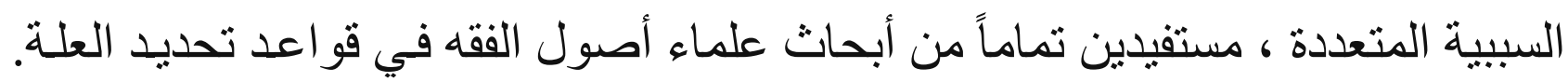

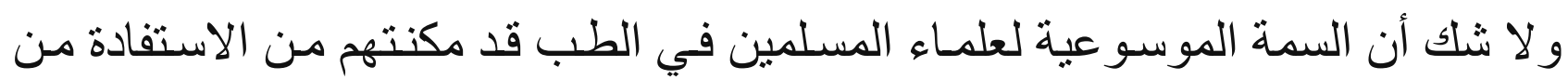

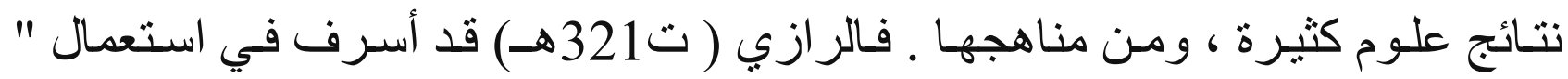

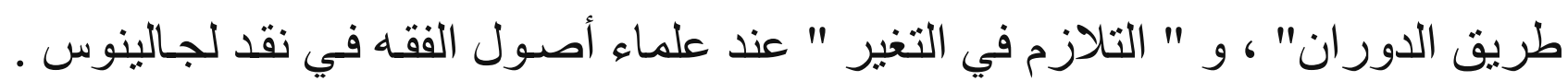

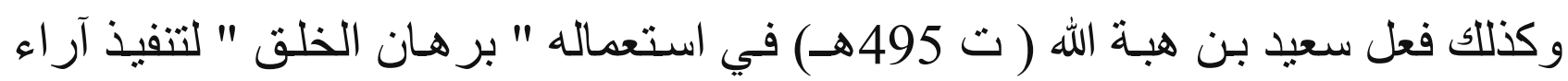
القدماء في قضايا كثيرة(104)

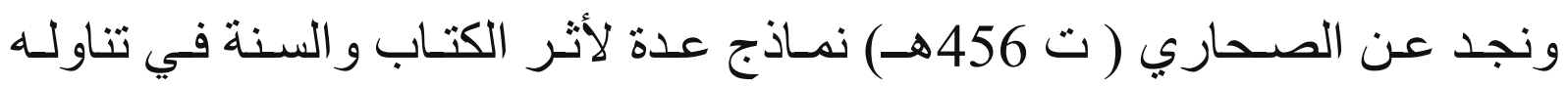

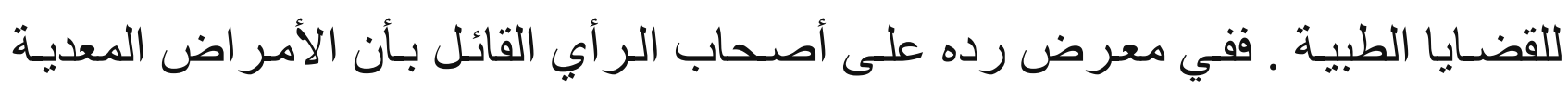

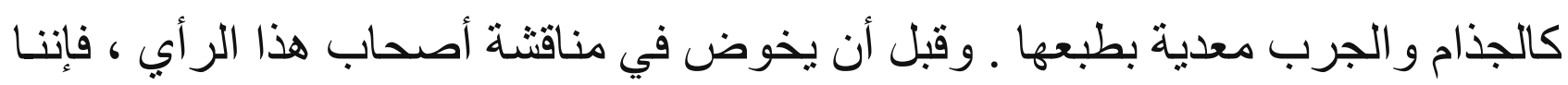

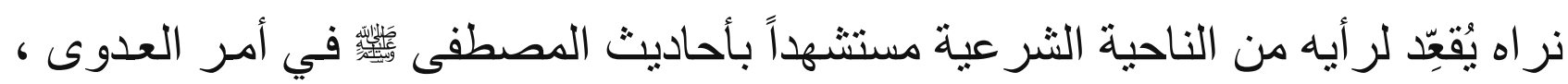

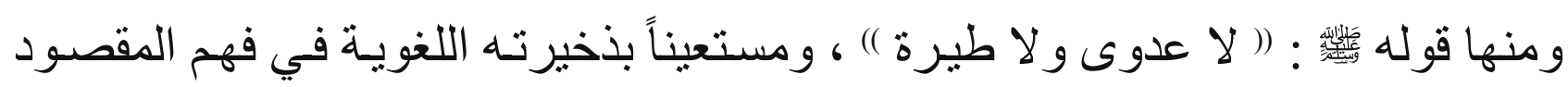

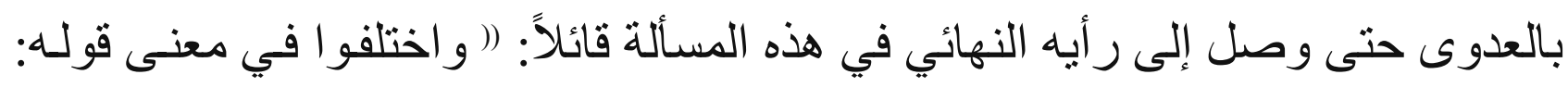

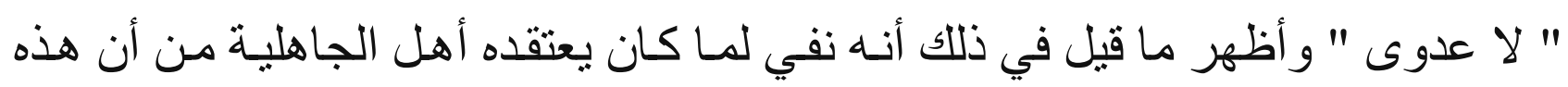

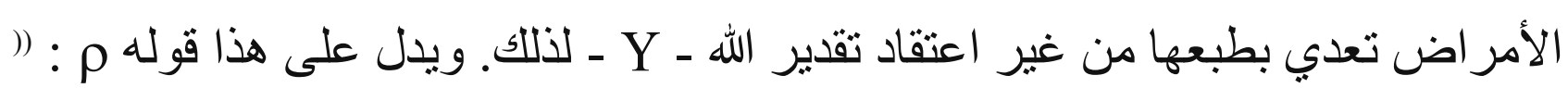

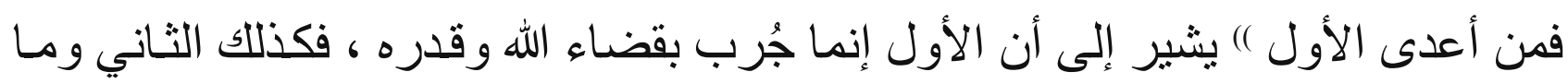

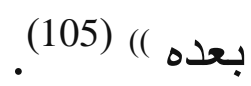

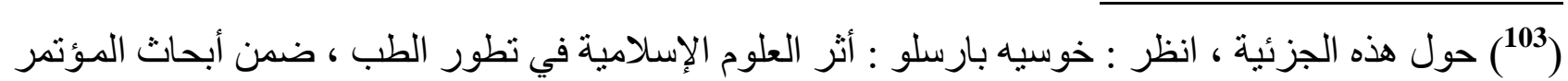

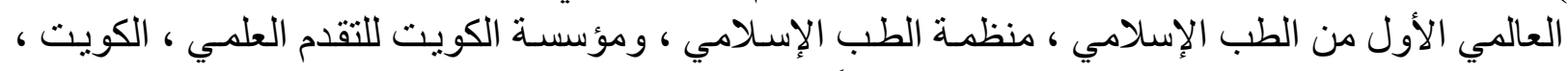

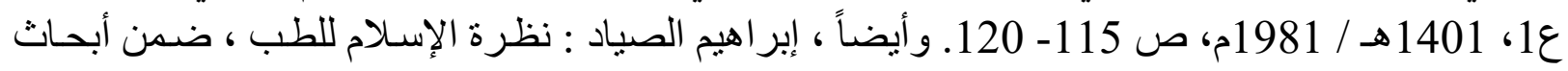

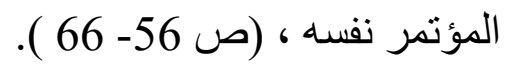
(104) سحبان خليفات : مناهج المعرفة الطبية عند الأطباء العرب والمسلمين ، محاضرة ألقيت في معهد التراث

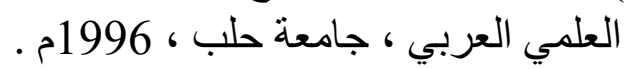

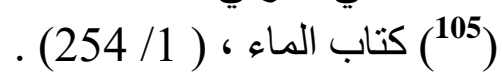




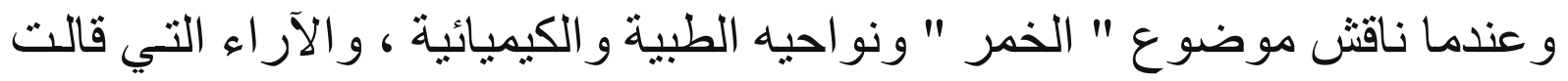

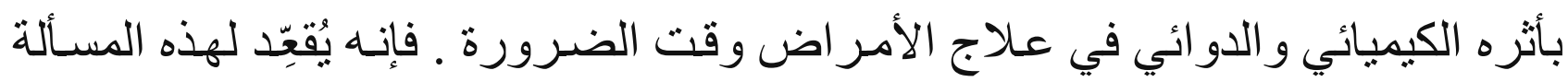

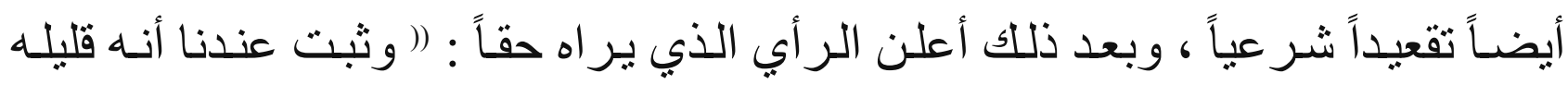

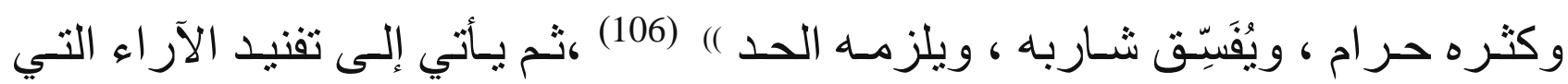

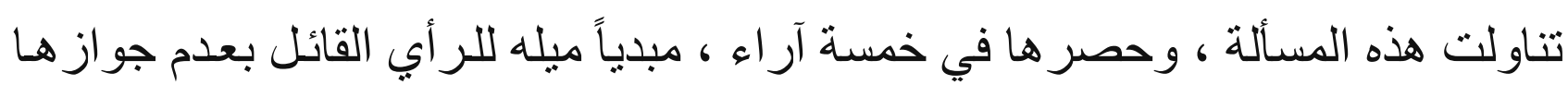

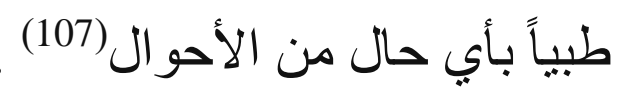
ويبقى عمل أبي ححمد الصحاري( ت 456هـ) المتمثل في كتابة " الماء" ، الأبرز

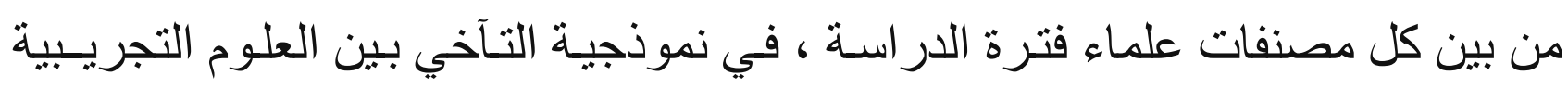

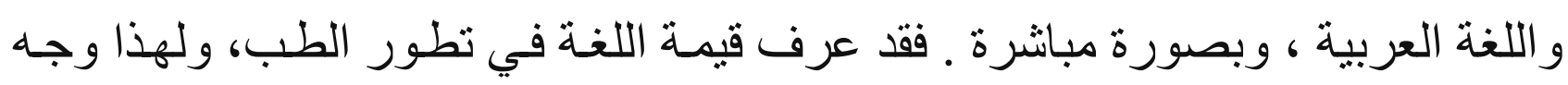

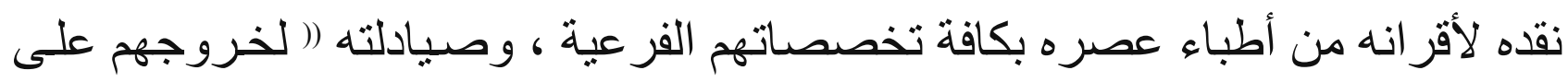

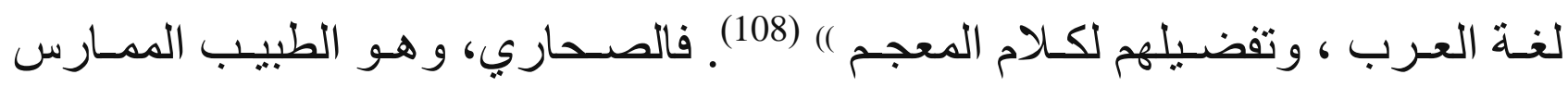

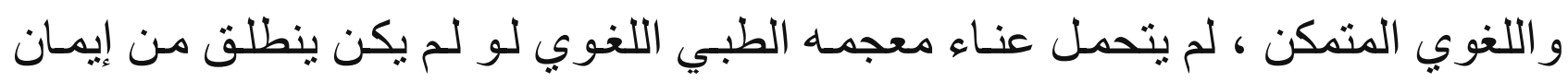

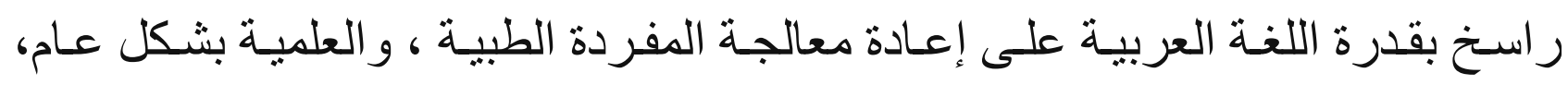

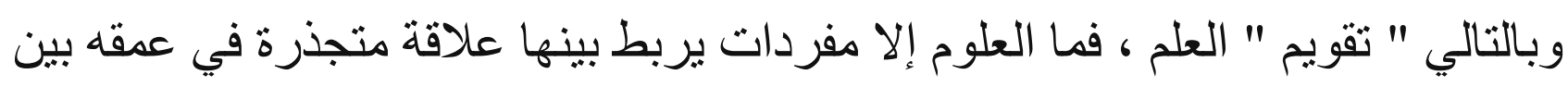

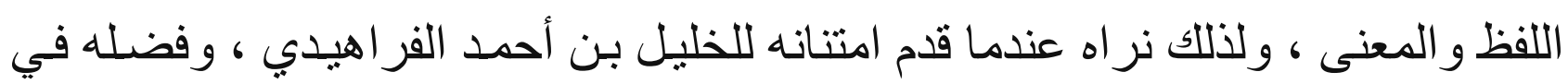

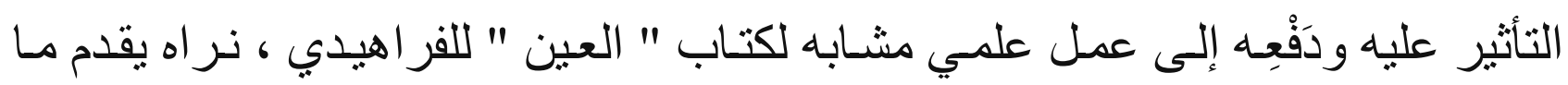

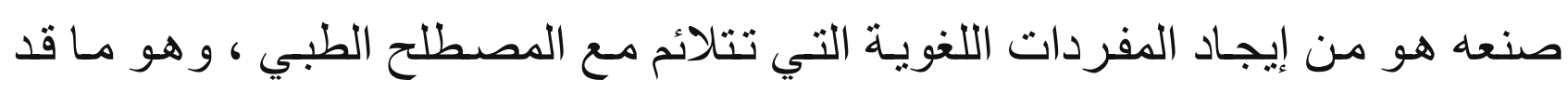

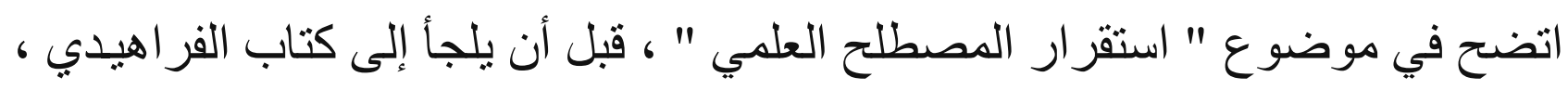

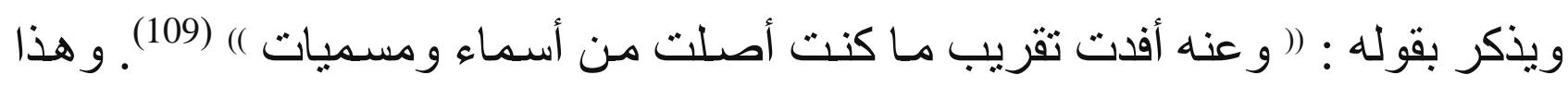
التأصيل منه قد ألزمه ـ كما يقول هو - ذكر (( أسماء النبات ، و والحيوان ، و وأعضـاء

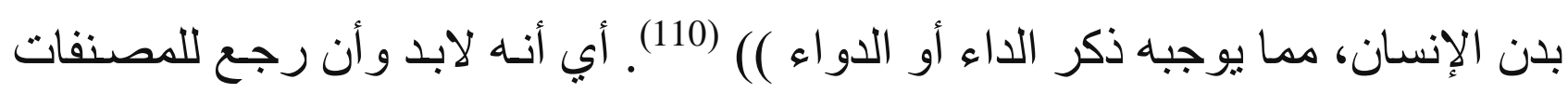

(106) المصدر السابق ، (43/3) ـ بالطبع الصحاري لم يأت بجديد في هذا الأمر ، و إنما قصده بسط الأمور

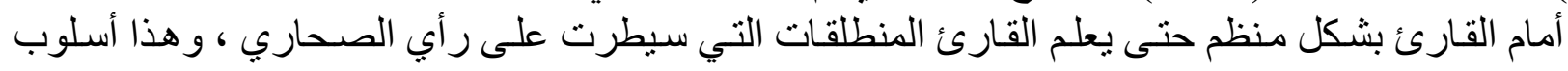

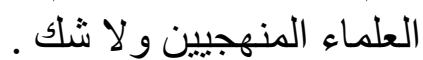

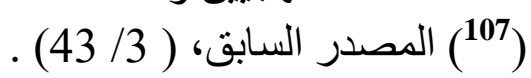

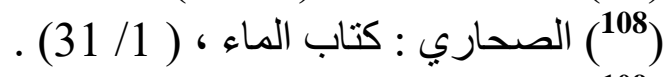

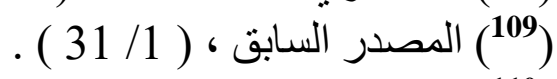

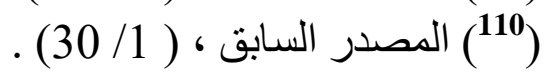


التي وضعها علماء العربية في تلك الموضو عات ، وهي كما ر أينا بالعشر ات، وهو مـا

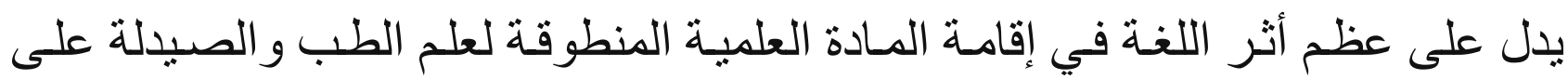
وجه الخصوص عند الصحاري .

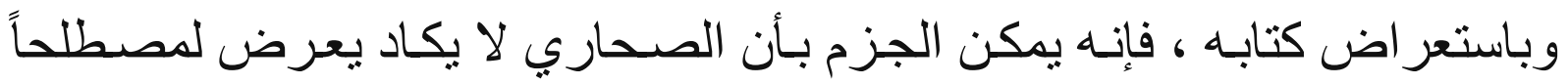

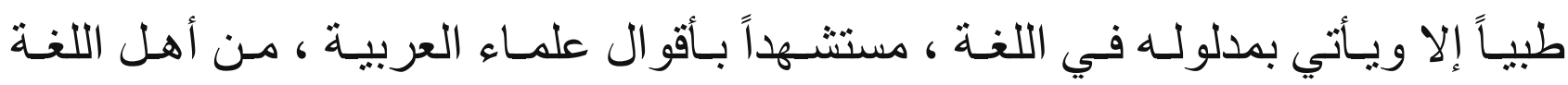
والأدب(111.) ومن شدة التزام الصحاري بهذا المنهج ، فإن القارئ قد يذهب بـ بـه تفكيره

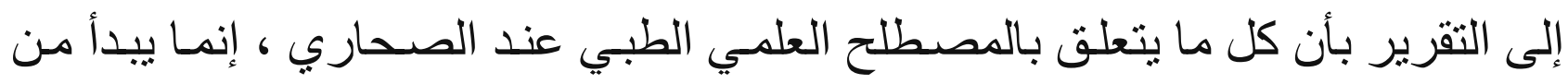

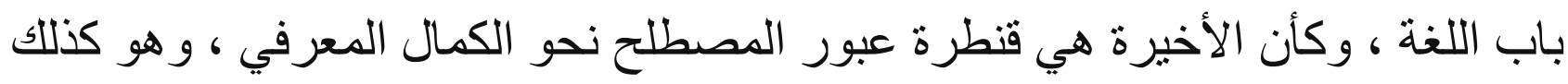
بالفعل عند الصحاري.

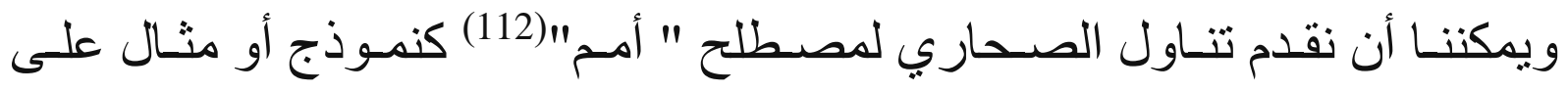

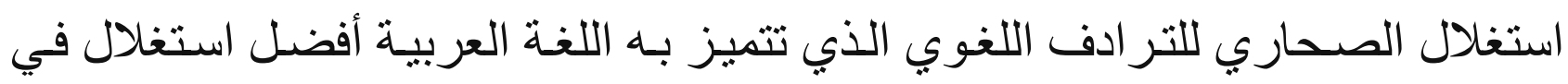

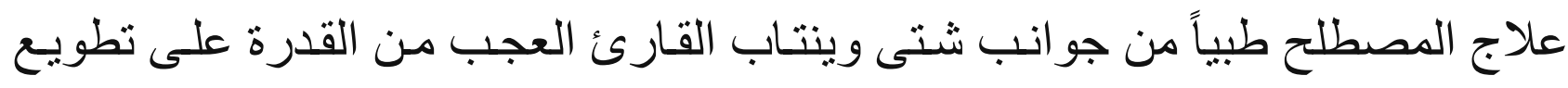
المفردة اللغوية للمصطلح الطبي بكل هذا التمكن . و اتخذت استعانة الصحاري بالجانب اللغوي صورة أخرى تجاوز فيها الاعتمـاد

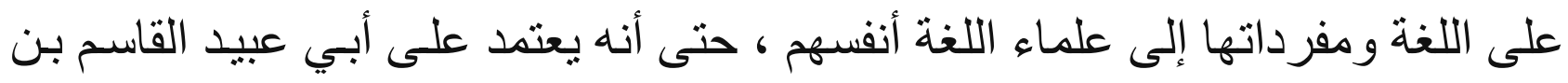

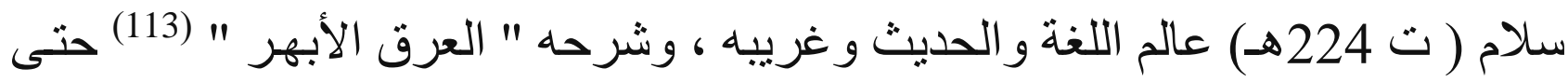

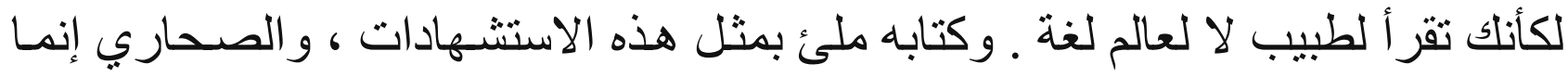

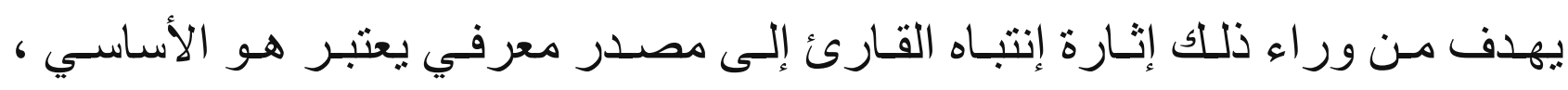
باعتباره يتعلق بلغة العلم التي كتب بها ، بغض النظر عن صحتها من عدمها ، ولهذا

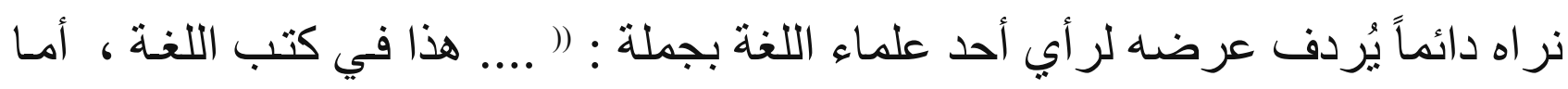

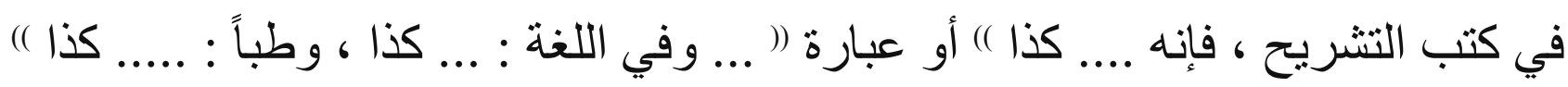

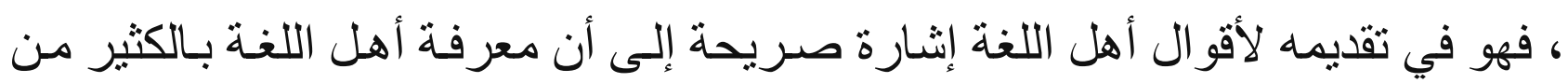
المعارف الطبية أسبق من الأطباء أنفسهم ، فهم بذللك قد وجدو ال متكأ علمياً في بدايـة

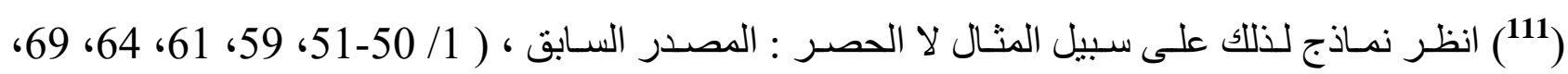

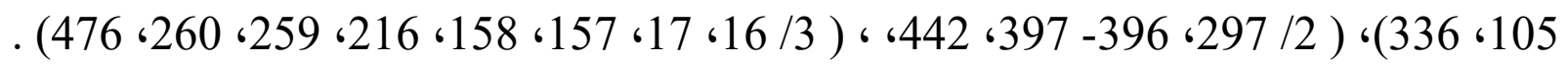

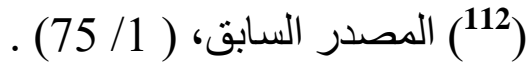

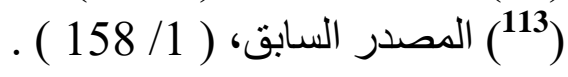


عملهم. و الصحاري هنـا ، بـلا شـك ، إنمـا يؤر خ للمصطلح العلمي ، وبالتـالي للمعرفـة الطبية .

ثم إن اللغة و غناها اللفظي كانت المعين الذي يفزع إليهه الصحاري في مواجهة خصومه العلميين ، وفي نقده للآر اء التي يعرض لها في كتابه ، وخاصـة المتكلمين و الفلاسفة . فعندما ناقتت آر اءهم المتعلقة بتحديد موضع الدماغ ، وقولهم بأنه مستقر في القلب ، مستشـهدين بقولـه تعـالى :

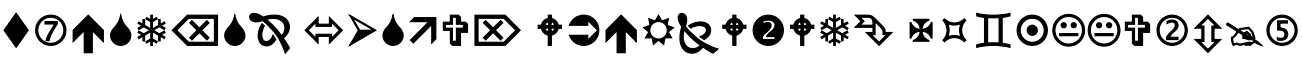

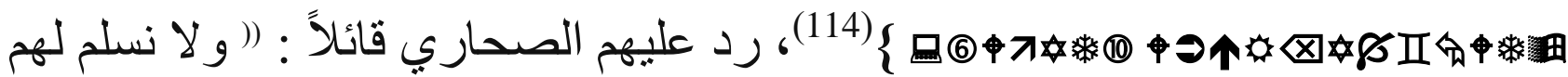
بذلك، لأن الآية جارية على مجرى كلام العرب، فهم يطلقون القلب على القلب و العقل ، كمـا أطلقوا الكبد على الكبد و القلب ـ وهم لا يقصدون الآلـة المسماة بـللك ، ولكنهم يريدون الأحاسيس و العاطفة ، وكل ذللك لا يكون إلا من العقل الذي مستقره الدماغ ،

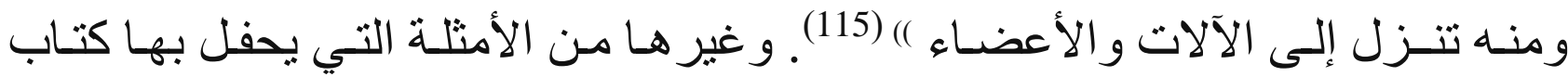

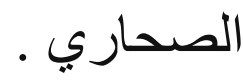

\section{علاقة الفلسفة بالعلوم التجريبية}

كان لحركة الترجمـة - وكمـا سبق أن ر أيناـ الآثار البعيدة في تعريف المسلمين

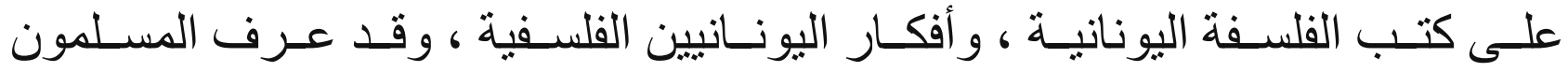

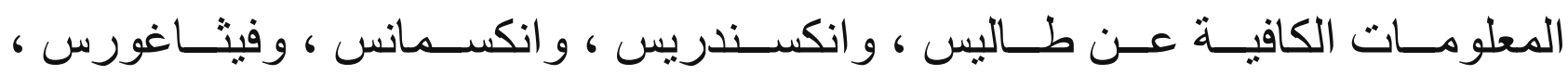
وديموقرطس ، وكذلك كانت لهم معرفة واسعة بأفكار سقر اط ، و أفلاطون ، وأرسطو أنثهر فلاسفة اليونان عند المسلمين . ولسنا هنا بصدد الحديث عن موقف الإسـلام من الفلسفة اليونانيـة ، فذللك مجـال لا يهينا في دراستنا هذه، و إنما نحن هنا نحاول العثور على نقاط التماس ، أو قل التنقيب

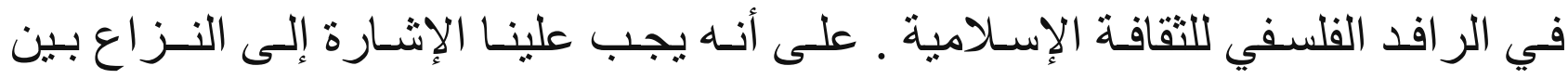

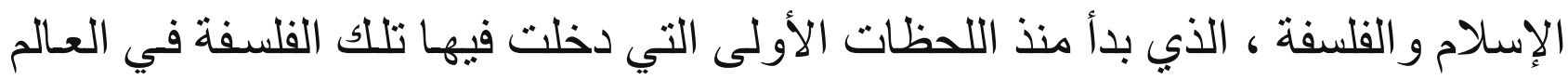




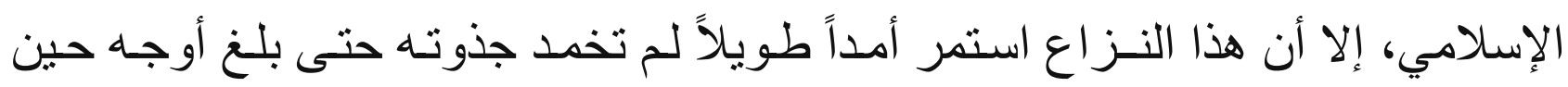
أعلن الغز الي تكفير فلاسفة الإسلام أنفسهم باسم الإسلام.

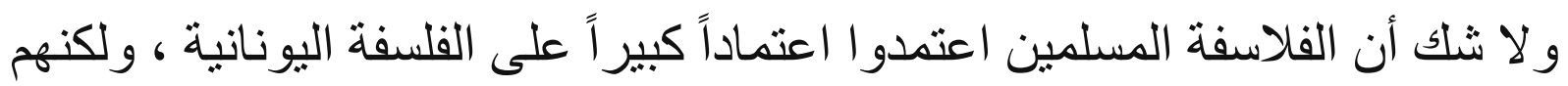
وفقو ا إلى بعض الابتكار ات و التجديدات في أبحاثهم الفلسفية ، إذ علمنـا أن الاتصـال

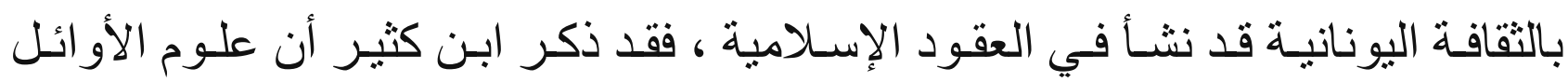

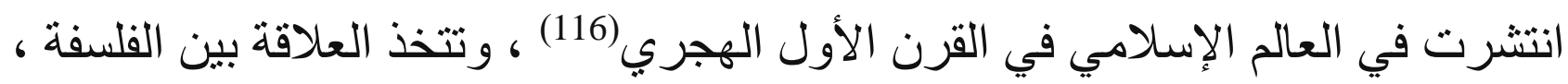
وموضو عاتها الثلاثة : المنطق ، و الطبيعيات ، و علم الأخلاق، وبين العلوم التجريبية

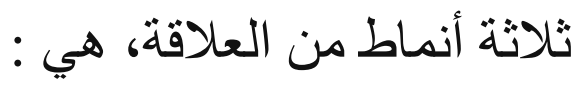
وظل الموقف مـن الفلسفة نفسـه عند أبي محمد الصـحاري (ت 456هـ) ، عندما اعتبر العلماء التجريبيين فلاسفة ، ولذا نجده حريص كل الحرص على الإتيان بآراء الفلاسفة، كلما كان هنالك صادر عنهم في موضع معين كقوله : (و عند الفلاسفة ...كذا ) )

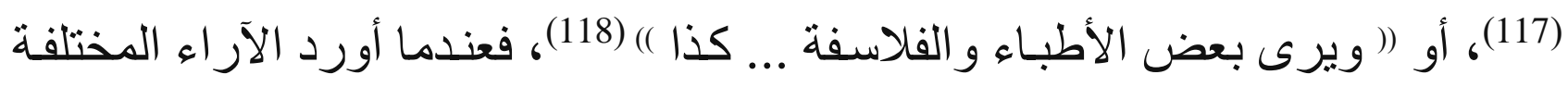

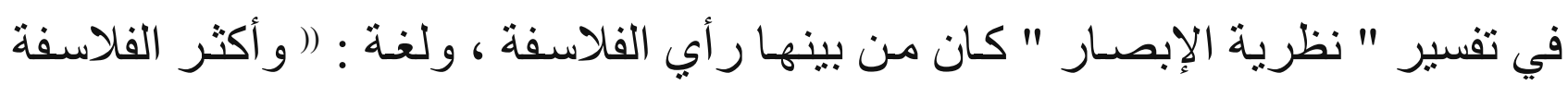

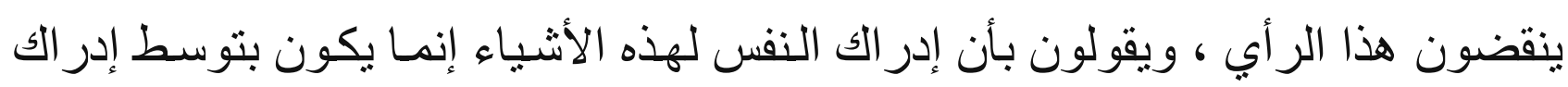

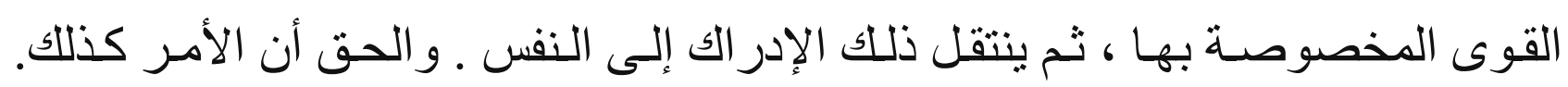

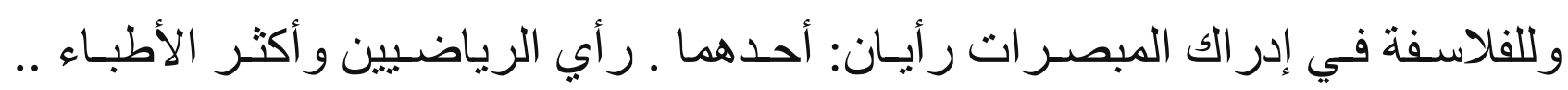
وثانيها، رأي أكثر الطبيعيين ، ....)، (119).

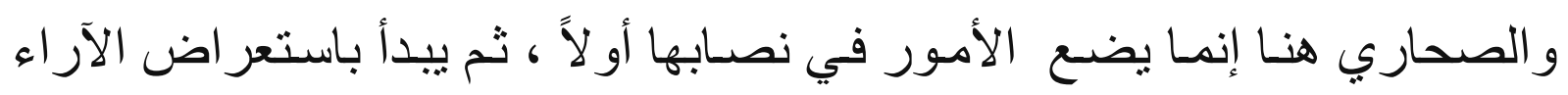

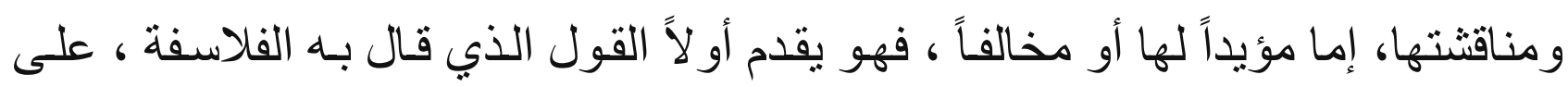

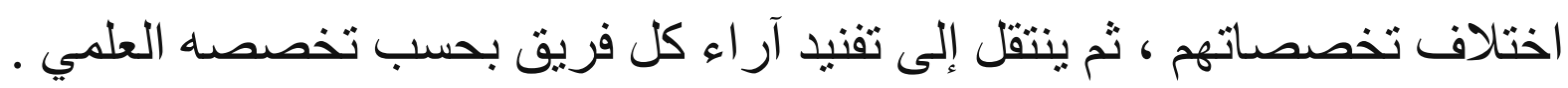

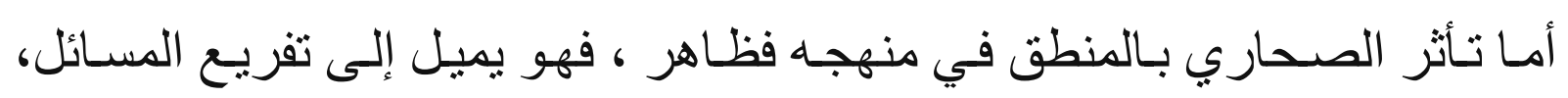

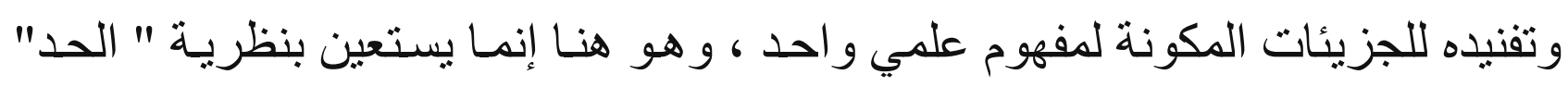

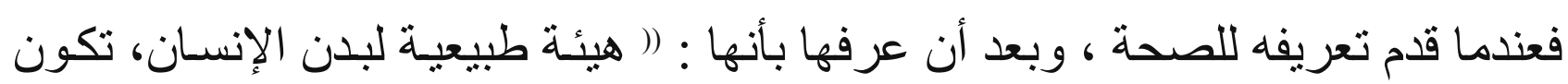


الأفعال كلها بها سليمة ) ، أخذ في بيـان حد الجزء وصو لاً للمعنى الكلي المقصود،

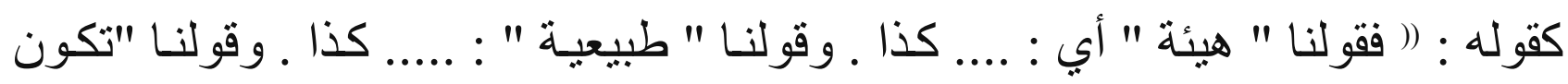
الأفعال " ... كذا ، .. الخ ) (120).

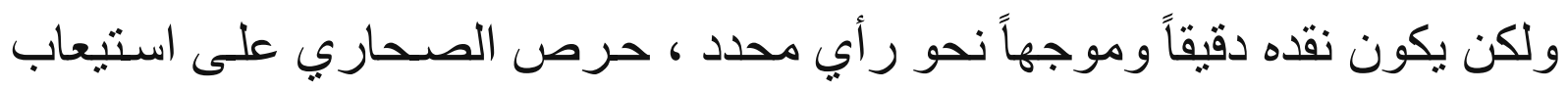

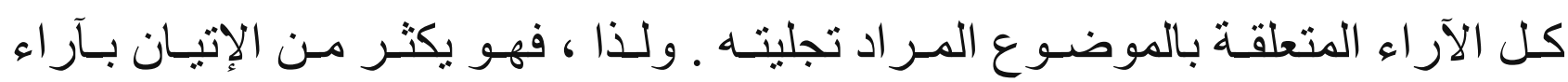

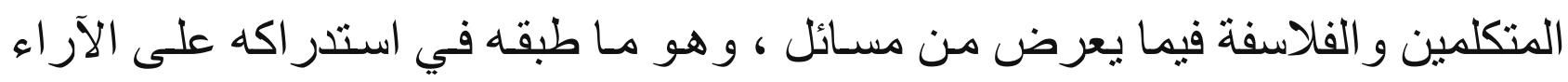
التي تعرض لموضوع " العقل " وهي آراء المتكلمين ومعهم الفلاسفة ، فوجه سهام نقده

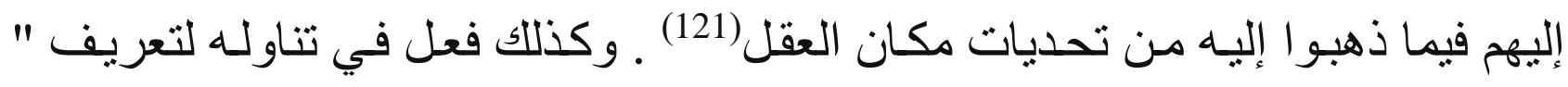
العلة "(122)، ومناقشته أيضاً لمصطلح " القوة " (123)

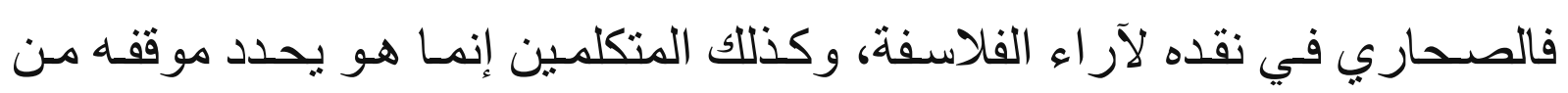

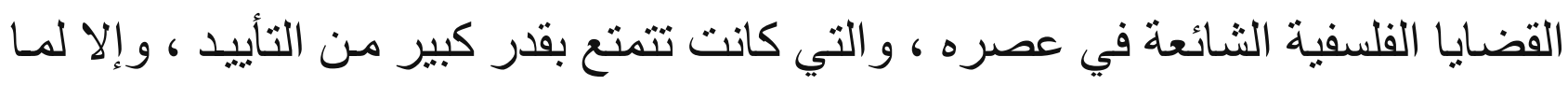
حرص الصحاري على تضمينها كتابه .

\section{التفاعل بين العلوم التجريبية بعضها ببعض فلرابه}

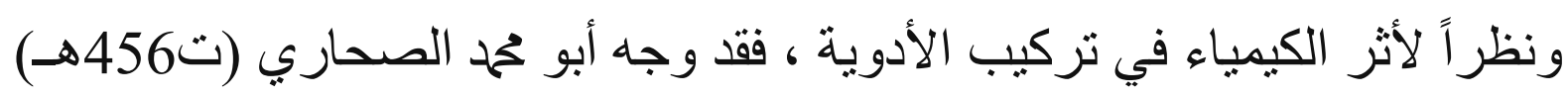

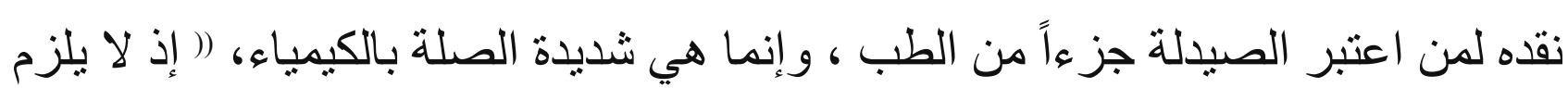

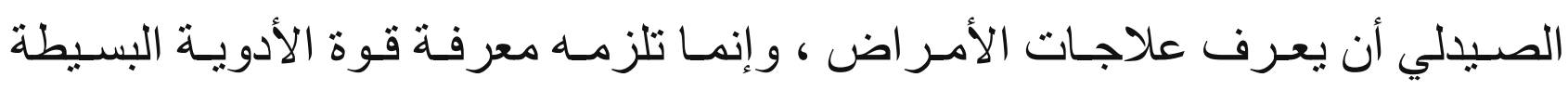

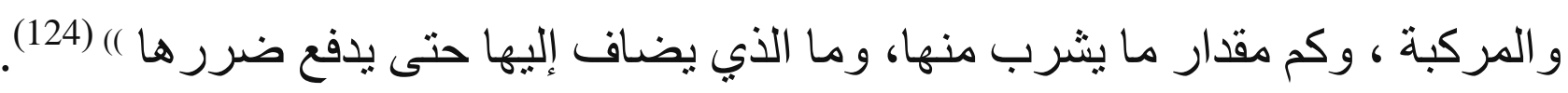

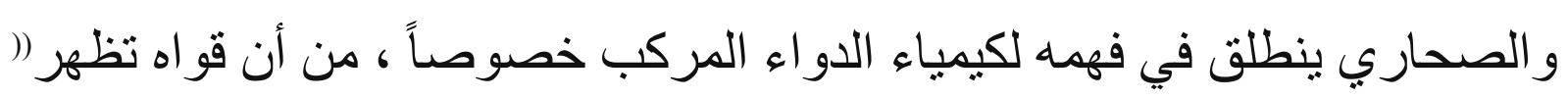

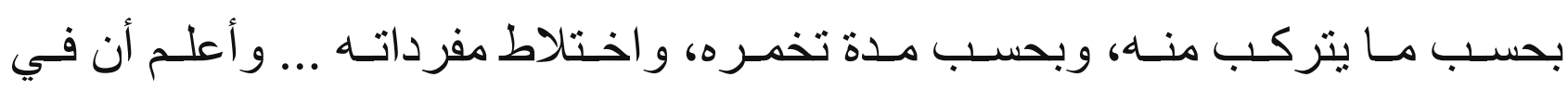

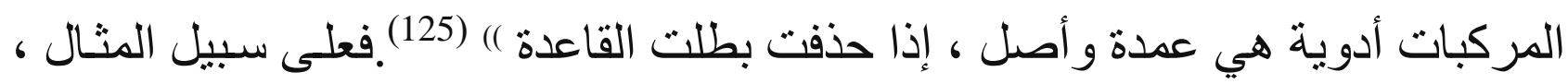

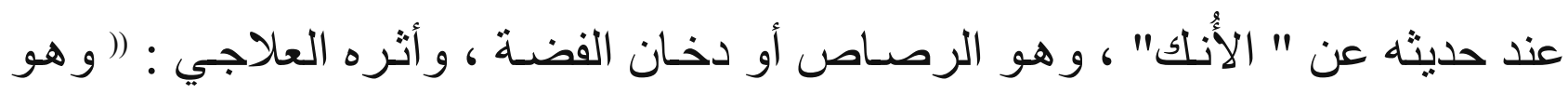

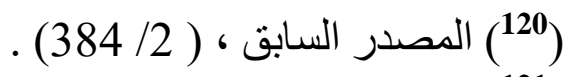

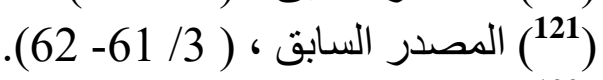

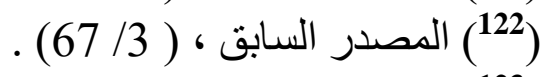

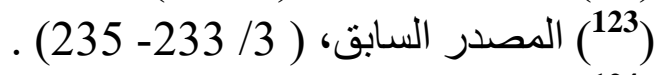

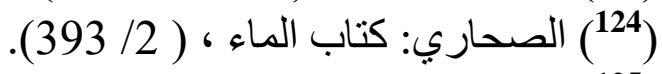

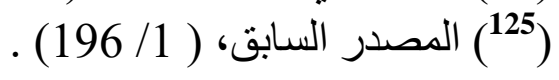


عمدة في المر اهم ، وسُم قاتل من داخل )، (126.فهو يدرك أن تحضير الدواء لابد وأن يكون بمعايير محددة ، الأمر الذي دفعه إلى التحذير عند تحضير " الحنظل " كدواء ،

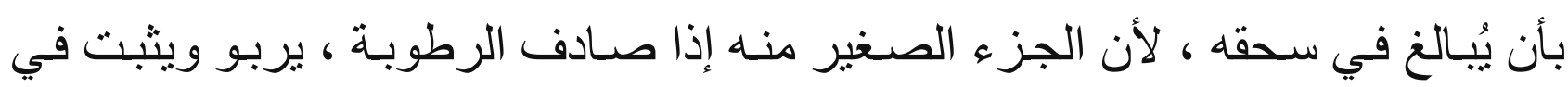

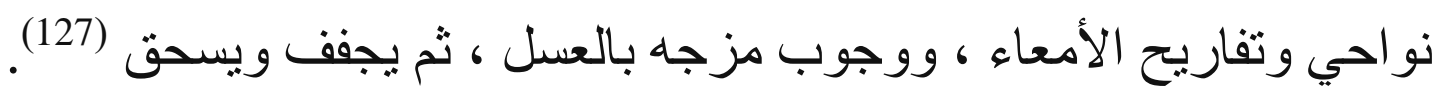

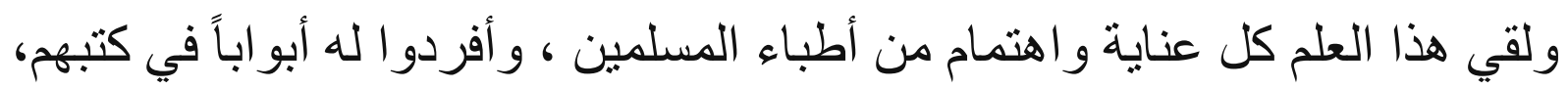

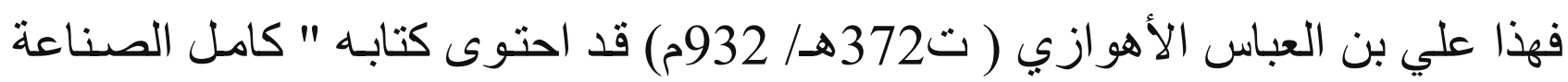

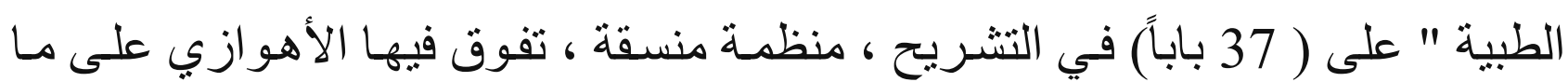
أورده العديد من الأطباء في هذا الباب . وخص ابن سينا (ت 428هـ) التشريح في كتابه " القانون " بفصول طويلة ، جمع

فيها كل المعارف السابقة في هذا الفن . ومما يشير إلى انفر اد هذا العلم عن الطب ، ووجود علماء في التشريح خاصة ،

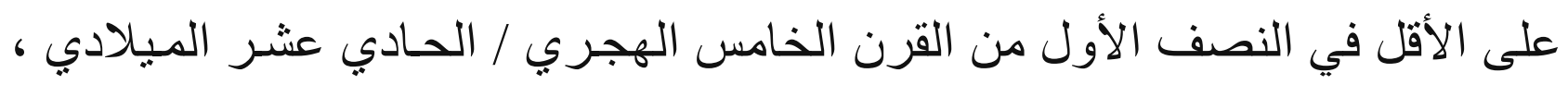

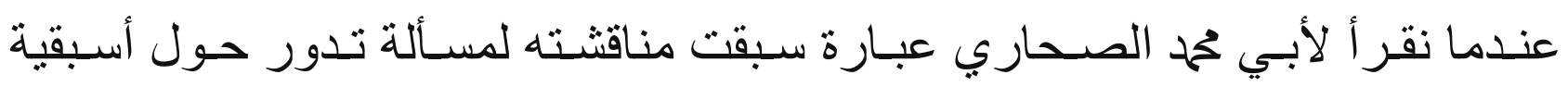

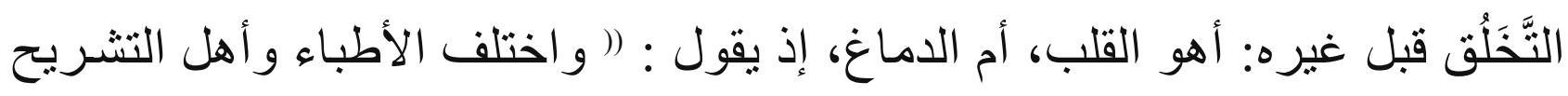
فميا يتكون قبل غيره ) (128). وكان التشـريح عماد عبد اللطيف البغدادي (ت 629هـ) في نقده للآر اء الخاصـة بالتشريح التي قال بها جالينوس ، ومن تبعة فيها من أطباء المسلمين ، فهو يرى أن أن مشـاهدة

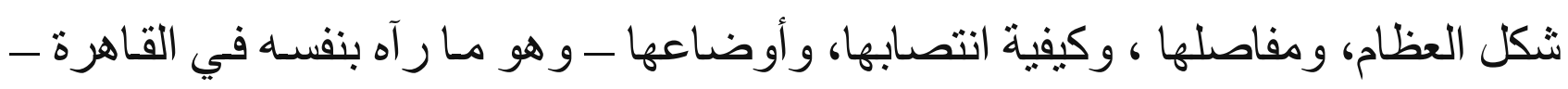

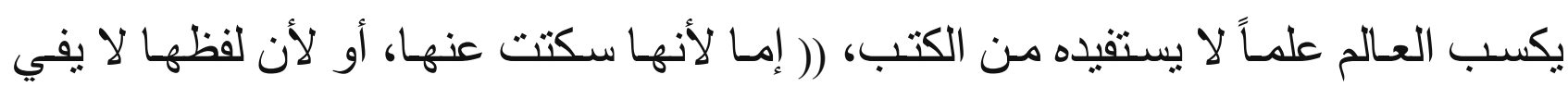

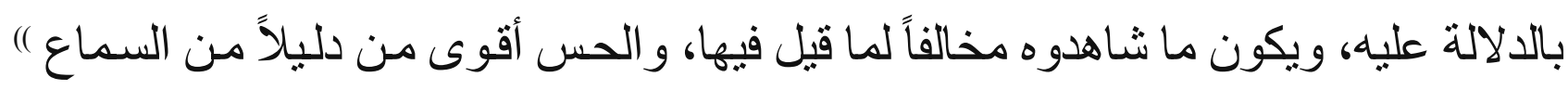

\section{ثُالثاً: تصنيف العلوم عند الصحاري}

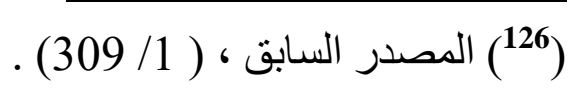

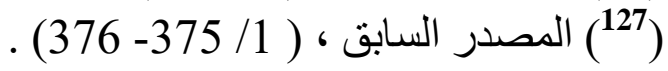

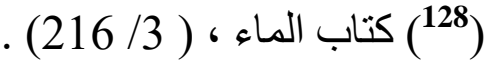
(129) عبد اللطيف البغدادي : الإفادة والاعتبار ، (ص 103). 
ونتجاوز عقدين من الزمان بعد ابن الهيثم لنتوقف عند الصحاري (ت 456هـ)

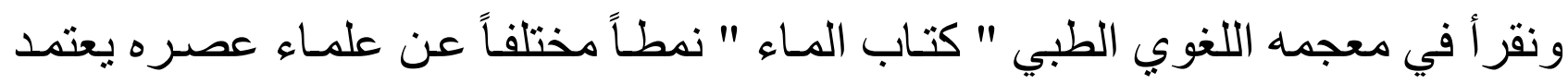

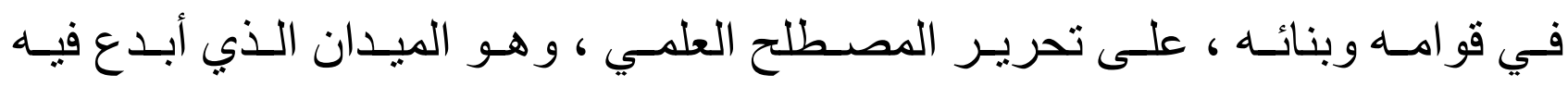

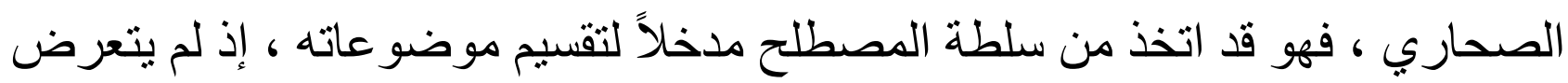

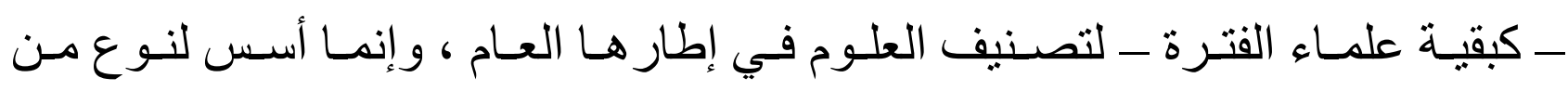

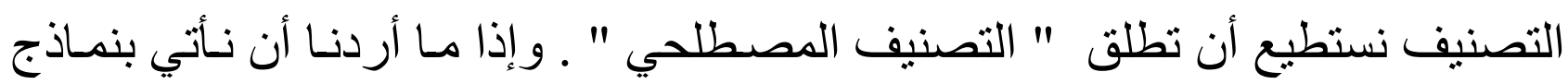

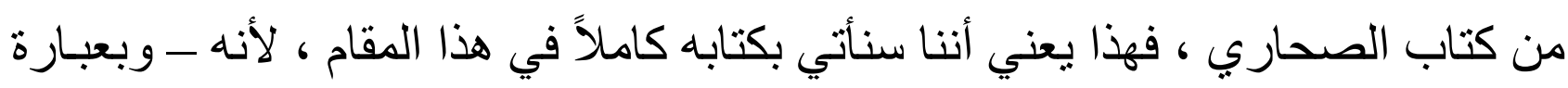
موجزة - من أوله إلى آخره يقوم على هذه النمط من التصنيف (130).

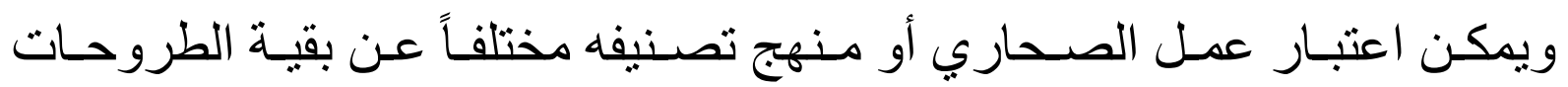

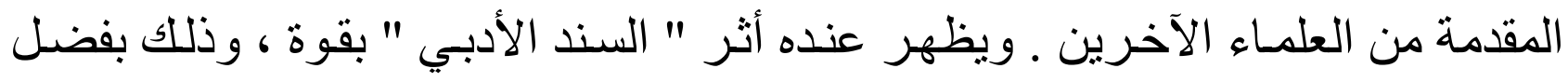

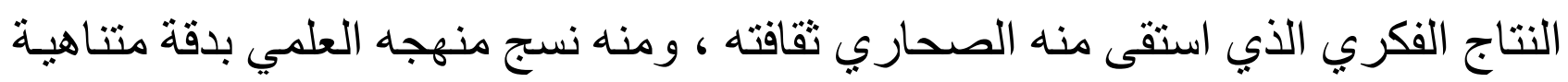

\section{رابعاً : تحرير المصطلح العلمي}

ولكن يظل أبو محمد الصحاري (ت456هـ) أكثر علماء فترة البحث اهتمامـاً بقضية

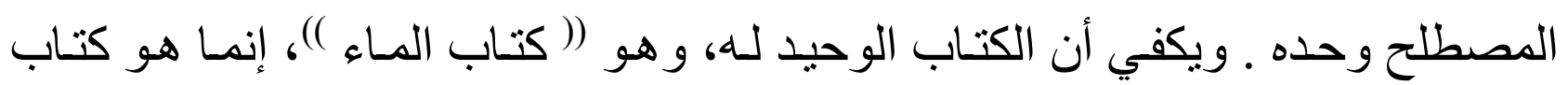

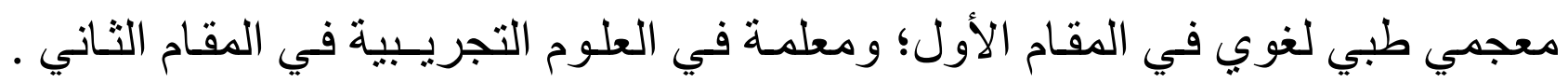

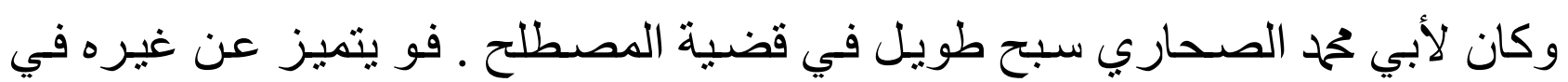

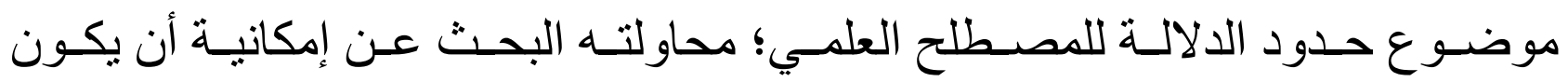

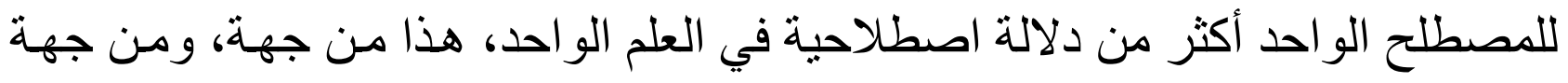
أخرى سعيه الحثيث إلى ضبط حد المصطلح إذا كان مفرداً أو لا يحمل إلا معنئً واحداً . هذا عمل الصحاري باختصار في معجمه . ومما يدل على التقنين في عمل الصحاري هذا؛ أن القارئ يلحظ أمر اً بـالغ الأهميـة في طريقة معالجة الصحاري لحد المصطلح العلمي، و هذه الطريقة تتمحور حول انتقال

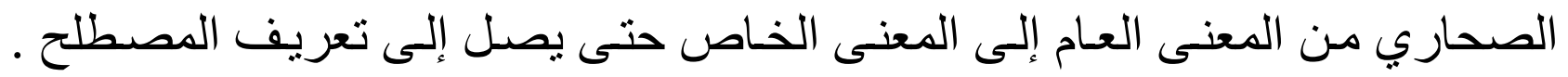

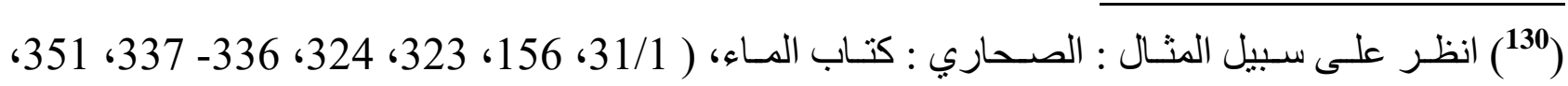

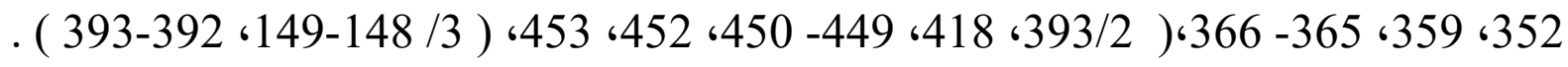




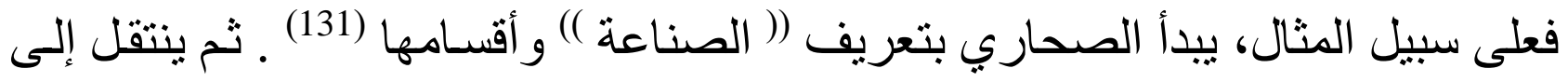

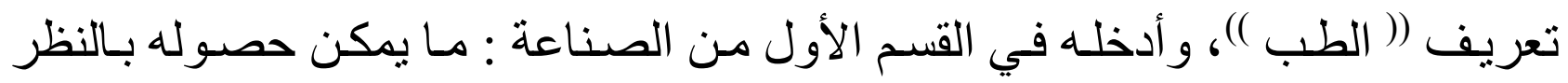

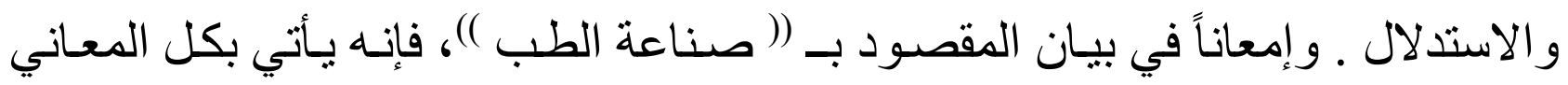

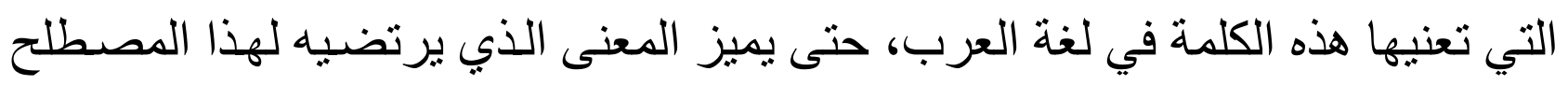

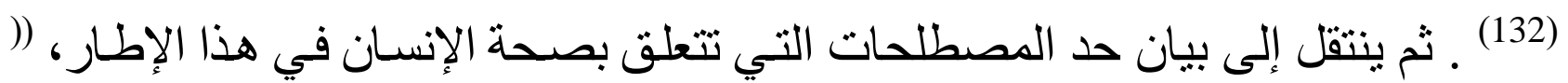

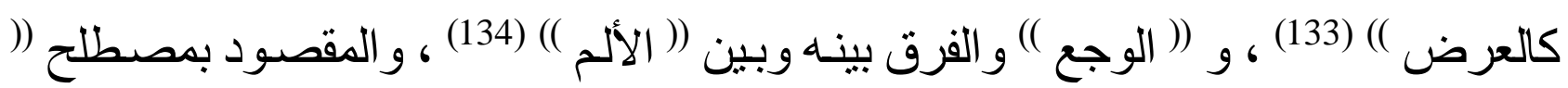
الناقة )) (135) . فالصحاري يدرك أهمية فهم حد هذه الهصطلحات لتعلق التشخيص السليم

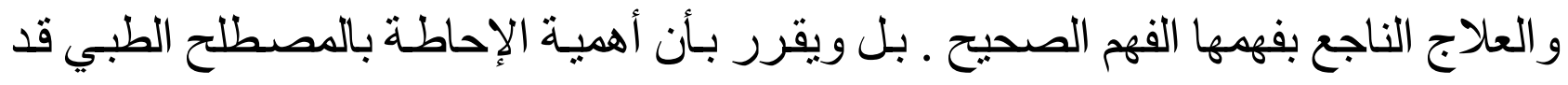

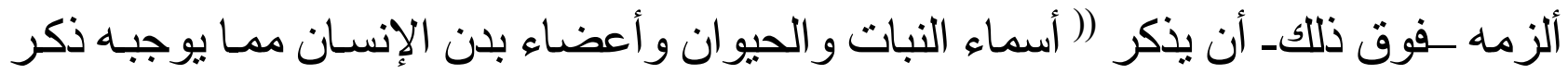

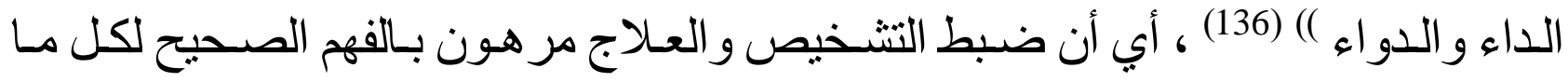

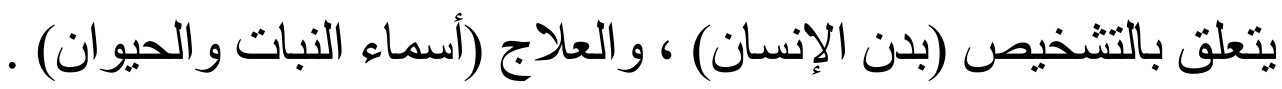

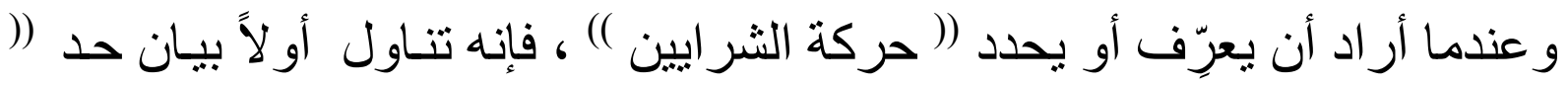

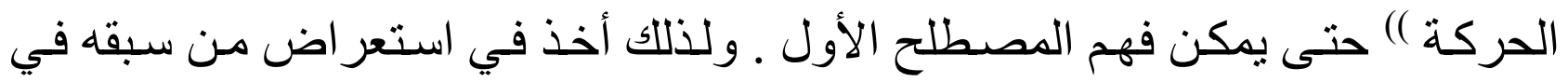
تعريفهم للحركة، واتفقوا على أنها : خروج الثـيء من القوة إلى الفعل على سبيل

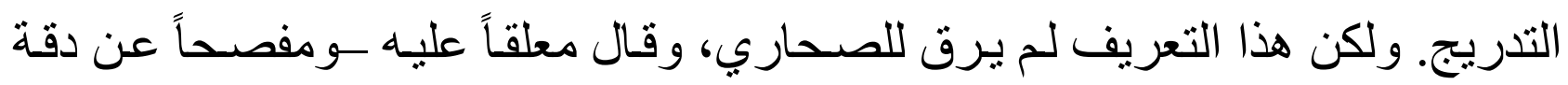

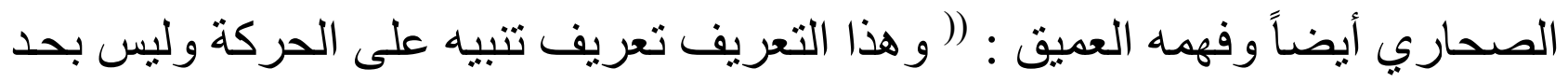
حقيقي )) (137) ثم يقول معقباً : (( والحد الصحيح لها هو : أنها كمال أول لما هو بالقوة ) )

و الحقيقة أن الصحاري عندما خـاض في مسألة (( حد الحركة )) إنما كان يتحدث

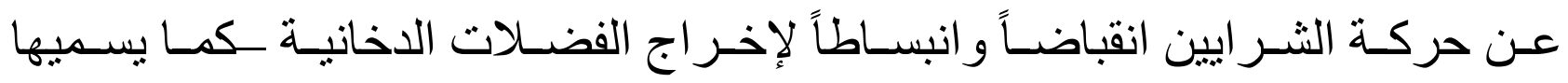


الصحاري- من الدم (139) . فكان ورود مصطلح (( الإخر اج ) ) مدعاة لتعريف (( الحركة ) المسبية لهذا الأمر أو المعنية بحدوثه .

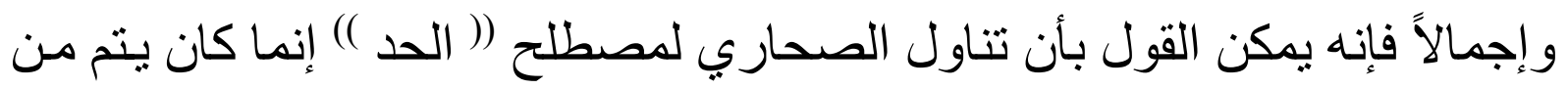

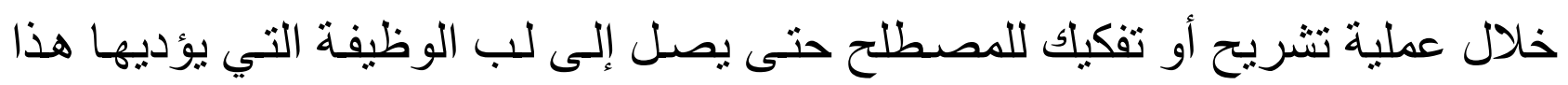
المصطلح معرفياً (140)

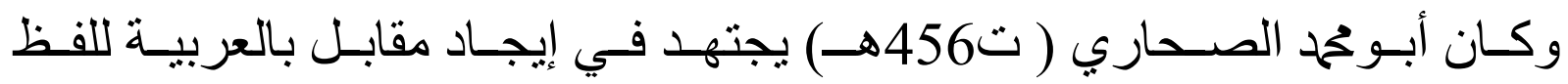

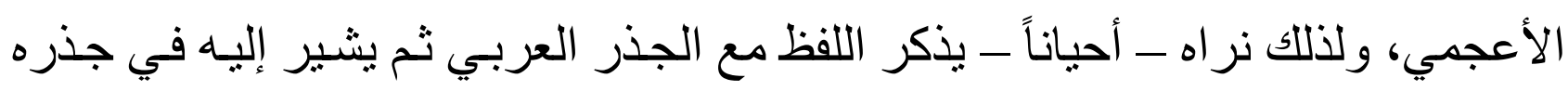

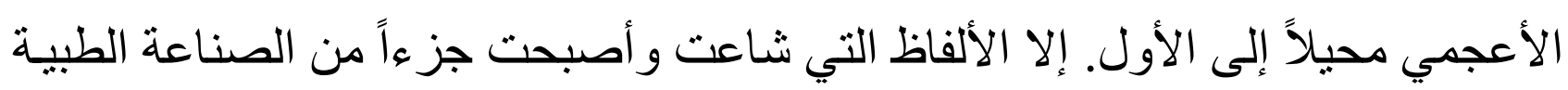

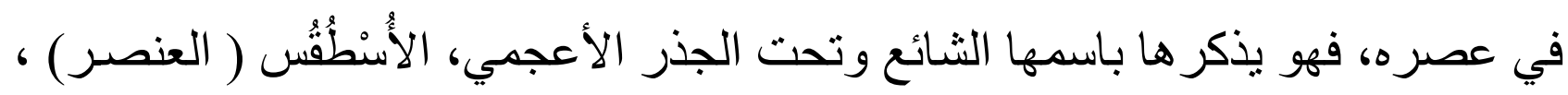

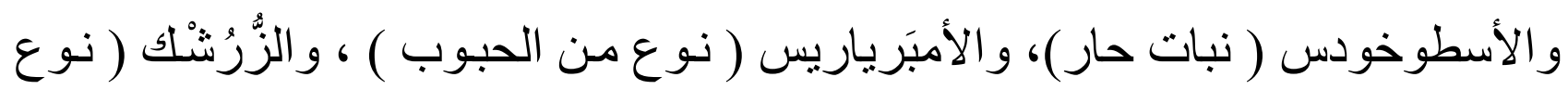

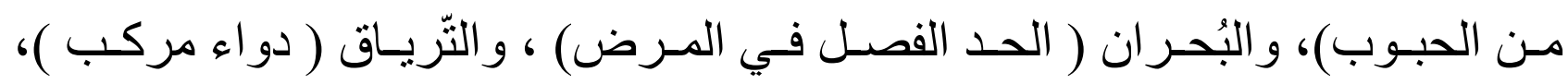
و اللَيُُرُ غُس ( مرض اض النسيان ) و غير ها من الدصطلحات التي يحفل بها معجمه (141) .

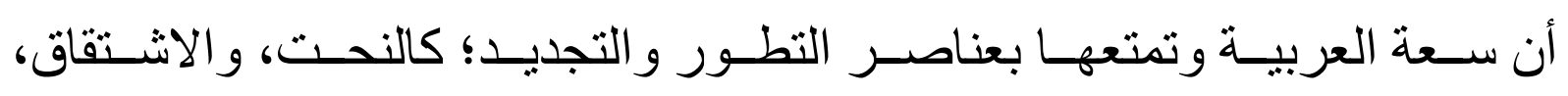

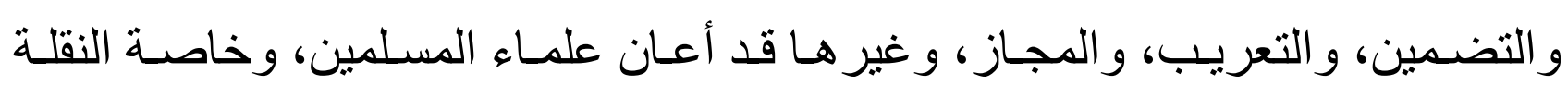
منهم، على وضع المصطلحات العلمية الطارئة .

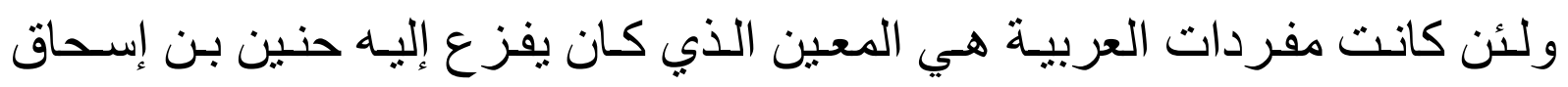

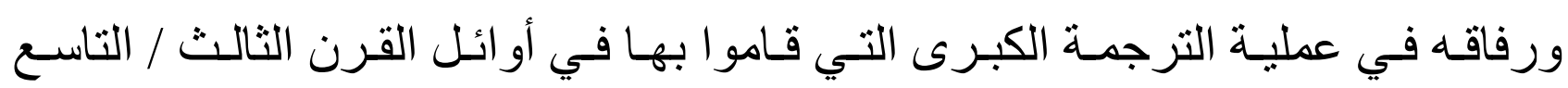

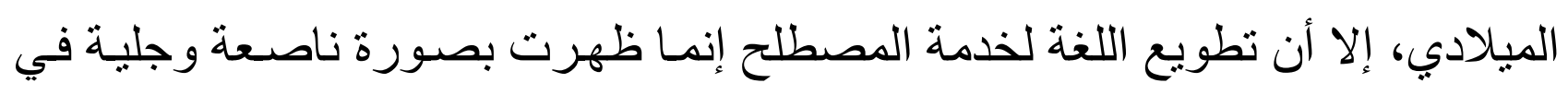

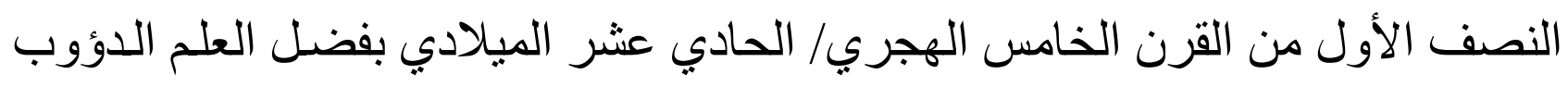

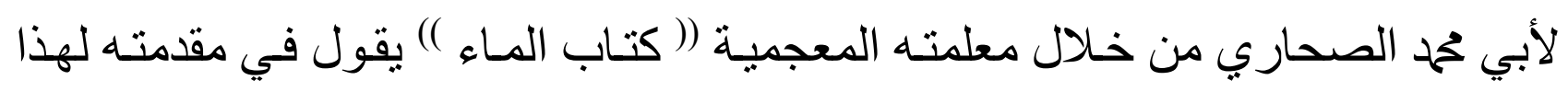

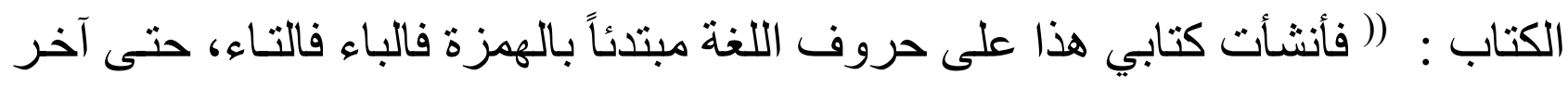
الحروف وهو الياء )( (142).

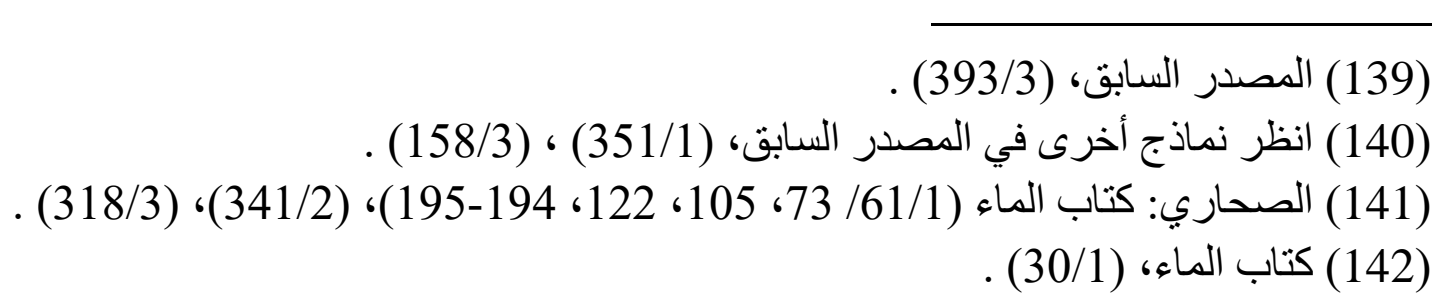


وكان الذي يدفعه بقوة نحو هذا العمل إيمانـه الكامل بأن اللغة العربية قادرة على

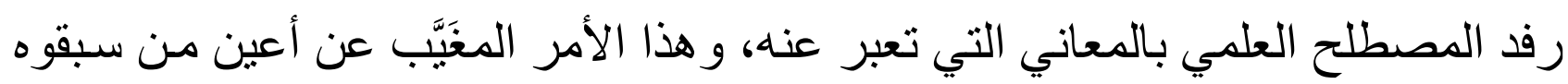

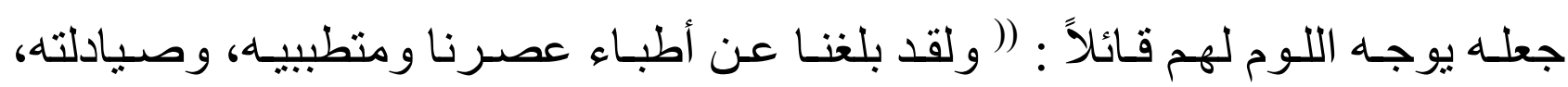

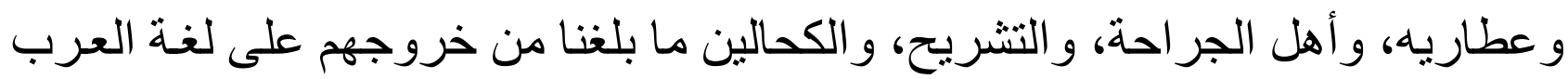
... فجهدت جهدي أن أعيد الأعجمي من لفظ الأطباء إلى رسوم لسان العرب )) (143).

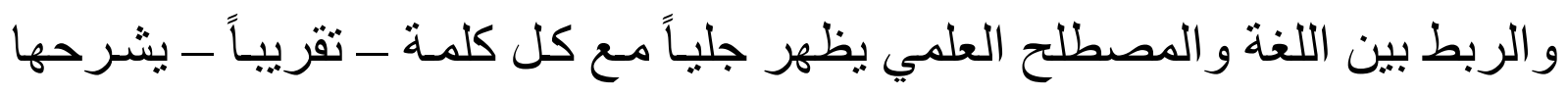

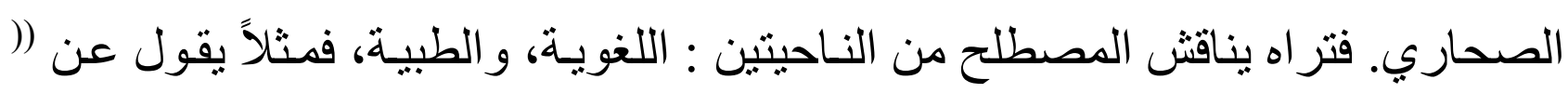
الصرع ) : الصر ع لغة : ... كذا، وطبا: ... كذا .

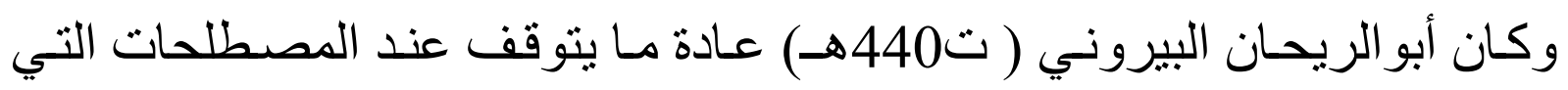

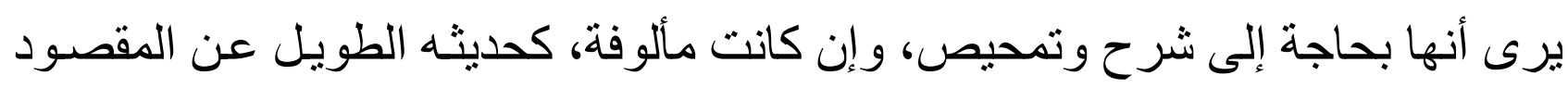

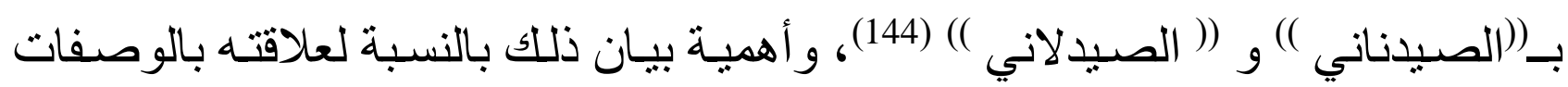

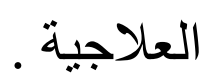
إلا أننـا نجد أبـامحد الصحاري ( ت456هـ) - المعاصـر للبيرونيـ أكثر دقـة من

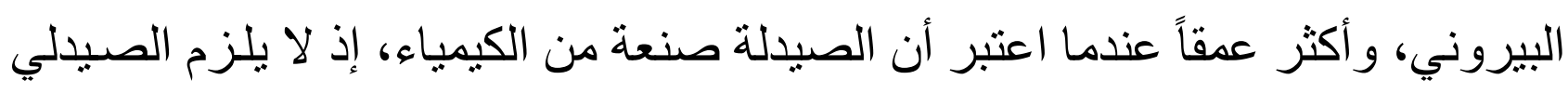

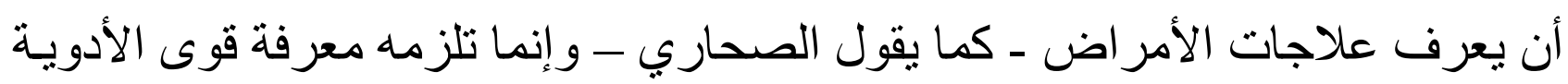

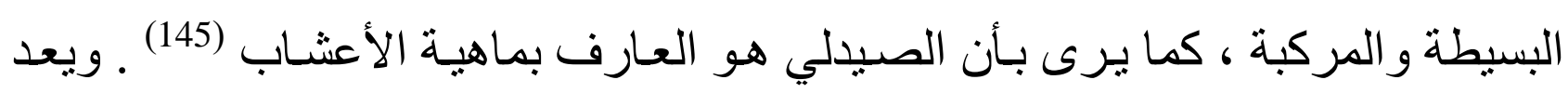

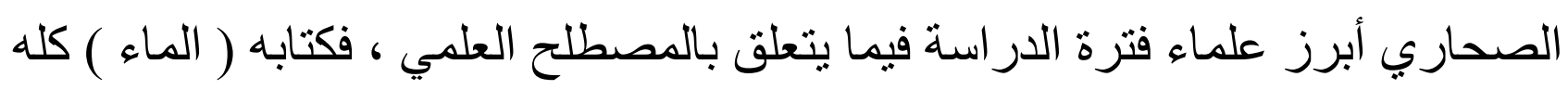

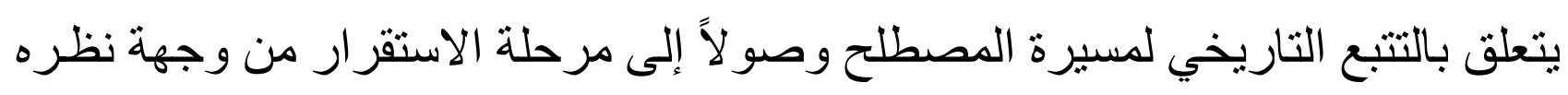

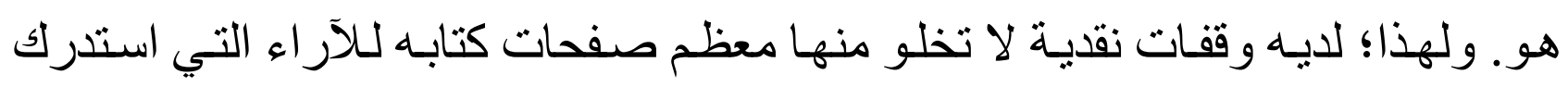

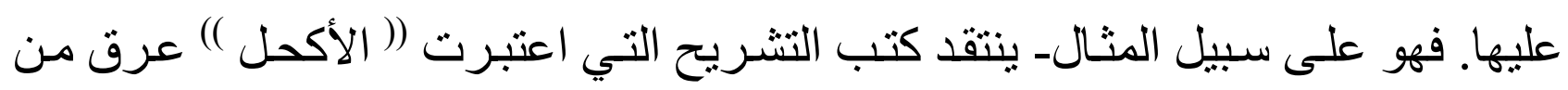

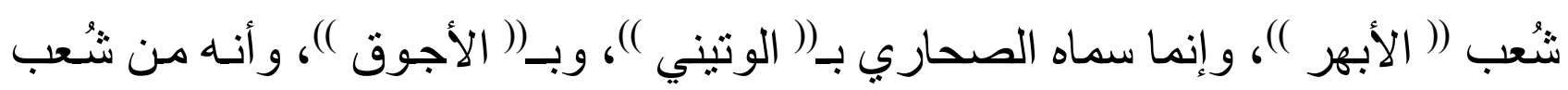
أحد عرقين يخرجان من الكبد (146).

(143) المصدر السابق، (31/1) .

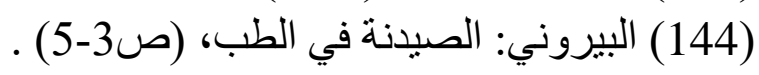

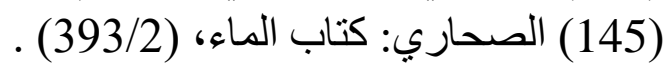
(146) المصدر السابق، (158/1) ـالب الماء/2) 
كما نرى الصحاري يوجه نقده لمن اتهم تعريفه (( للعضلة ) ) غير جامع ـإذ عرفها

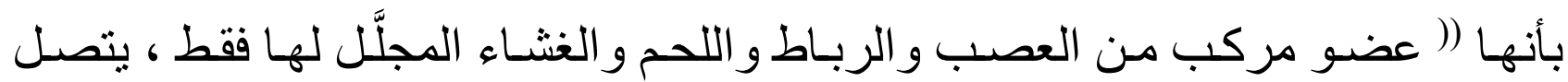
طر فها بالعضو المتحرك بالقوة المتحركة بالإر ادة بتوسط الانقبـاض و الانبسـاط )( (147)

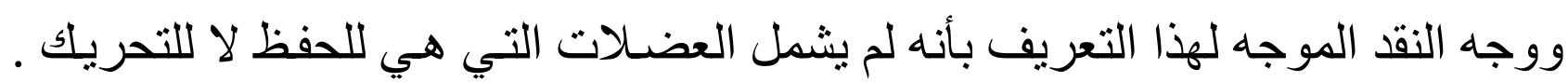

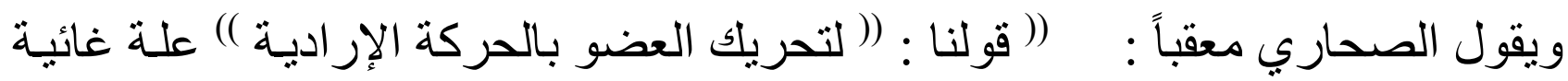

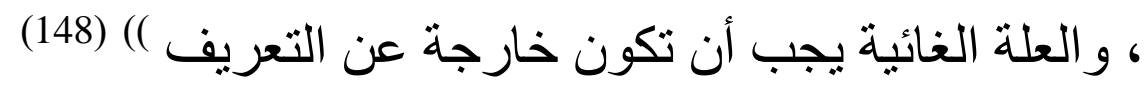
كما وجه نقده لاستخدام مصطلح (( معلول )) لمن أصابته علة أو مرضه، ونه وأن ذلك تو هم من الناس ؛ لأن استخدامها على الوجه الصحيح إنمـا يكون عند المتكلمين، وأهل الهـل العَروض (149) ـوكذللك أنكر على بعض الأطباء الذين حصـروا الحمبـات في ثلاثة

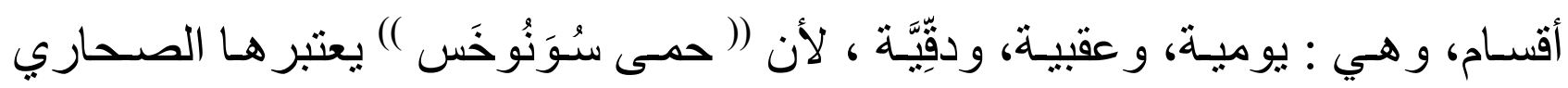
خارجة عن هذه الأقسام الثلاثة، ويقول في هذا الصدد : (( لا تتحصر أجناس الحميات في الأقسام الثثلاثة؛ فالو اجب في حصر ها أن يقال : الحمى لا تخلو إمـا أن تكون متعلقة . بها، فلا يخلو ... () (150) ثم يأخذ في بسط المسـألة حتى يضـع مصطلح (( الحمى ) ) في وضعه الصحيح، فيكون التشخيص ، وبالتالي العلاج صحيحين (151) خامساً : التجديد المعرفي و أقدم قبل ذلك من مقدماتهم مـا سيحتاج إلبـه فيمـا بعد )( (152) . إذ يـأتي البيروني بتلك المقدمات التي قالو ا بها، ثم يقدم هو بر هانهه على كل و احدة من تلك المقدمات،

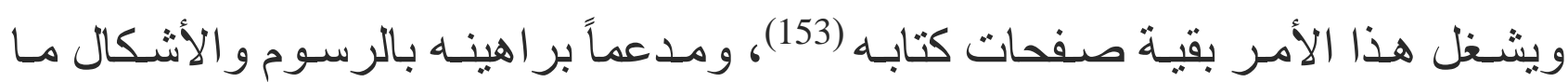
استطاع إلى ذلك سبيلا .

$$
\begin{aligned}
& \text { (147) المصدر السابق، (50/3) . } \\
& \text { (148) الدصدر السابق، (147) (50/3-51/3) . (50/3) . }
\end{aligned}
$$

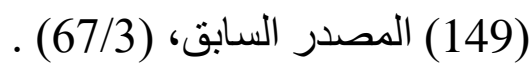

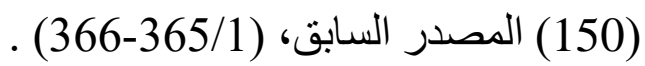

(151) انظر نماذج أخرى عند الصحاري في هذا الجانب أوردها في كتابه (( الماء )) (347/153، 359)،

. 163، 158-157/3)

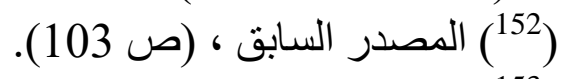

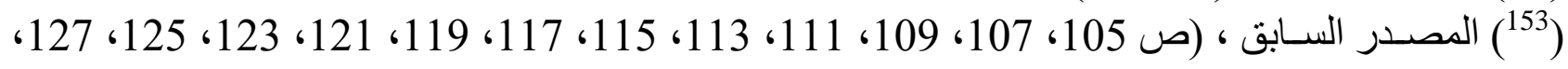
129، 131، 133، 135، 137)، و غير ها من الصفحات . 
وكان الدافع الذي أوعز إلى البيروني توجيه نقده لفئة من علماء عصره ركنوا للتقليد،

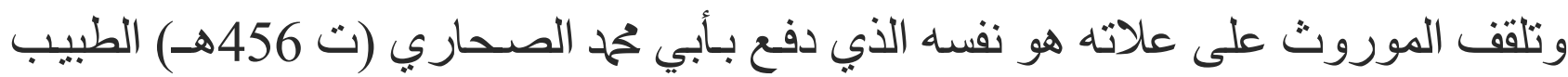

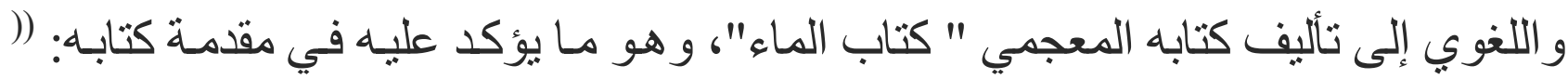

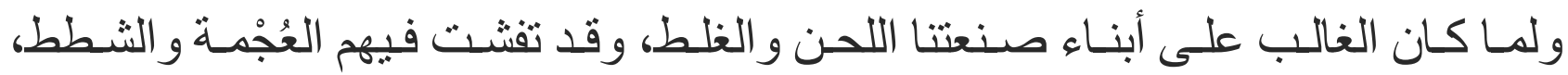

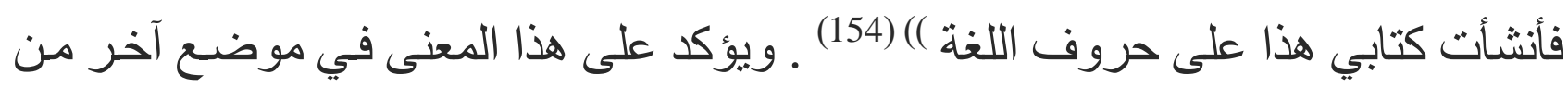

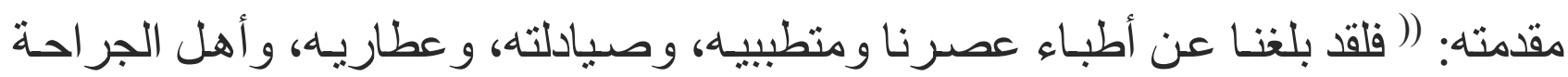

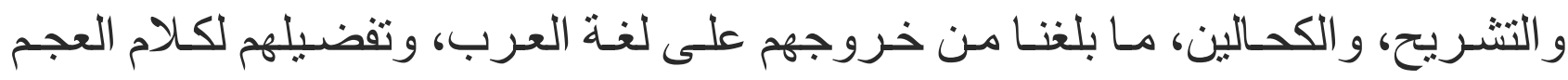

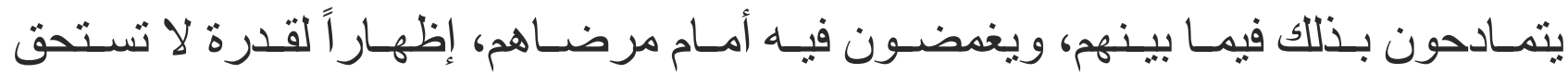

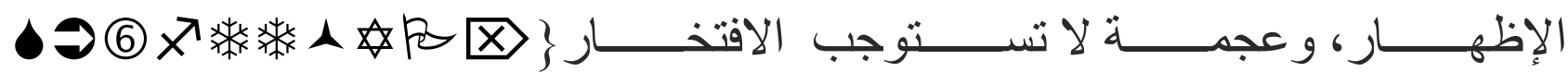

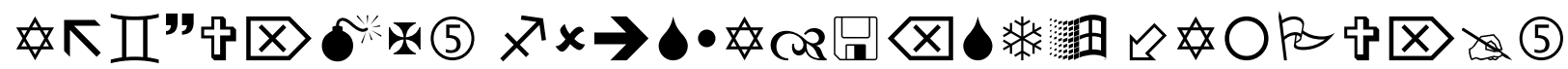

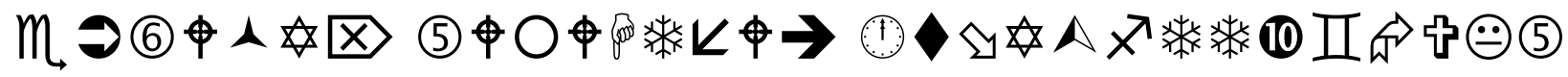

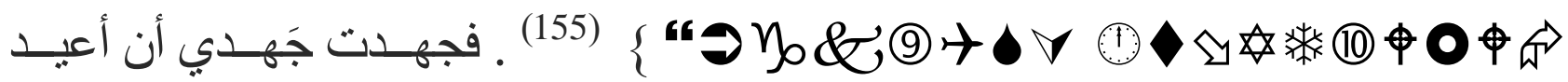
الأعجمي من لفظ الأطباء إلى رسوم لسان العرب )( (156). ويتضح مما سبق أن نقد الصحاري كان موجهاً - في المقام الأول - صوب قضئة الصنية تتعلق بالناحية اللغويـة في علم الطب، وتغلغل المصطلح الأجنبي واختلاطـه بالمفاهيم

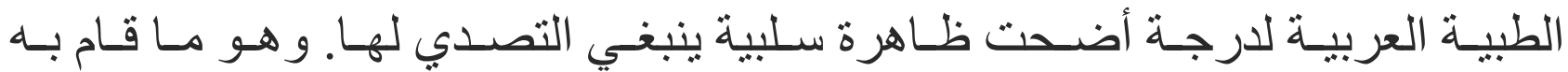

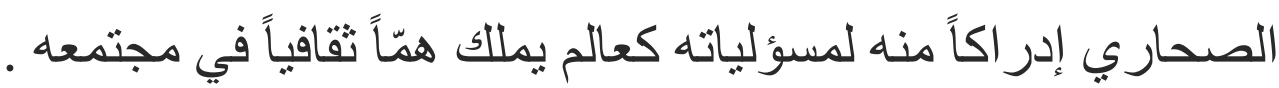

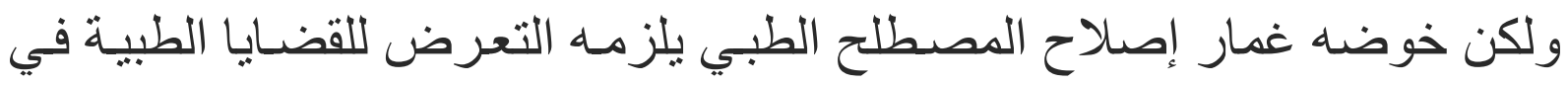

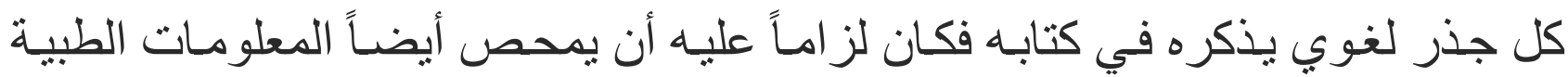

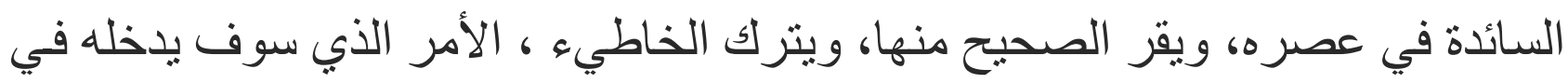

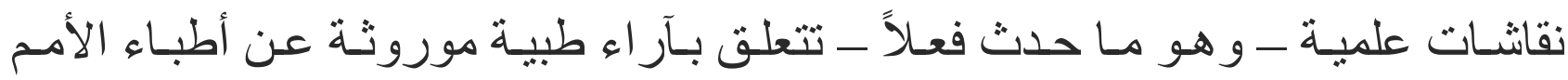

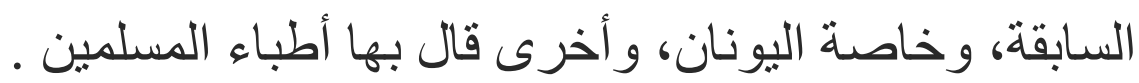
و هذا ما حدث فعلاً، إذ نلحظ الصحاري لا يكاد يمر على القضايا الطبية العالقة في

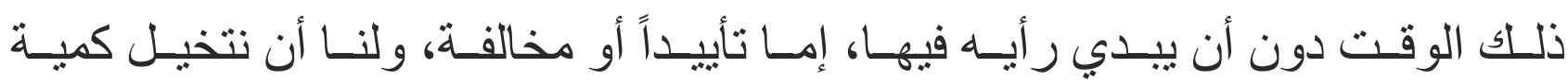


المصطلحات التي وردت في كتاب " الماء "، وبالتالي تقدير كمية النصوص النقديـة أو الاستدر اكية التي جاء بها الصحاري . وتحفظ الصحاري على الوضـع الطبي لم ينحصر على الجانب اللغوي فحسب،

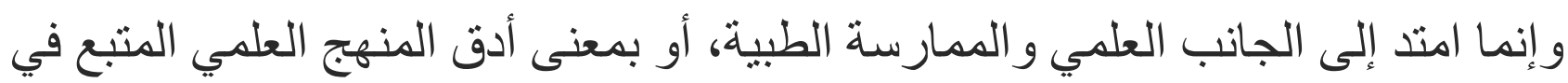

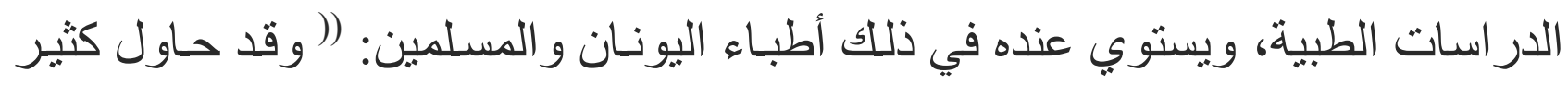

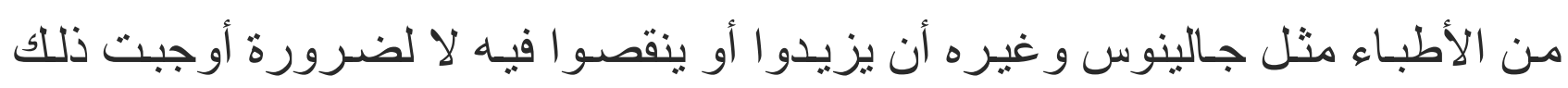

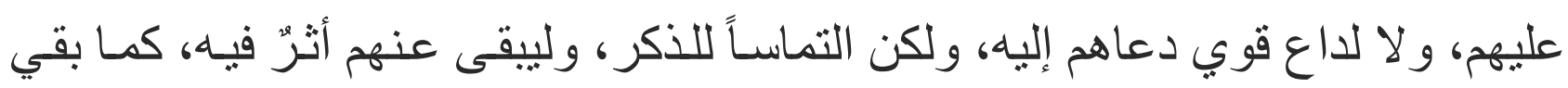

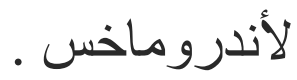

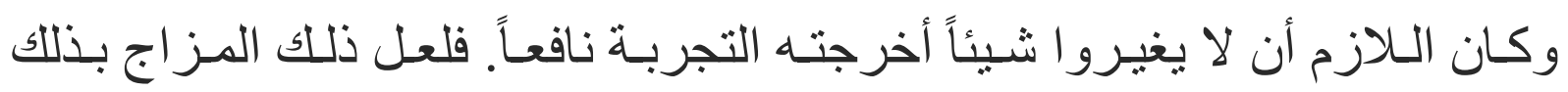

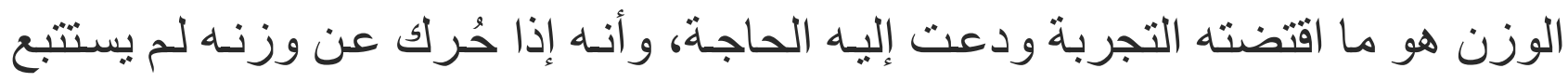

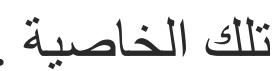
ثم إن ادعى ددع منهم أنه عارف بنسب تللك الأوزان، أو أنه تحقق كيفية حصول

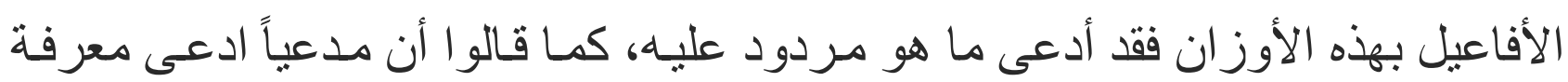
أوزان العناصر في الإنسان ) (157).

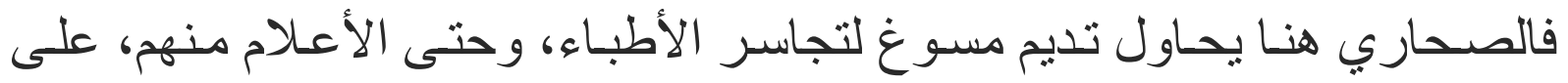

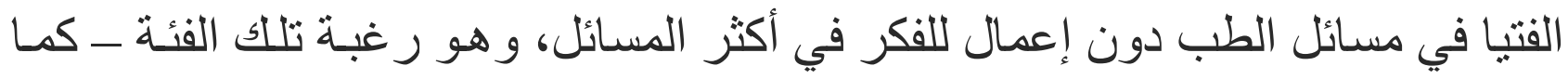

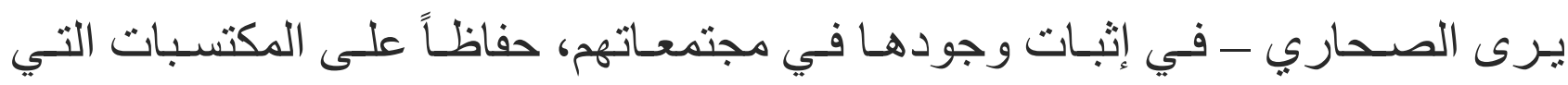
يحققونها من كونهم مسؤلون عن صحة أفر ادها .

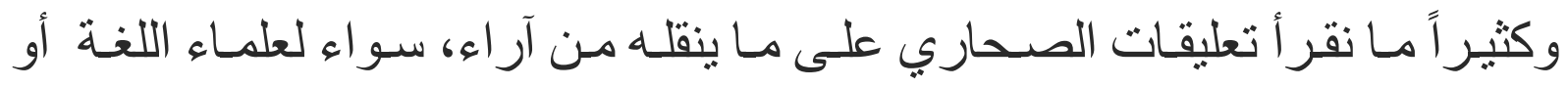
الأطباء، دون النظر إلى أسماء أصحابها، على نحو: ((وقول الجوهري: ...وهم، لأن...))

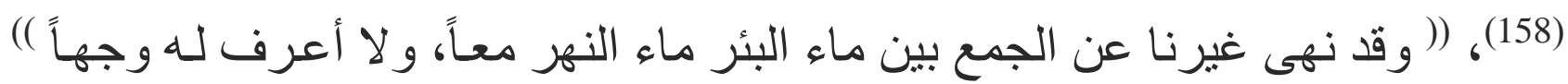

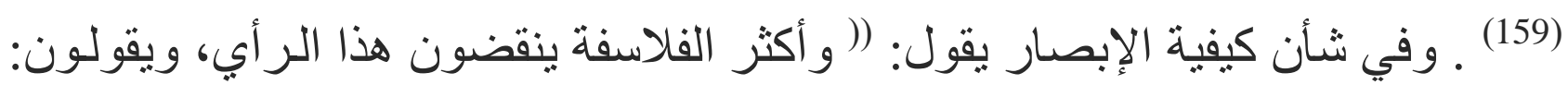
إن إدر الك النفس لهذه الأشياء إنما يكون بتوسط إدر الك القوى المخصوصة بها، ثم ينتقل

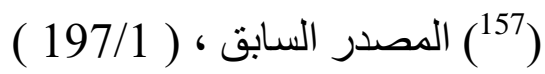

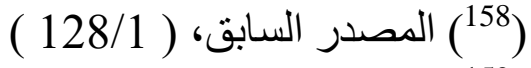

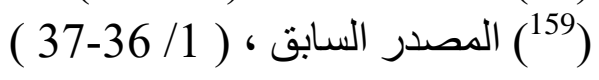


ذلك الإدر الك إلى النفس. والحق إن الأمـر كذلك )) (160) ـ وفي شـأن أنواع الحميـات،

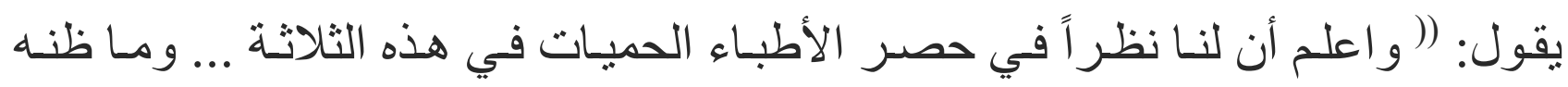

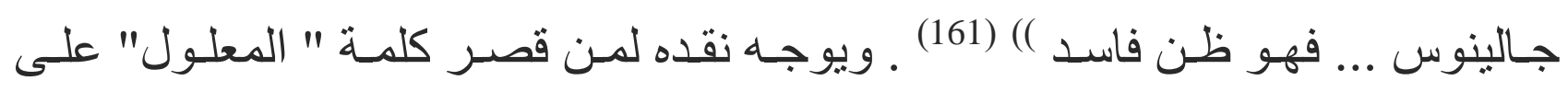

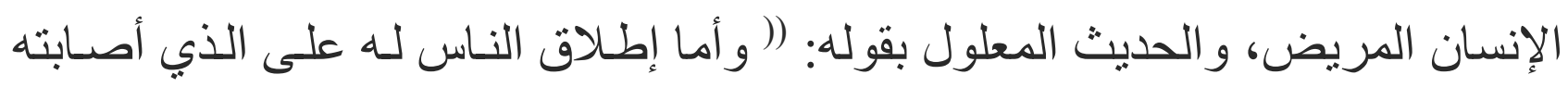
العِلة، أو الحديث المعلوم، فهو و هم. ويقال لذلك " مُعَّل (( من أعله الله ومعلل )) (162) .

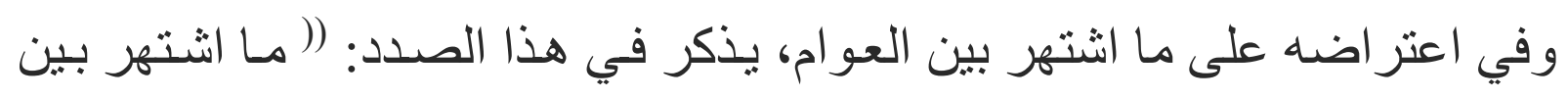

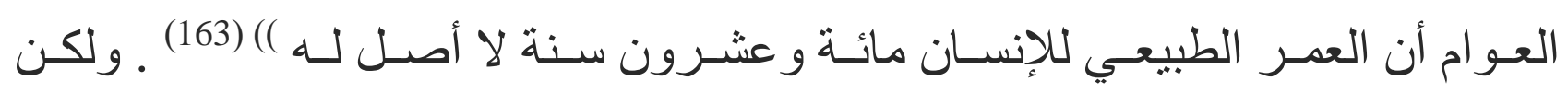

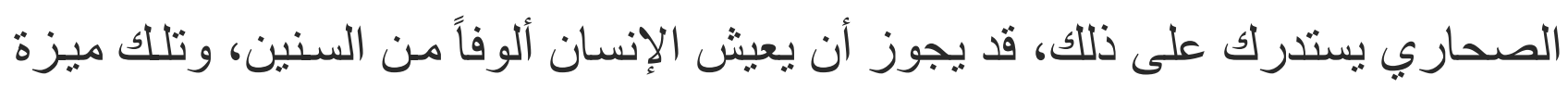

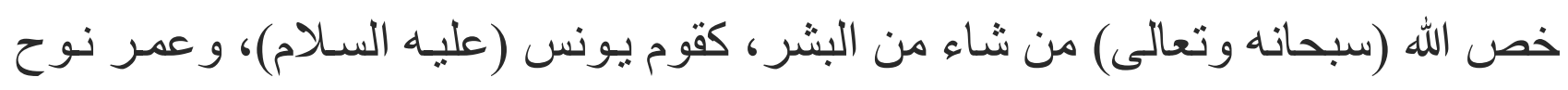

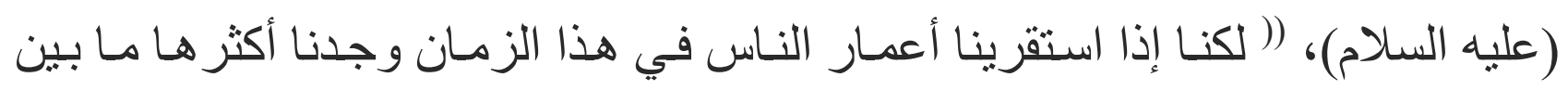

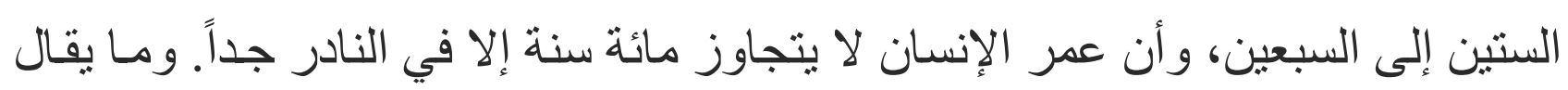

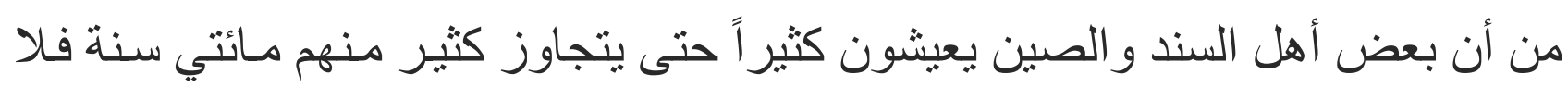
صحة له () (164) لهن

وفي موضع آخر يبدي الصحاري استغر ابه الثديد مما ذكره البيروني من أن نبات

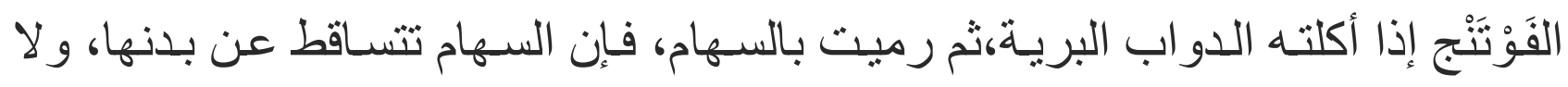
تضر ها بشيء، ووصف ذللك بأنه (( من الأعاجيب التي لم نقف عليها )) (165) .

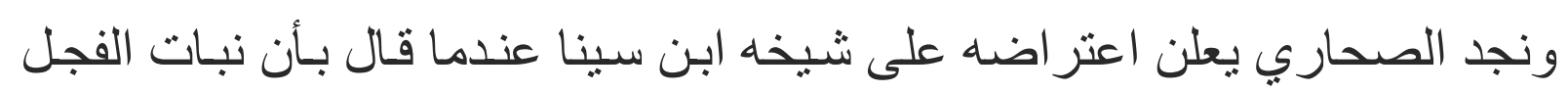

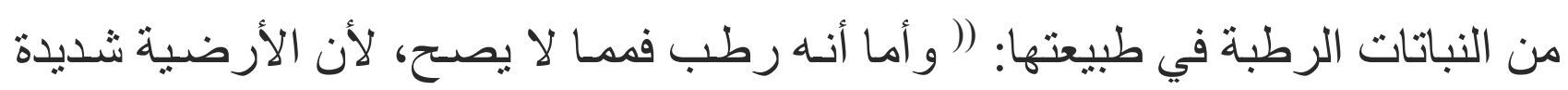

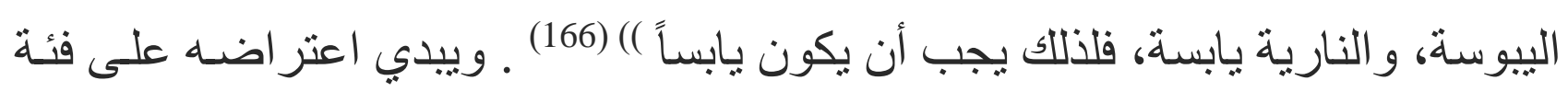
من الأطباء ظنت أن المر اد بمقولة " الصحة تحفظ بالمثل " أي الصحة التامة: (( و عندنا

(160) (131/1) المصدر السابق، (165/1)

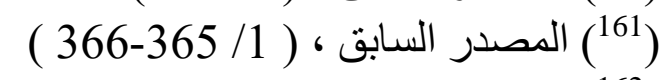

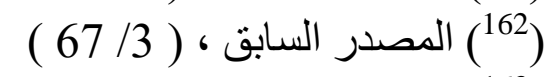

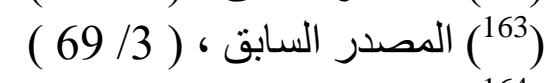
(64) الدصدر السابق ، (69/3 (69/3) )

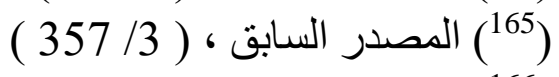
(166) (164/3 الصصدر السابق ، (167/3) ( 
أن هذا القول ليس بسديد ... فالمر اد بقولهم " الصحة تحفظ بالمثل "، أن ذلك الصحيح هو الذي تقاربت فيه كيفيات العناصر. وهذا هو المعتدل الطبي )( (167)

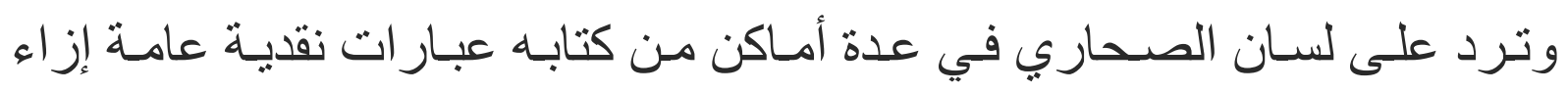

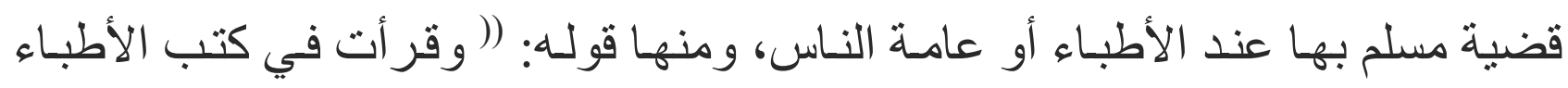

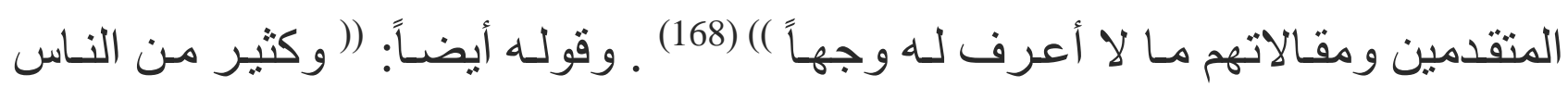
يقولون أنه ... وليس الأمر كذلك )) (169) ، وكذلك: ((وقد رأيت من إهمال أهل عصرنا

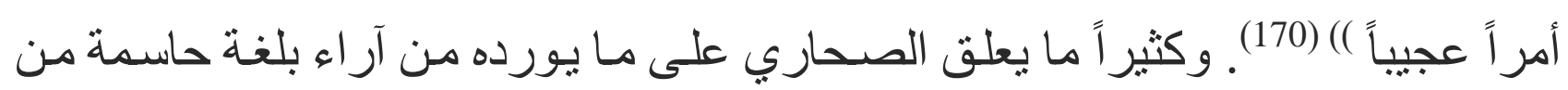

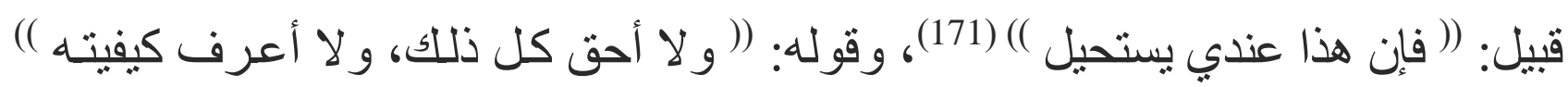

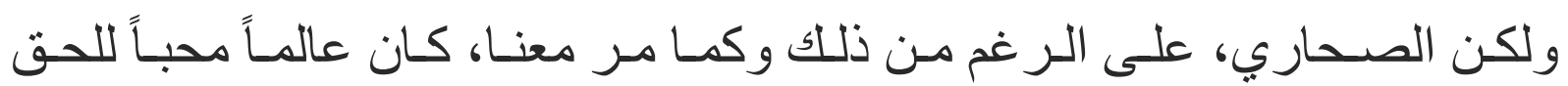

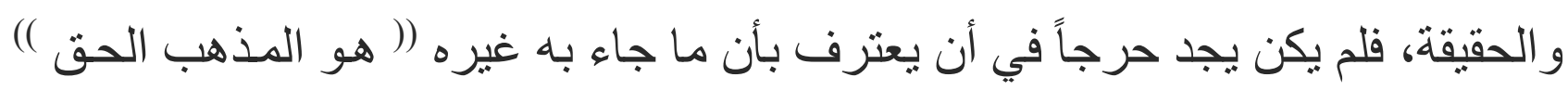

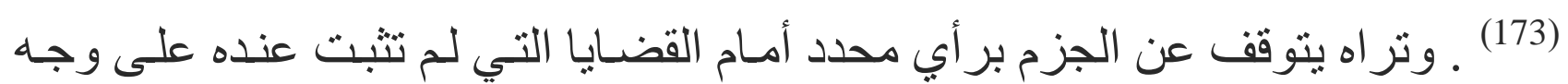

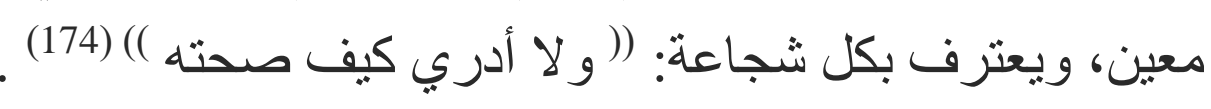

\section{سابعاً : الإيمان بسيرورة العلوم}

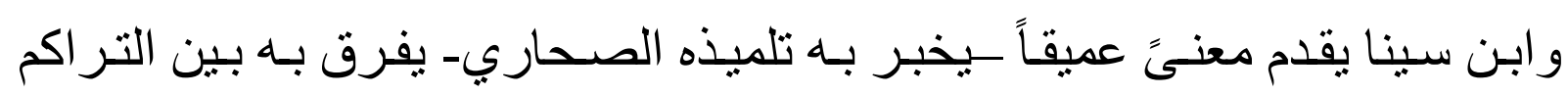

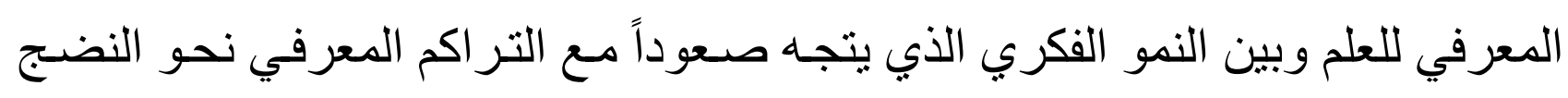

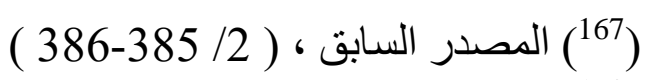

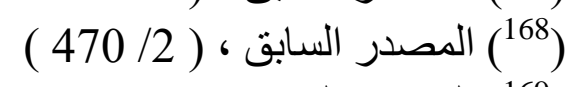

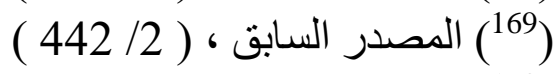

(170) (المصدر السابق ، ( (411/2 ) (470/2 )

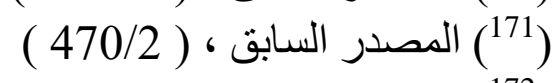

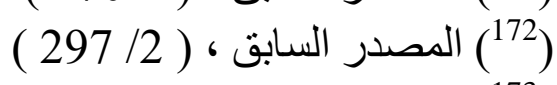

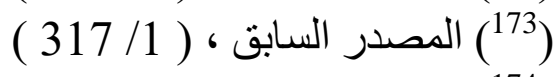

(174) المصدر السابق ، (1728 (128) ) 
العلمي، فنجده يتحدث عن نشأته العلمية ثم وصوله إلى مرحلة يرى بأنها جعلته يستثر

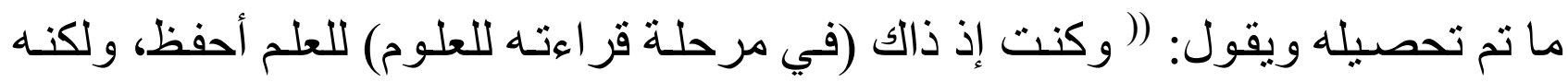

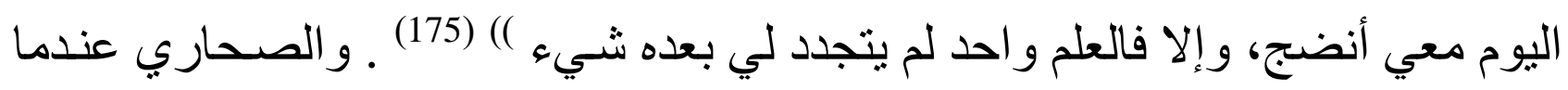

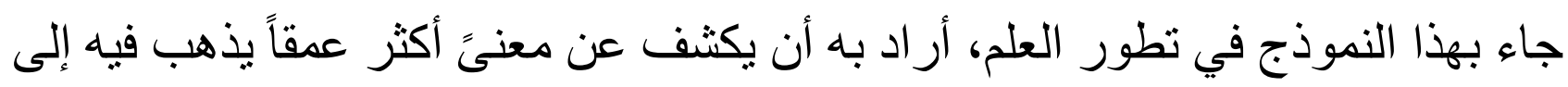

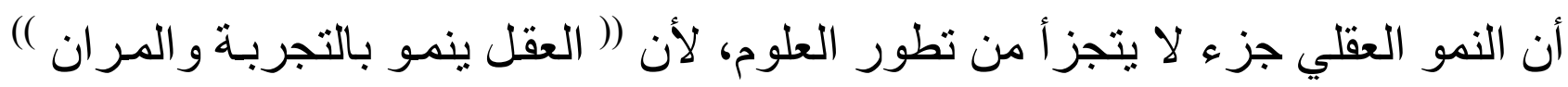

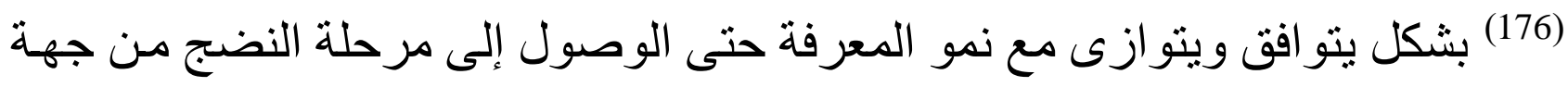

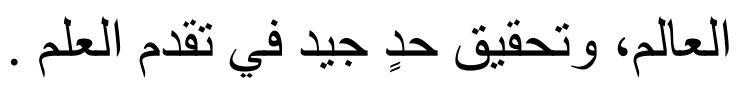

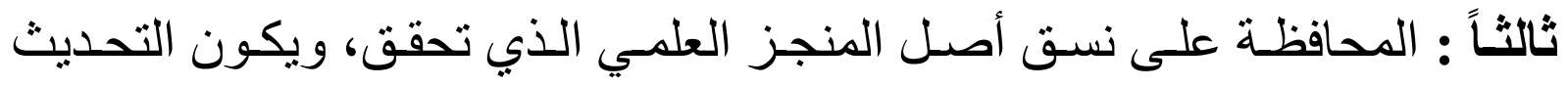

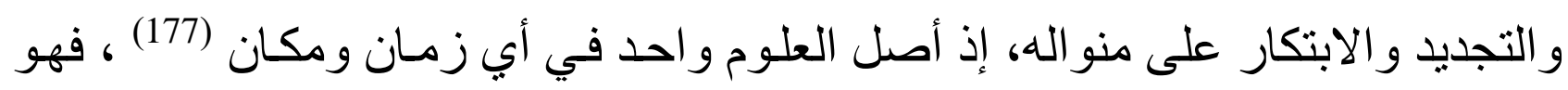

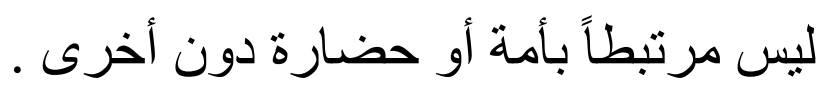

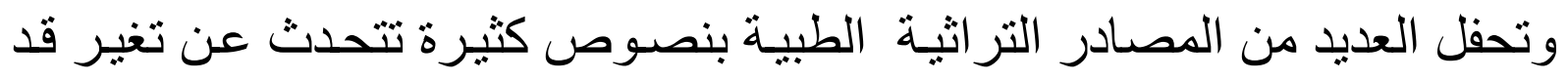

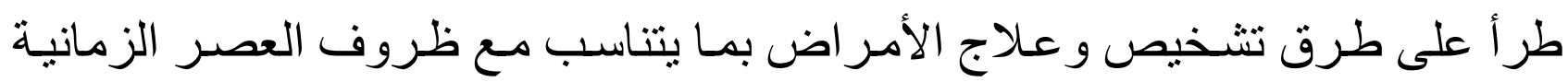

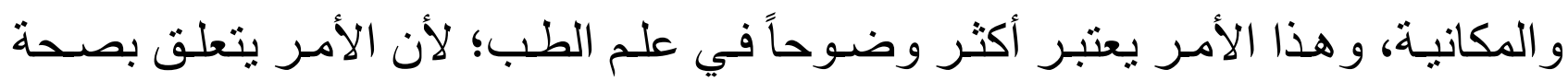

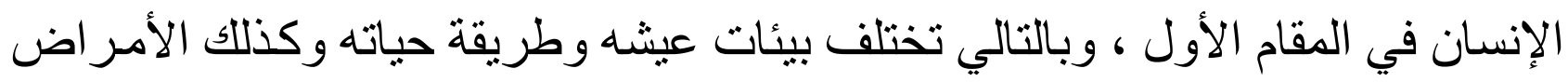

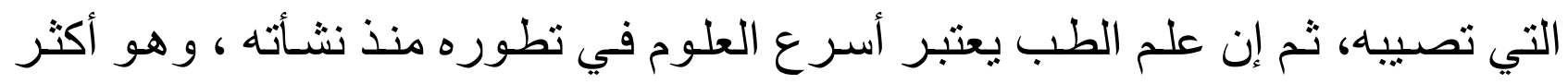

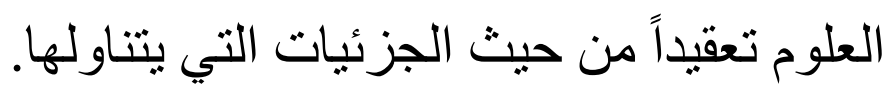
أما بقية العلوم فإن رياح التغيير قد أصسابتها، ولكن ذلك التهيت التغيير كان في الوسـائل

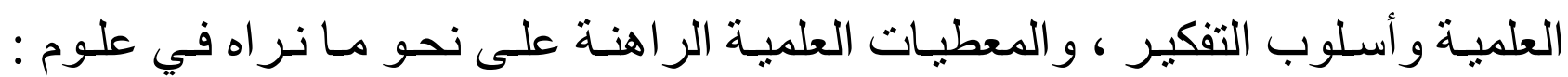

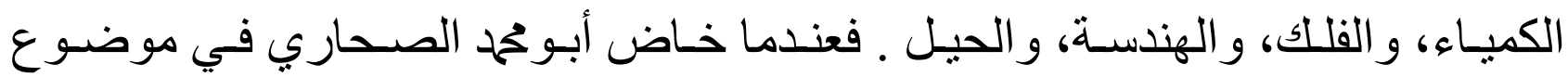

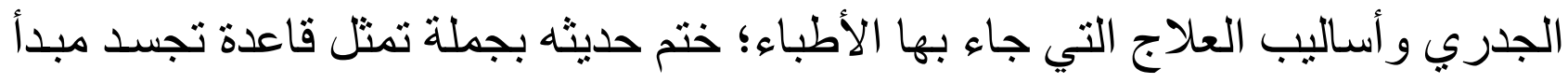

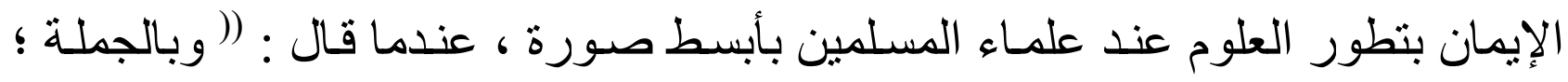
فعلاجه ( يقصد الجدري ) يرجع إلى اجتهاد الطبيب بحسب ما بر الاهبط في وقته )) (178)

$$
\begin{aligned}
& \text { (175) الصحاري : كتاب الماء ، (61/3) (61/3) . } \\
& \text { (176) المصدر السابق ، (61/3) . (175) ل }
\end{aligned}
$$

(177) يقول الصحاري في هذا الصدد : (( واعلم أن في المركبات أدوية هي عدة وأصل، إذا حذفت بطلت

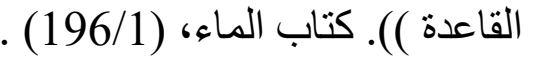

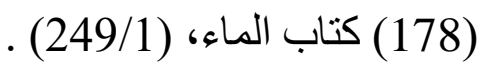




\section{سابعاً : ضوابط المعرفة}

لم يجد علماء المسلمين صسعوبة كبيرة في بنـاء المنهج العلمي وتطويره وتطبيقه و الالتز ام به في بحوثهم و أعمالهم العلمية لأن مبادئ وقو اعد و أخلاقيات هذا المنهج في

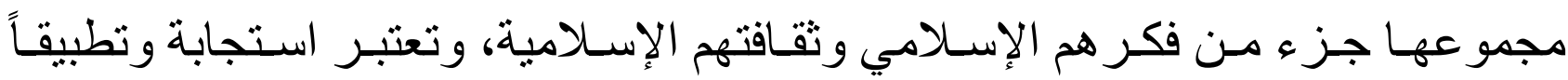

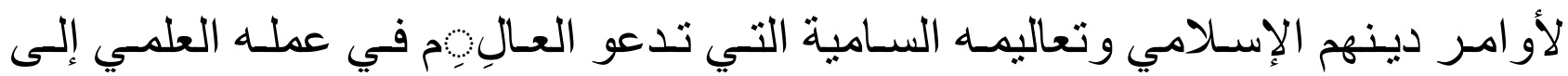

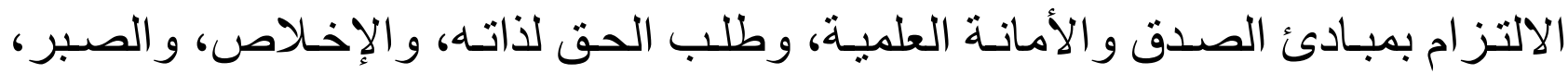
و الوضوح، و الدقة، و الموضو عية ـ و التي تدعو في الوقت نفسه إلى تجنب ما يقابل هذه المبادئ من المعاني السلبية . ولقد نـادى علمـاء المسـلمين (179) بكثيـر مـن مبـادئ و أخلاقيـات البحـث العلمـي وطبقو ها علمياً في أبحاثهم العلمية، وهي بالتالي تعبر عن أخلاقيات النقد لديهم ـ ومبدأ الخلقـة في النقد مرجعـه فهمهم الو اضـح لتطـور العلـوم، الأكـر الذي جعلهم منصففين و متحفظين في نقدهم ـ وبالتالي يصبح النقد لديهم بنـاءً لهرم المعرفة، وليس انتقاصـا أو نقداً لمجرد النقد، و هو ما استو عبه البيروني عندما عزم على تأليف كتابه (الصبينة في الطب) ، و هو القائل : (( فقد كنت طالعت لأبي بكر الرازي في الصيدنة والأبدال لم أفز

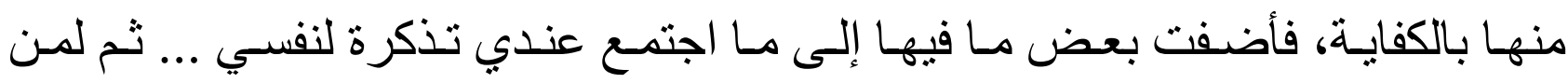
جانسني بحب الفضيلة واقتفائها بشرط المكافئات في تصحيح ما أمكن تصحيحه من زلة أو سهو أو غفلة )) (180) ـ ويرسخ البيروني الأسس الخلقية في النقد في كتاب آخر لله مما

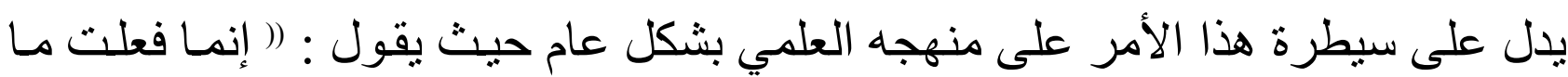
هو و اجب على كل إنسـان أن يعمله في صـناعته مـن تقبـل اجتهاد من تقدمـه بالمئة، وتصحيح خلل إن عثر عليه بلا حشمة، وتخليد مـا يلوح لـه فيها تذكرة لمن تأخر عنهـ

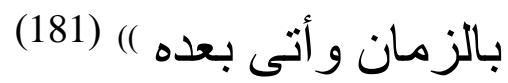

ونلحظ في المنهج النقدي عند المسلمين صورة جميلة للنزاهة ونكران الذات و الأنا لديهم في أحيان كثيرة حتى أصبح هذا الجانب الأخلاقي خصيصة من خصائص النقد .

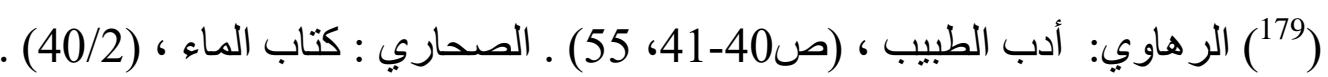

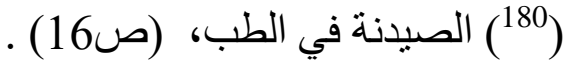

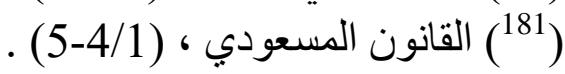




\section{أولاً : الضابط الأخلاقي}

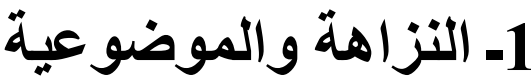

ومما يدل على موضو عية وحيادية علماء المسلمين ونز اهتهم في اتجاههم النقدي

اعتر افهم بـالآخر ، وحرصهم الثنديد على عرض وجهة النظر المقابلة في دراسـاتهم النقديـة، حتى يكون القـارئ على بينـة مـن فحوى الر أي المنقود، مـع الإقرار بفضلـل صـاحبه، فصرحوا بعمق العلم اليونـاني، وجهود أرسطو في نأسيس علوم المنطق، و الطبيعيات و الإلهيات على منهج يقوم على الجمع بين الحس و العقل (182) ـ و الحياد قد

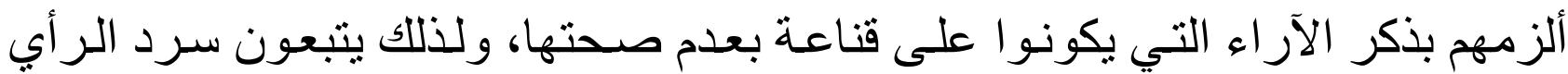

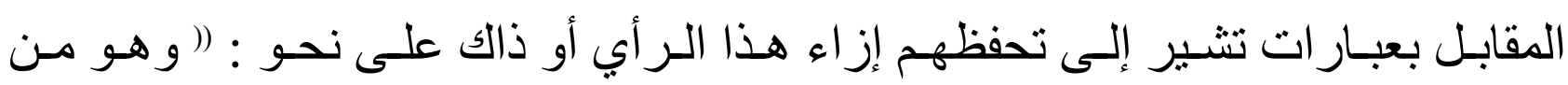
الأعاجيب التي لم نقف عليها ) (183)

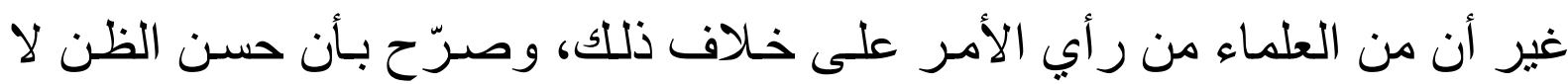

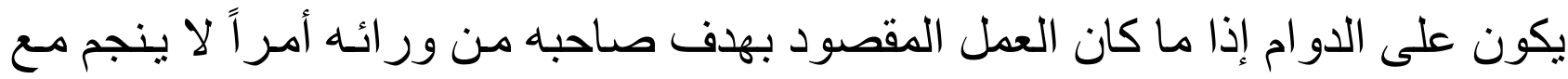
أخلاقيات العلم، فعلى الرغم من احترام الصحاري لعلماء اليونـان؛ إلا أن ذلك لم يحول

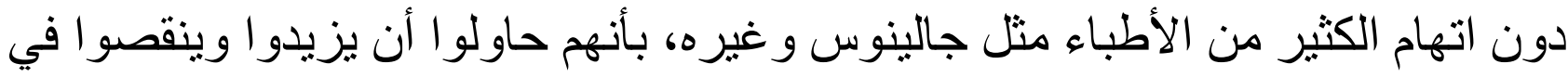

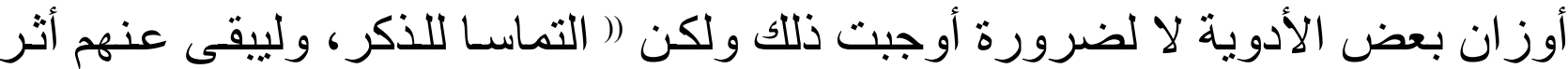
فيه، كما بقي لأندروماخس ) (184) كما كان التأدب في رفض الآر اء العلميـة الدخالفة إحدى مميزات الضـابط الخلقي السائد في منهج علماء المسلمين النقدي "( و الحق أنه ليس كذللك...وقد غلط فيه جمع كثير الأبر من فضلاء الأطباء )" (185) ، ((و عندنا أن هذا القول ليس بسديد )) (186)

$$
\begin{aligned}
& \text { (182) ابن أبي أصيبعة: عيون الأنباء، (ص552) (357) . }
\end{aligned}
$$

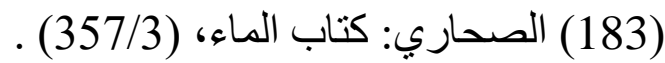

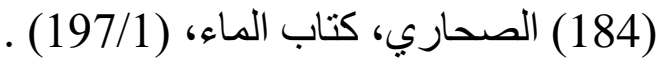

$$
\begin{aligned}
& \text { (185) الصحاري: كتاب الماء، (411/2) ـ و انظر : الكثكري: الكناش في الطب، (صناء) (214) . } \\
& \text { (186) الصحاري: كتاب الماء، (185/2) (485) . }
\end{aligned}
$$


وفرض تمسـك علمـاء المسـلمين بمبدأ نصـرة الحق عليهم قدر ا مـن المسؤولية التاريخية في إثبات كل ما يتعلق بكل قضية علمية يتناولونها بالدرس و النقد، الأمر الذي الذي العزي جعلهم يحرصون كل الحرص على استعر اض الآر اء المختلفة حيال قضية معينة كما

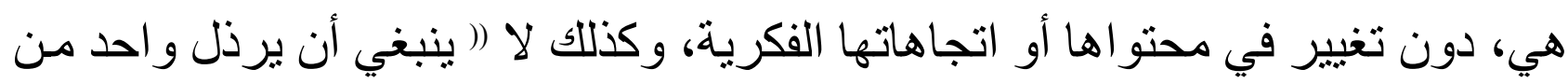

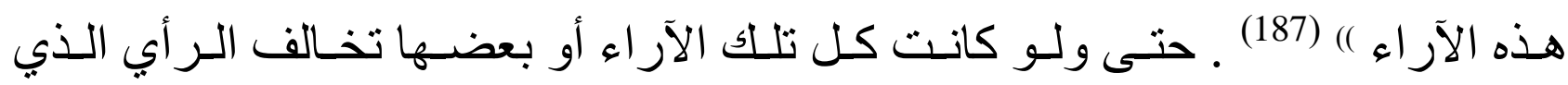

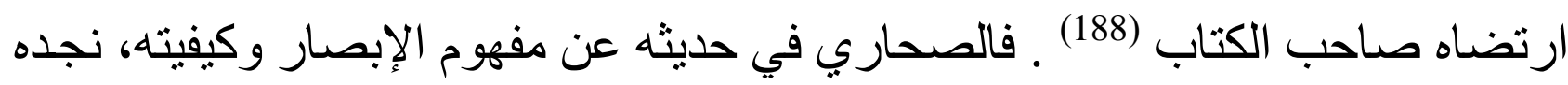

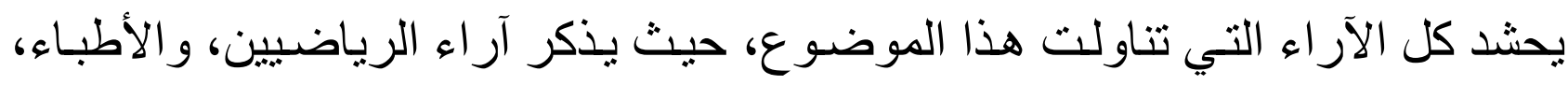

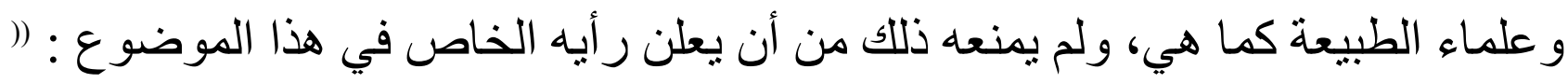

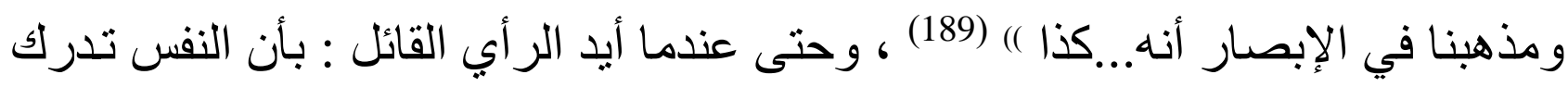

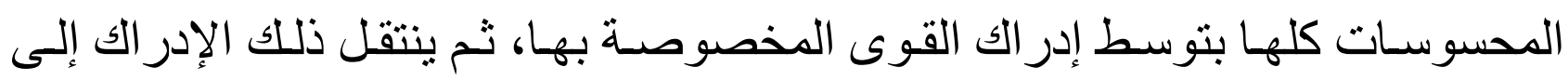

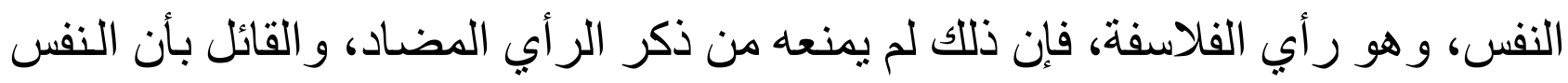

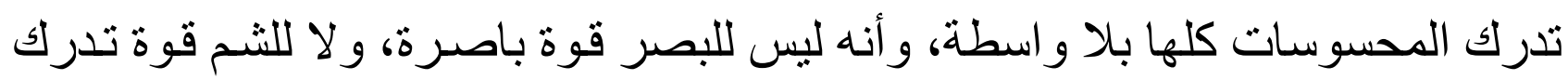

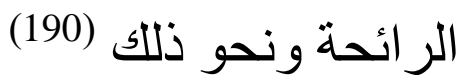

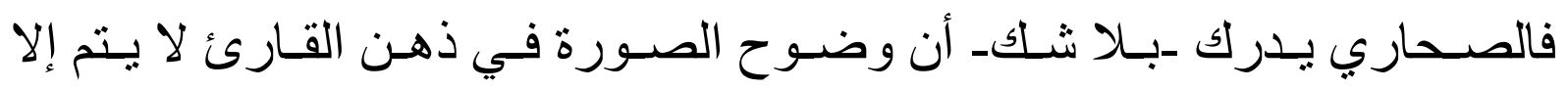

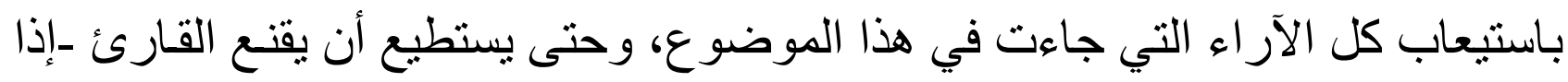

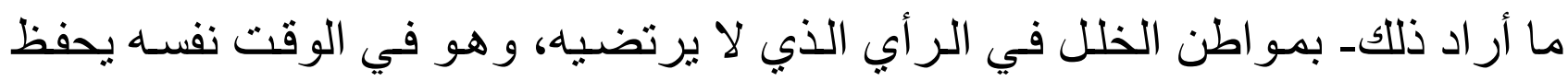

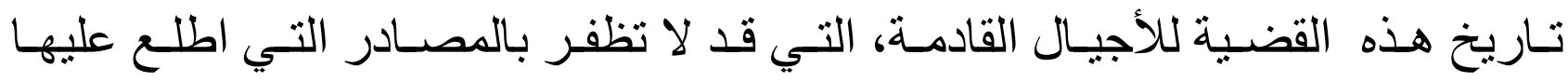

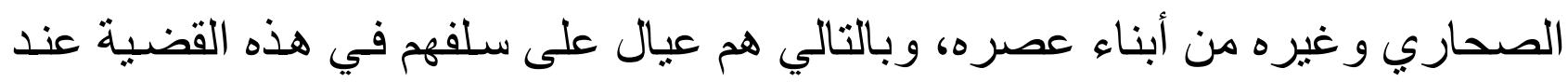

ومن أجمل صور النزا اهة عند علمـاء المسلمين في منهجهم النقدي، أنهم كانوا

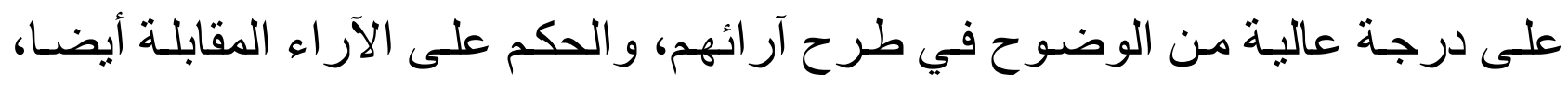
بغض النظر عن صحتها، فلم يجدوا حرجا في الاعتر اف بصو اب الر أب الآخر مهيا

$$
\begin{aligned}
& \text { (187) الفار ابي: التمرة المرضية، (صنية (صنية) . }
\end{aligned}
$$

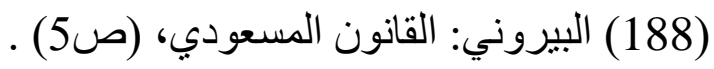

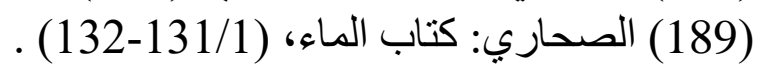

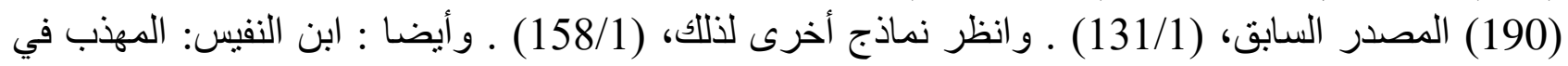

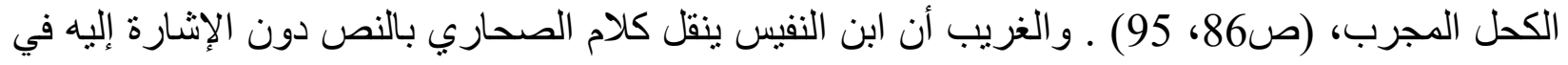
مناقشة للآر اء التي تناولت موضع الإبصار . 
كـان صـاحبه، (( و الحق مـا قالـه جـالينوس ) (191) ـ وأن آر ائهم و أقو الهم ليست حقيقة

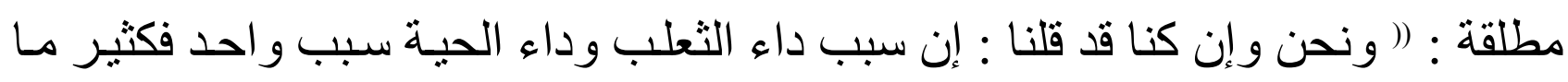

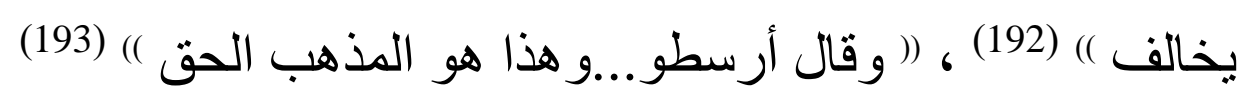

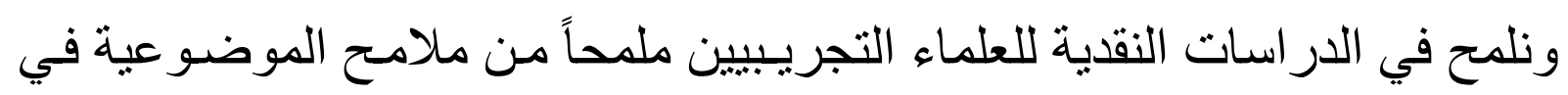

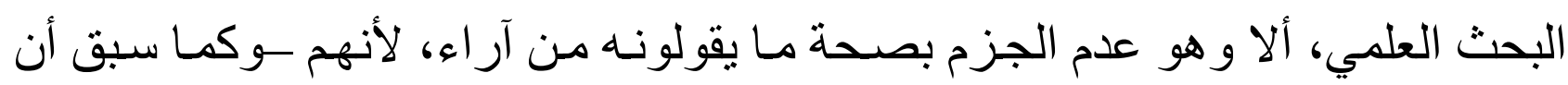

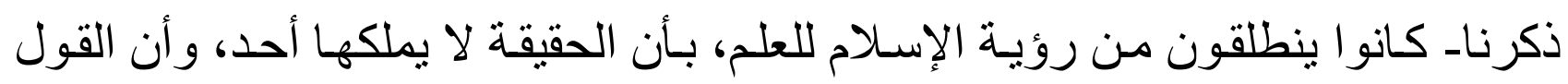

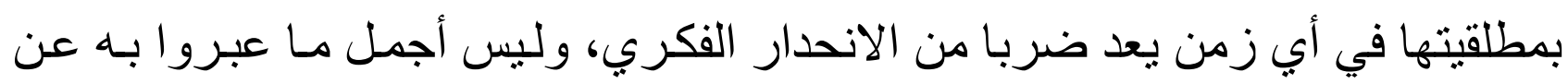

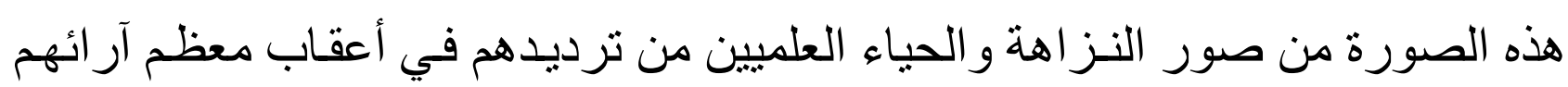

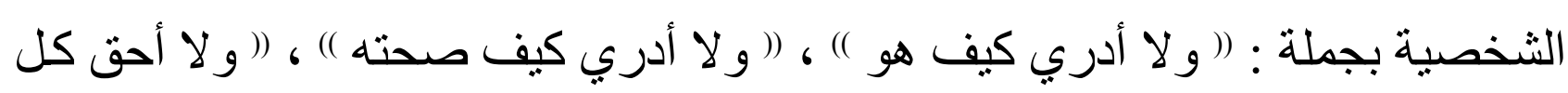
ذلك، و لا أعرف كيفيته ) (194)

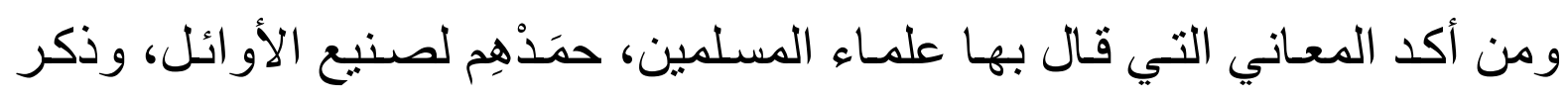

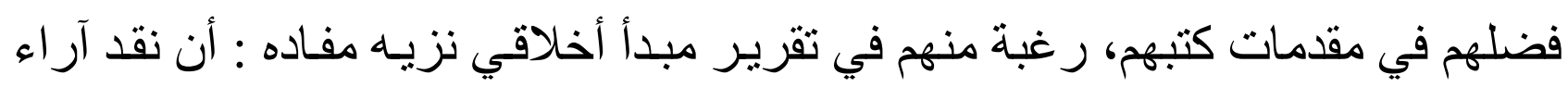

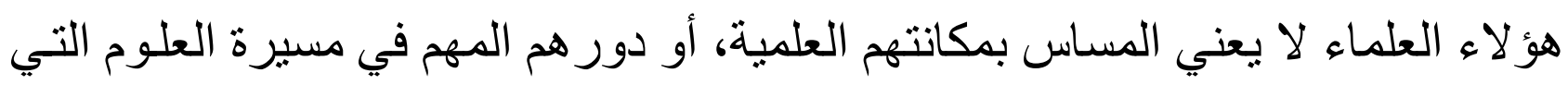

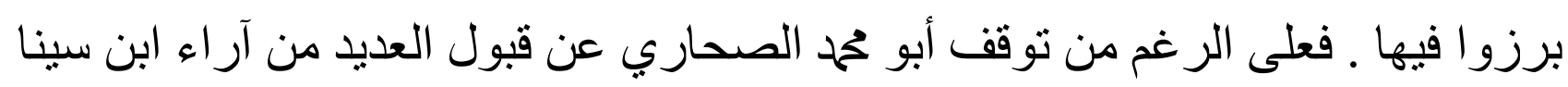

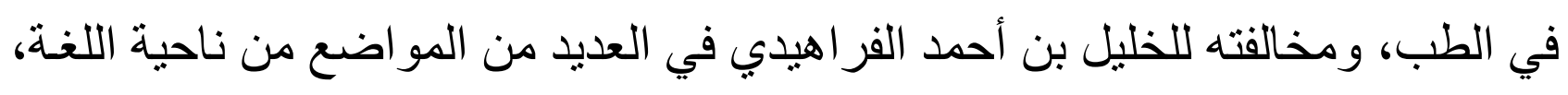

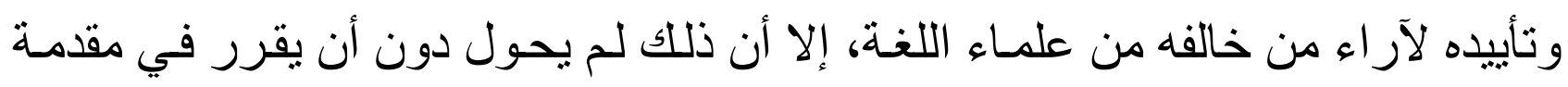

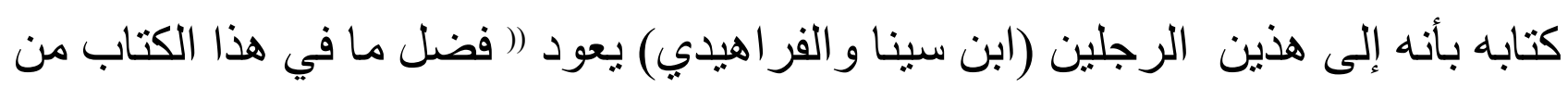

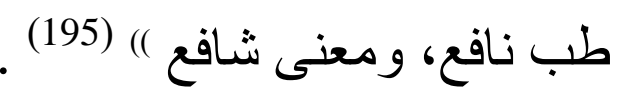

\section{2- الأمانة العلمية :}

إن من أهم السمات الأساسية و الحتمية التي يجب أن تتوفر في أي علم من العلوم

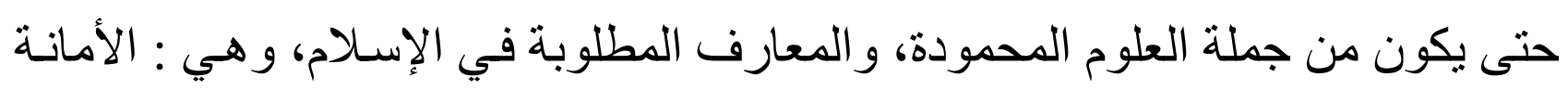

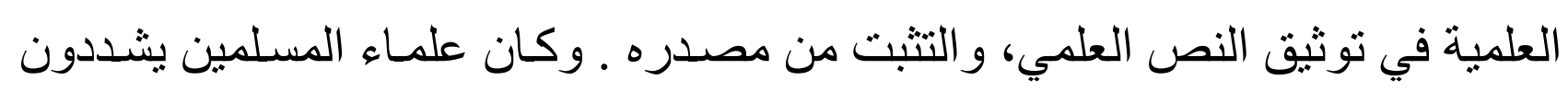

$$
\begin{aligned}
& \text { (191) ابن النفس: شرح فصول أبقر اط، (صا1127) ـ الكثكري: الكناش في الطب، (ص332) . }
\end{aligned}
$$

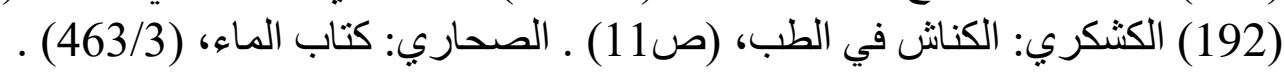

$$
\begin{aligned}
& \text { (193) الصحاري: كتاب الماء، (1921) (317/1) . } \\
& \text { (194) الصحاري: كتاب الماء، (193/28)، 297، 297، 326) . } \\
& \text { (195) (194) الصحاري: كتاب الماء، (31/1) . }
\end{aligned}
$$


على ضرورة الأمانة والدقة في النقل ـ وبغض النظر، سو اء أكان المنقول حقا أو باطلا،

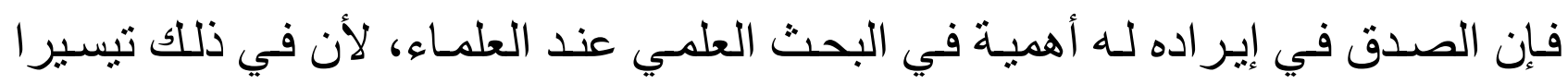
للطالب للاطلاع على الآر اء المختلفة حيال علم من العلوم، أو قضية من القضايا (196) .

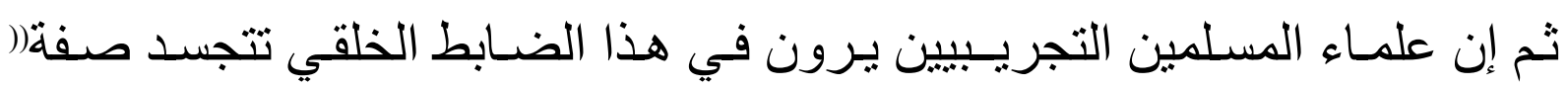

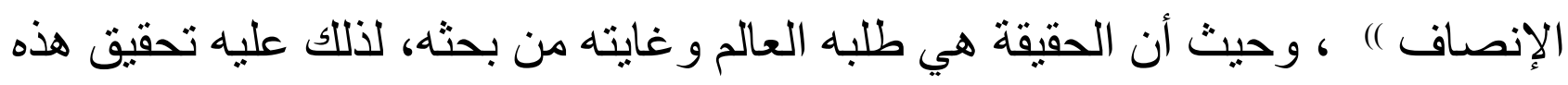

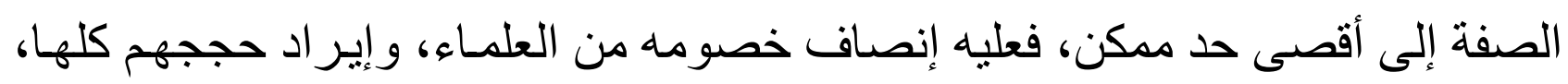

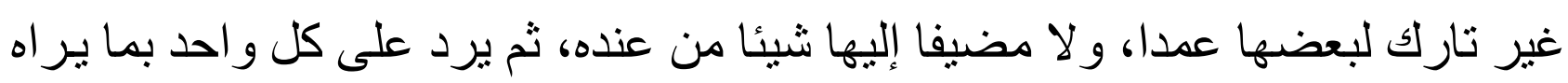

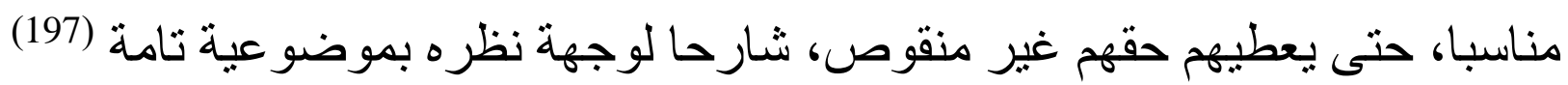

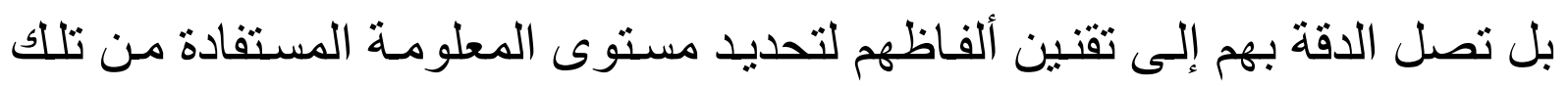

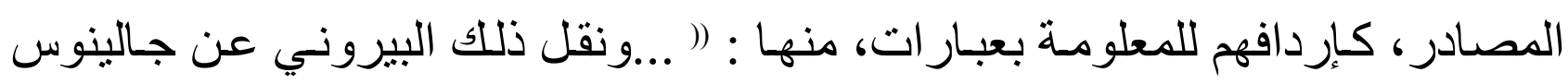

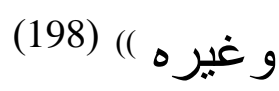

\section{الثاني : الضابط العلمي (الانسجام مع المنهج العلمي )}

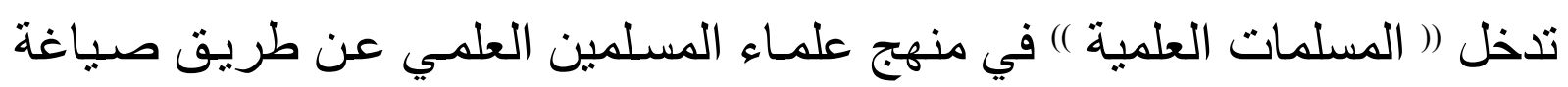

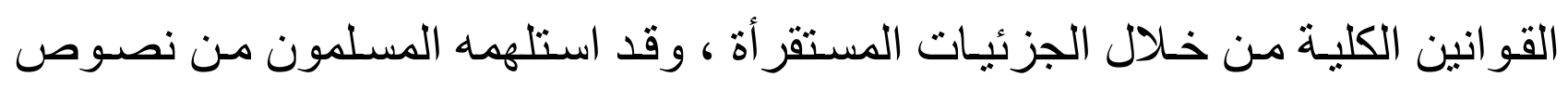

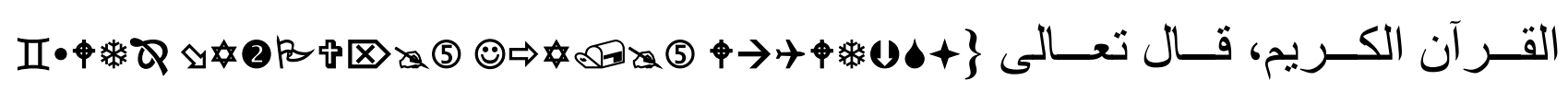

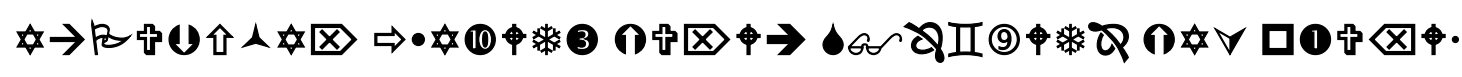
(3)

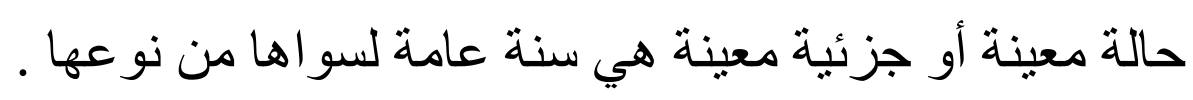

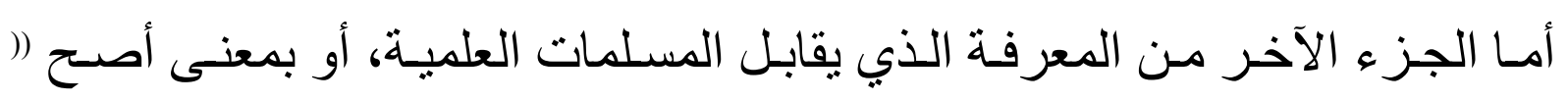

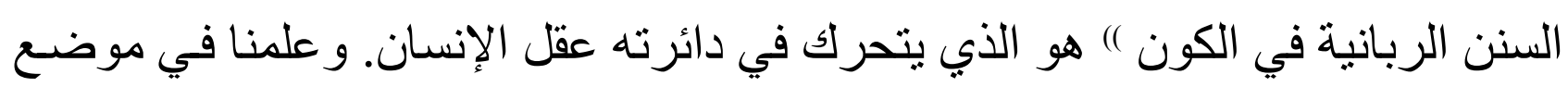

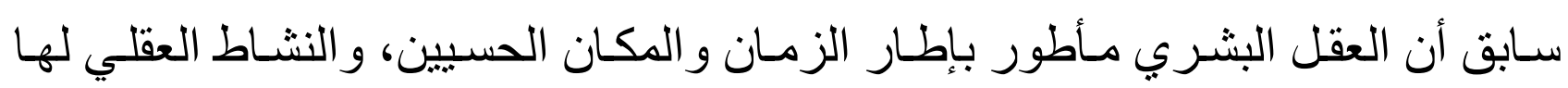

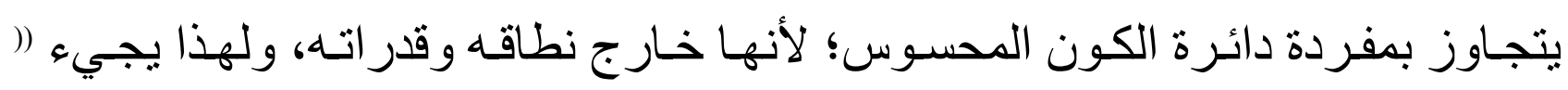

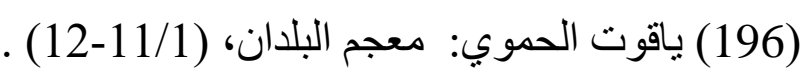

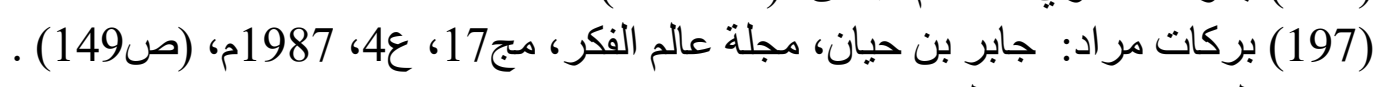

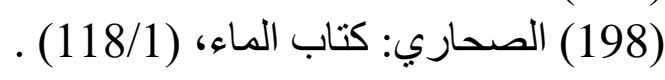

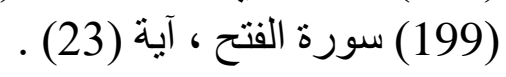


الوحي الإلهي ) ليكمل للإنسـان دائرة المعرفة فيخبره بما هو خارج قدر اتهه من عـالم

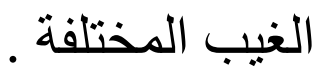

ولذلك نلاحظ أن تطبيق معيار الانسجام عند علمـاء المسلمين ارتبط بمدى توافقه مع المنهج العلمي، و أداتي العلم: الحس، و العقل. فيقول أحدهم: ( و والحس أقوى دلبيلاً من السمع .. وجالينوس و إن كان في الدرجة العليـا من التحري و التحفظ فيما يباثُره ويحكيه إلا أن الحس أصدق منه ) (200) و لاشك أن الارتكاز على هذا المعيار في سير الآراء العلمية ونقدها يتطلب التعليل

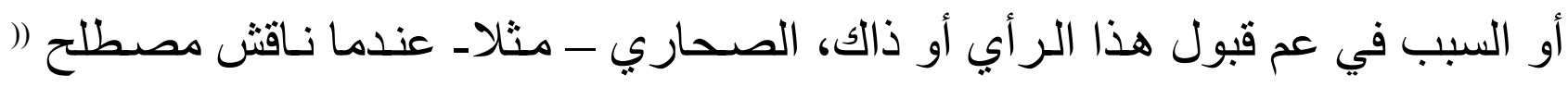

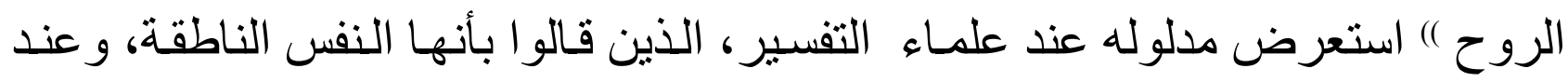
المتكلمين هي: جسم لطيف سار في البدن كسريان ماء الورد في الورد، ولفي وعند جمهور

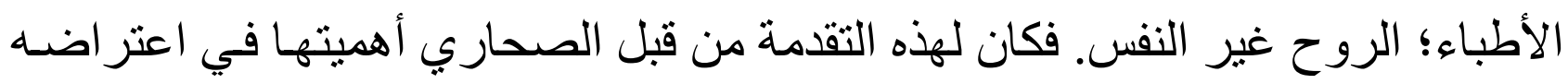

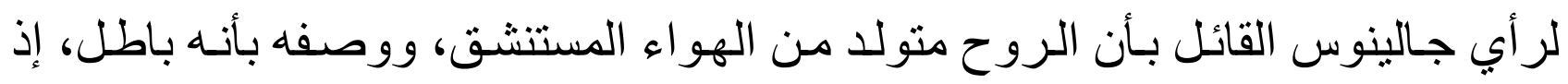

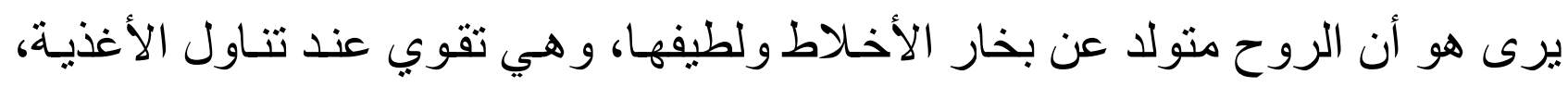

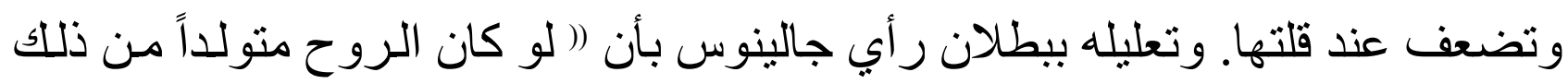

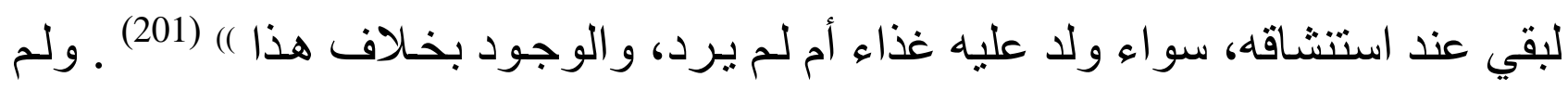
يقبل الجوهري صاحب ( الصحاح في اللغة ) )بأن مصدر الكافور دويبـة تشبه السينََّّد،

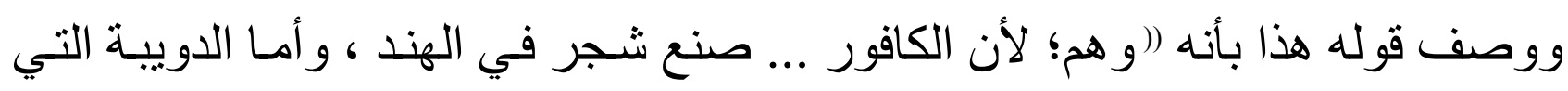

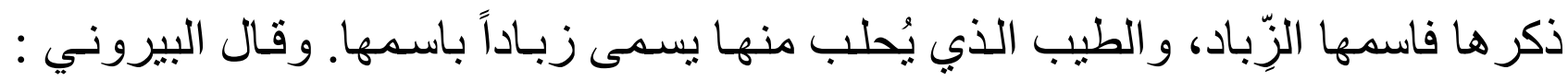
الكافور صمغ شجر يكون في داخل الثجر .... )، (202) إلا أن هذا التشدد في الاستمساك بضابط الانسجام حذو القذة بالقذة في العلاقة بين

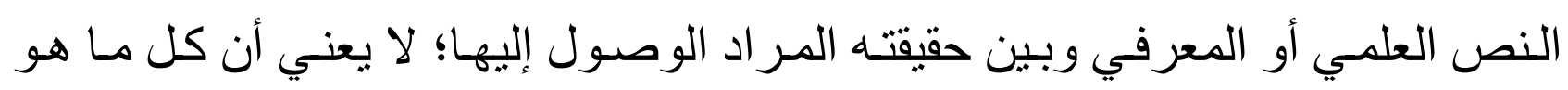

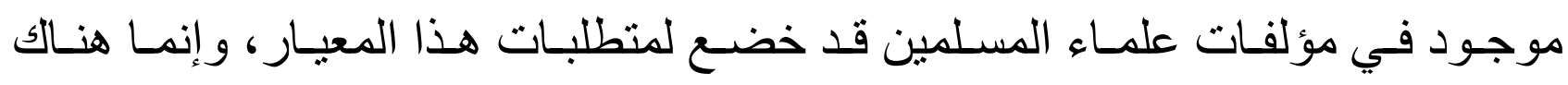

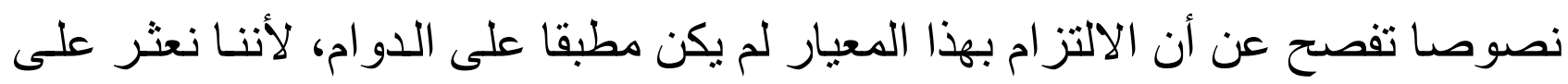

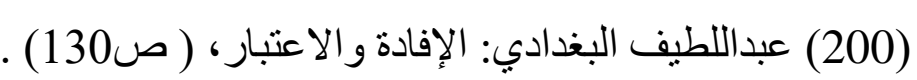

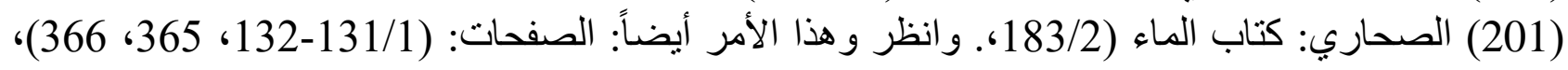
.

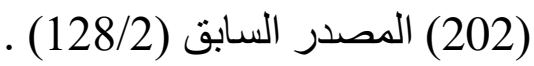




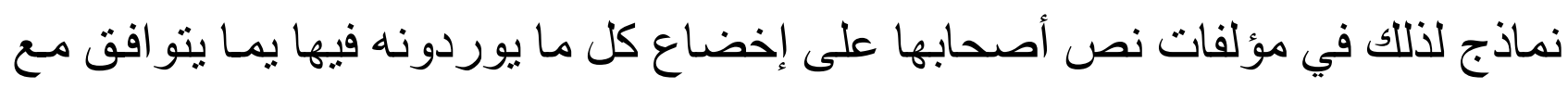

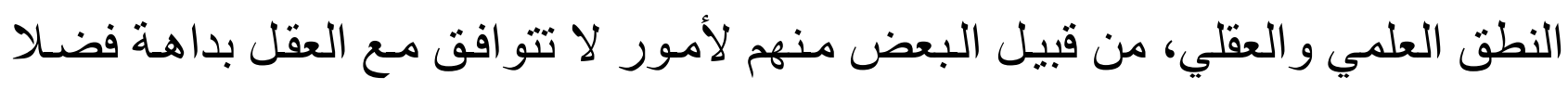

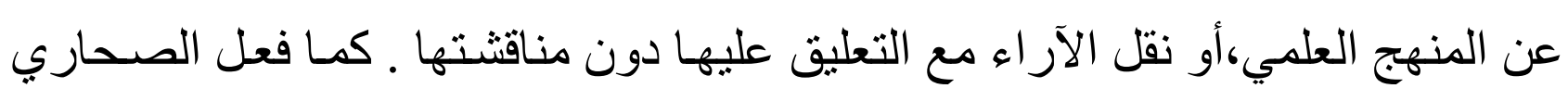

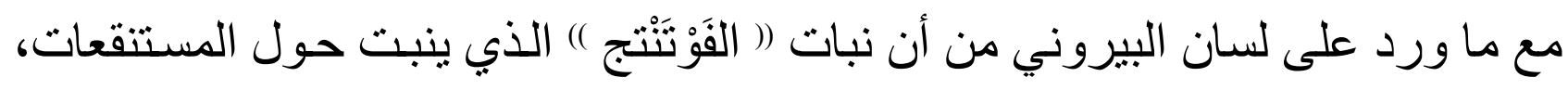

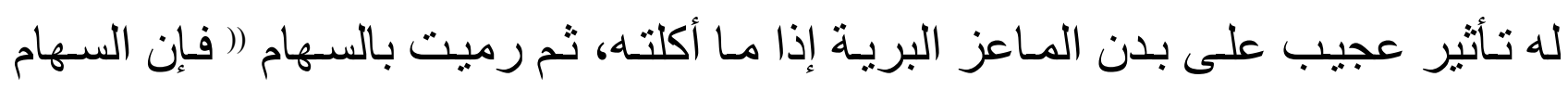

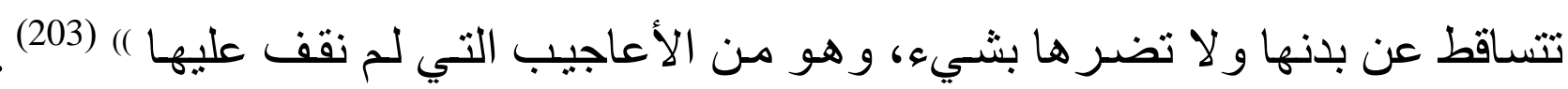

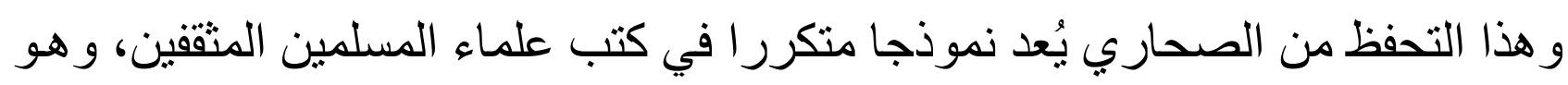

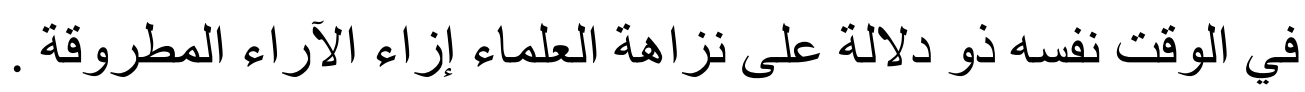

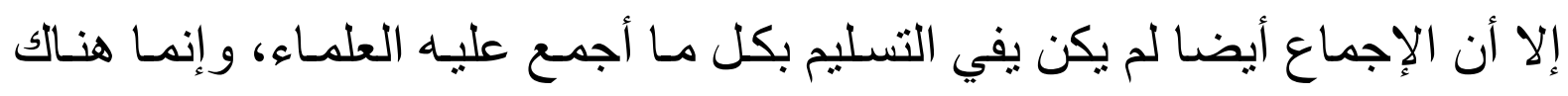

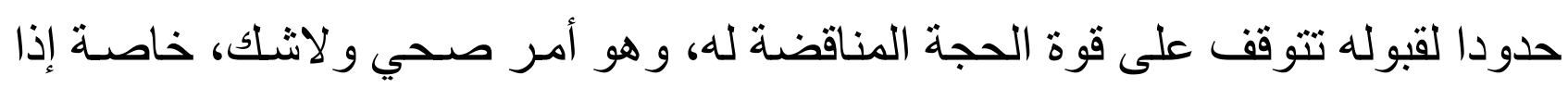

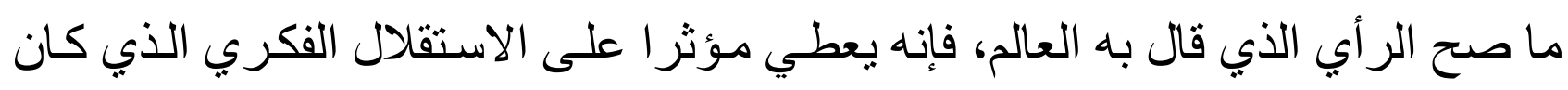

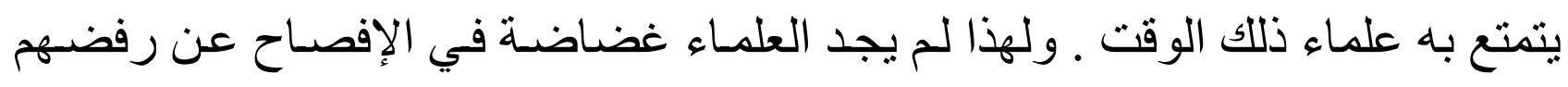

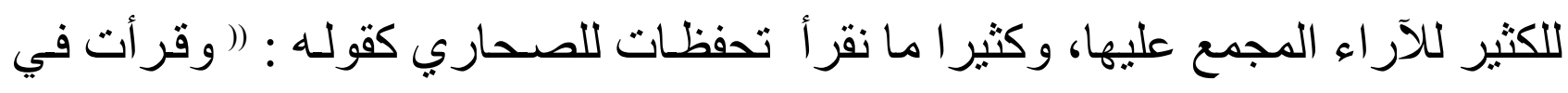

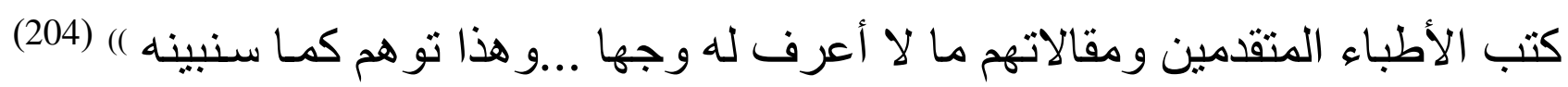

و إذا كانت التجربـة تمثنل عنصـر ا جو هريـا، وركيزة أساسية يقوم عليها المنهج

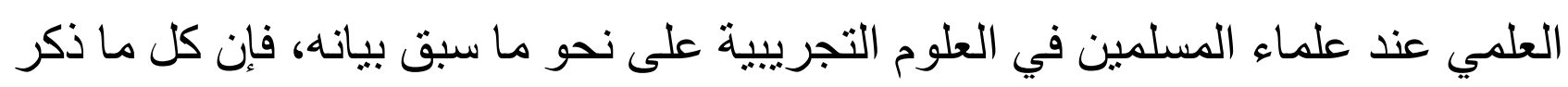

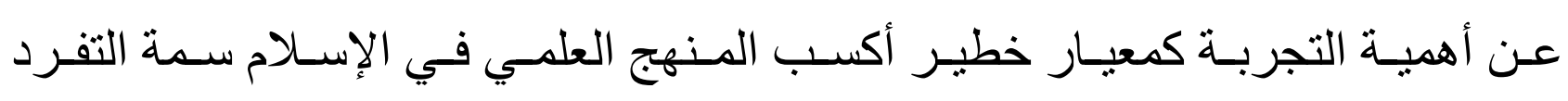

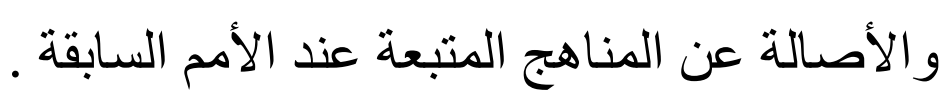

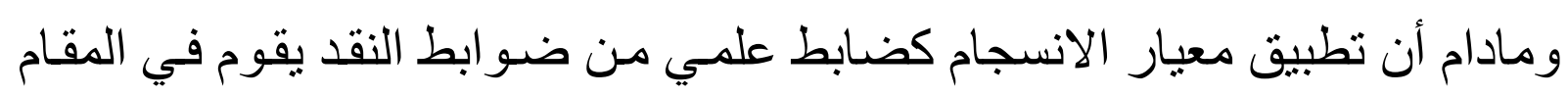

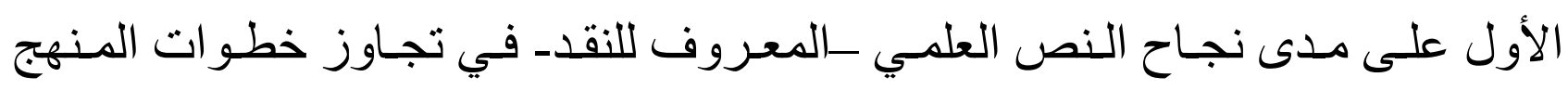

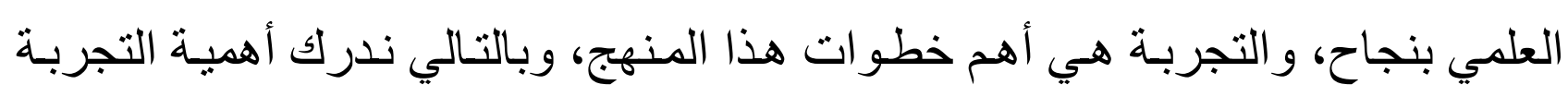

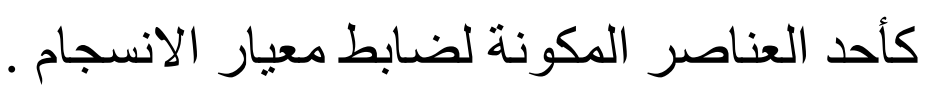


ولذللك، نقر أ نصوصـا صـريحة وحاسمة لعلمـاء المسلمين في إخضـاعهم لكل مـا

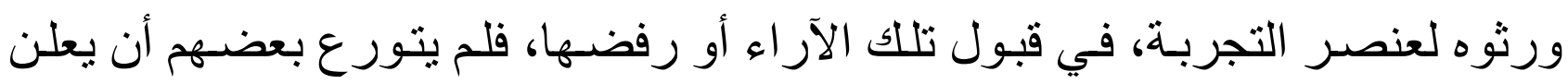
صر احة بعد تجربته لبعض النتائج التي وصلت إلبه ،"(و لا تلتقت إلى قول من يقول من

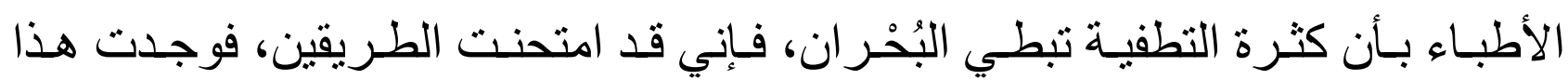

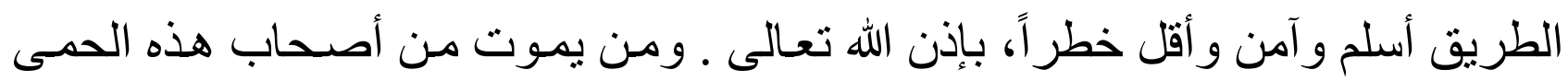

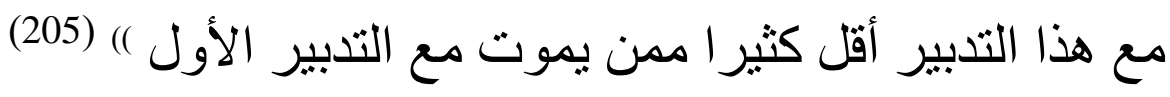
و هذا يعني أن الحواس، و إن كانت هي السبب الذي يؤدي إلى كل المعارف الحسية

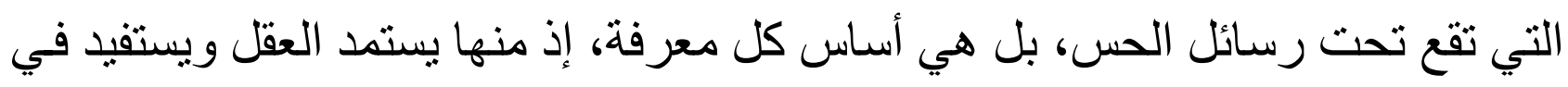
تكوين معـارف يقينية لا سبيل إلى الثـك فيها، نقول و إن كانت كذللك إلا أن سـلامتها الوظيفية، وانضباطها بما حدده الإسلام لمجالات العقل يمكن أن يكون ذلك جو هر معيار الانسجام بين الآر اء العلمية المطروقة على بساط البحث وبين المنطق العلمي و العقلي .

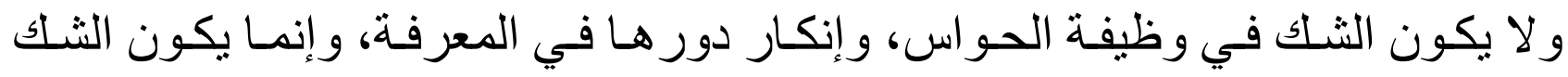

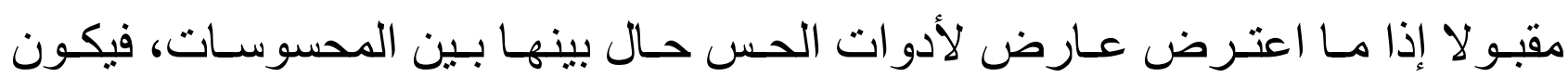

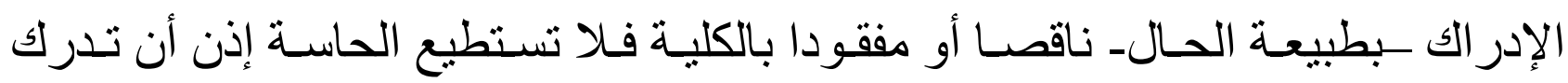

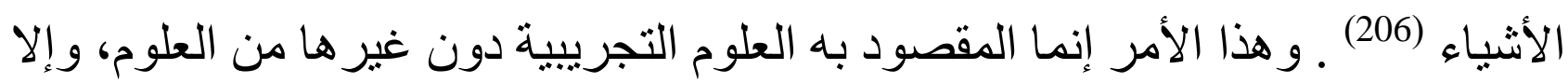

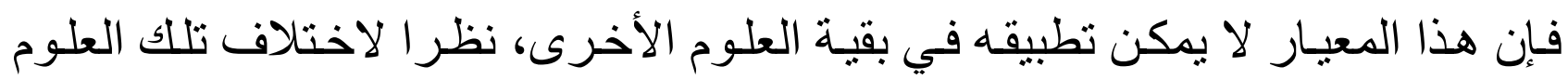
التجرييية ومن حيث العمل التقني في أكثر جو انبها، ومن حيث مصادر معرفتها .

\section{الخاتمة}

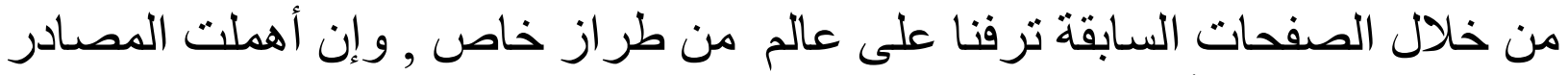

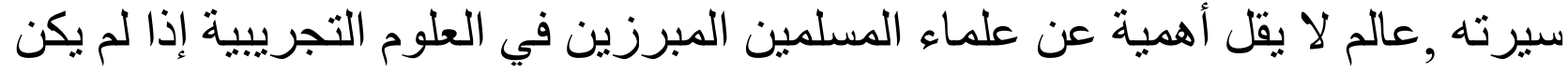

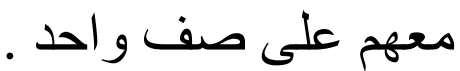

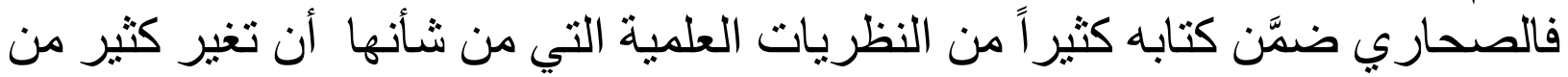

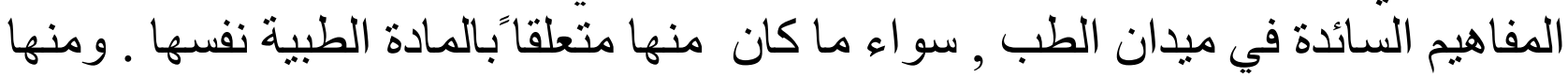

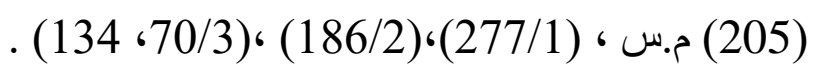

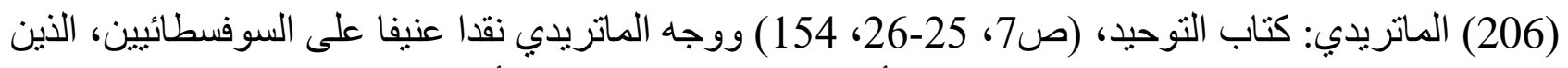

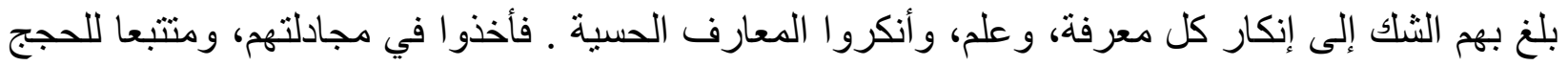

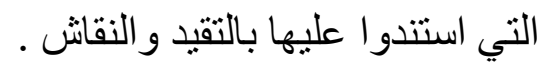


: أن الششهور في تاريخ العلوم أن ابن النفيس (ت 686هـ ) قد سبق العلماء الأوروبيين

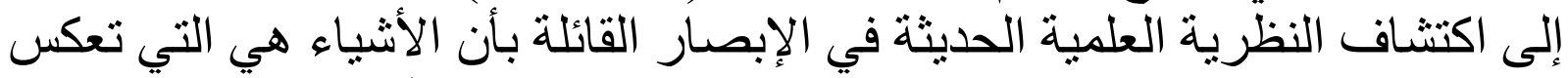

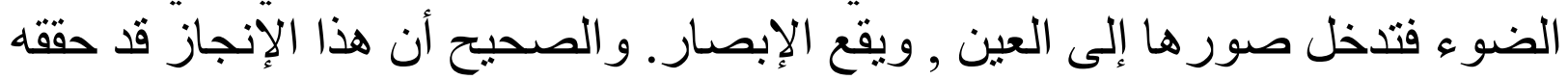

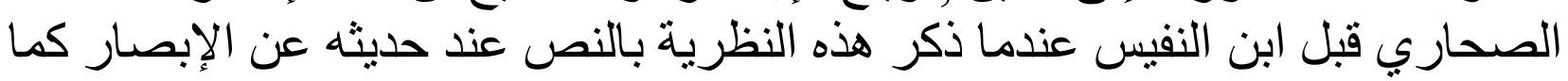

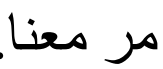
كما تطرق الصحاري إلى الأمر اض النفسية , والاضطر ابات العقلية وأوضح طرق

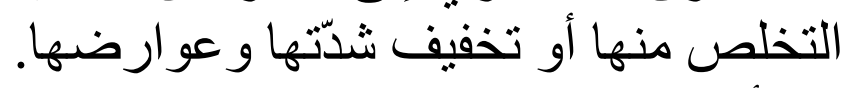

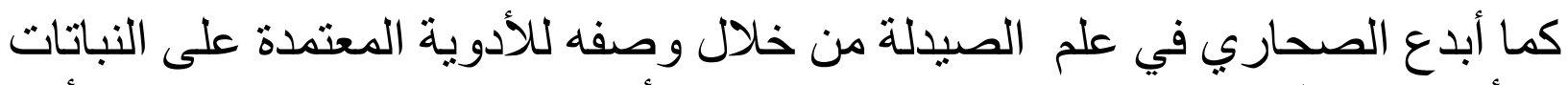

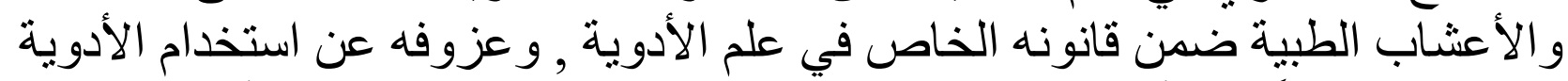

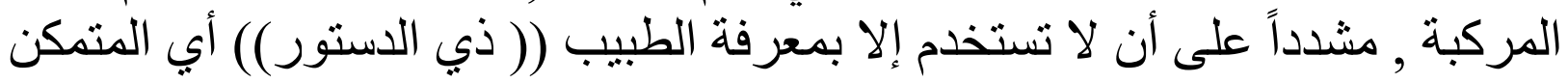

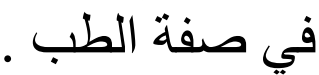
وأخير اً فإن كتاب الماء للصحاري يعد ذخيرة علمية يكفي الصحاري ـلولم يخرج سواء ـ شرفاً بأن صنف مثل هذا السفر العلمي العظيم.

\section{فهرس الموضو عات}

الصفحة

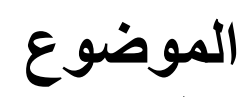

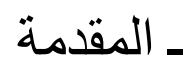

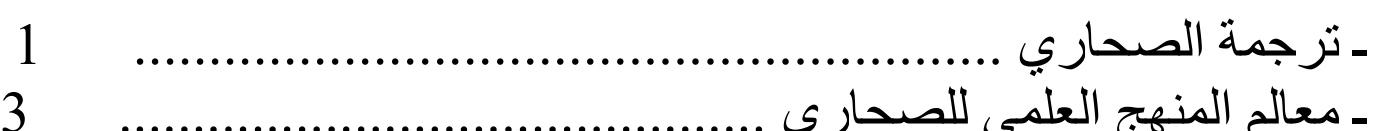

19

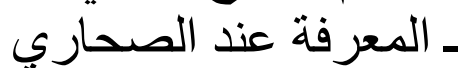

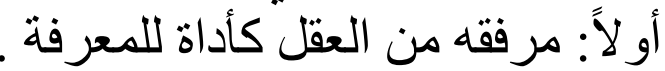




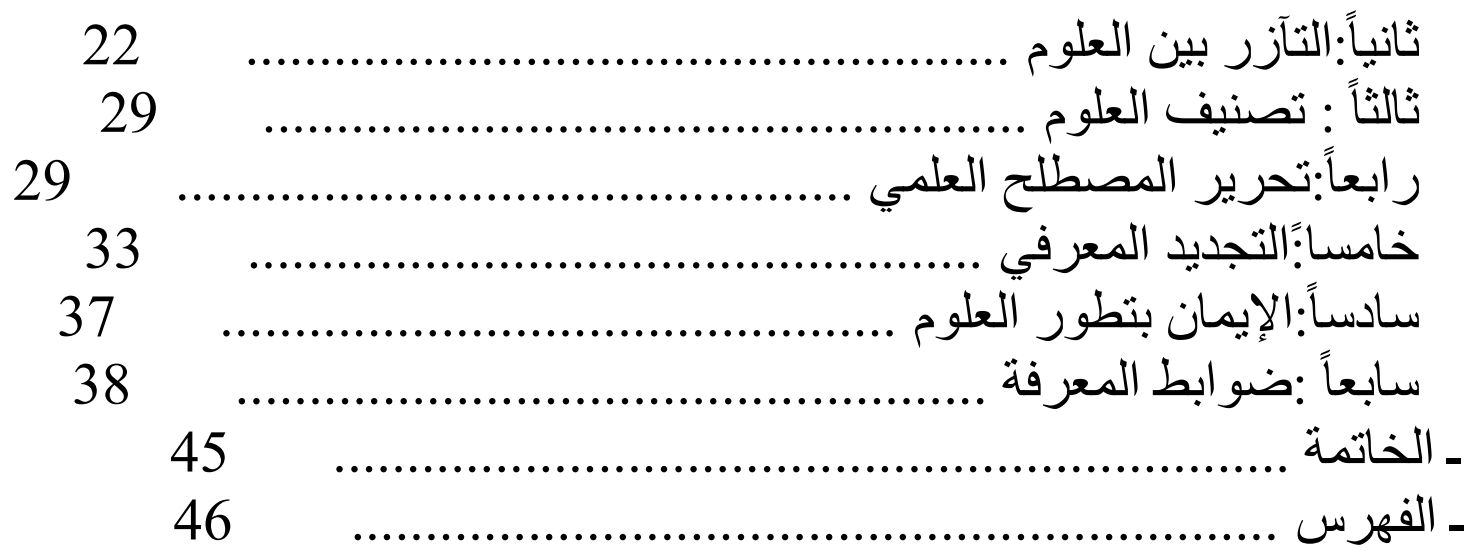

